Solange Aparecida Machado

\title{
Dinâmica dos arranjos produtivos locais: \\ um estudo de caso em Santa Gertrudes, a nova capital da cerâmica brasileira
}

Tese apresentada à Escola Politécnica da Universidade de São Paulo para obtenção do Título de Doutor em Engenharia de Produção

São Paulo 
Solange Aparecida Machado

\section{Dinâmica dos arranjos produtivos locais: \\ um estudo de caso em Santa Gertrudes, a nova capital da cerâmica brasileira}

Tese apresentada à Escola Politécnica da Universidade de São Paulo para obtenção do Título de Doutor em Engenharia de Produção

Orientador: Professor Dr. Guilherme Ary Plonski

São Paulo 
Machado, Solange Aparecida

Dinâmica de arranjos produtivos locais: um estudo de caso

em Santa Gertrudes, a nova capital da cerâmica brasileira

/ Solange Aparecida Machado. /

ed. rev. - São Paulo, 2003

$145 \mathrm{p}$.

Tese (Doutorado) - Escola Politécnica. Universidade de São Paulo.

1. Arranjos produtivos Locais 2. Santa Gertrudes 3. Cerâmica de revestimento I. Universidade de São Paulo. Escola Politécnica. Departamento de Engenharia de Produção II.t 
Data da defesa:28/07/2003

\section{BANCA EXAMINADORA}

Professor Doutor: Guilherme Ary Plonski

Julgamento:

Assinatura:

Professor Doutor: Afonso Carlos Fleury

Julgamento:

Assinatura:

Professor Doutor: João Amato Neto

Julgamento:

Assinatura:

Professor Doutor: Maria Carolina Souza

Julgamento:

Assinatura:

Professor Doutor: José Octavio Paschoal

Julgamento: Assinatura: 


\section{AGRADECIMENTOS}

Gostaria de agradecer às várias pessoas de diversas instituições, que tiveram participação na realização deste trabalho, principalmente da Escola Politécnica, do IPT e do setor cerâmico.

Ao professor Ary Plonski, que acompanhou minha carreira acadêmica desde o mestrado, sempre com intervenções fundamentais e precisas.

Ao professor Afonso Fleury, pelas sugestões na elaboração da metodologia.

Ao professor João Amato pela bibliografia que me introduziu no mundo dos APL's.

À Lídia e Ida pelas informações e agendamentos.

No IPT este trabalho foi debatido e compartilhado com vários pesquisadores, em diferentes fases e intensidades.

A meu querido amigo João Pizysieznig, pela discussão quase diária de conceitos, idéias e hipóteses.

Ao geólogo Chico Motta, em fazer o papel de especialista mais próximo e traduzir a linguagem da cerâmica de revestimento.

Aos pesquisadores Neusa Serra, Abraham Yu e Marsis Cabral, por participarem da elaboração dos questionários, dos diagnósticos de alguns elos da cadeia, das sugestões de políticas e da realização das entrevistas.

Às bibliotecárias Edna Gubitoso e Silvia Carneiro, pelo fornecimento de um dos principais insumos deste trabalho: a bibliografia.

Ao Diretor da DEES, Milton Campanário, pelo apoio institucional.

À Elvira e Sônia, pela paciência ao atendimento.

Aos meus amigos do IPT, Cristina, Agnes, Celso, Clayton, Eugênia, Barral, Nereide, Luciana, Eunice, Roque e Ana Lúcia, pela convivência prazerosa.

No setor de cerâmica devo agradecer, especialmente, ao professor Anselmo Boschi, ao pesquisador do IPEN e diretor do CCB, José Octavio Paschoal, à consultora catarinense Silene Seibel, ao diretor executivo do Sindicato da Indústria da 
Construção e Mobiliário de Santa Gertrudes, Marcelo Piva, e a todos os empresários e técnicos das empresas entrevistadas.

Aos meus pais, Lourdes e João e minhas irmãs, Regina e Ana, pelo apoio afetivo e financeiro.

Ao meu filho João, pela motivação e tempo roubado. 
Dedico este trabalho à nova geração da família Machado:

João Gabriel,

Mariana, Eduardo e André 


\section{SUMÁRIO}

1. INTRODUÇÃ $O$.............................................................................................................. 1

1.1 PERGUNTAS DE PARTIDA..........................................................................................................

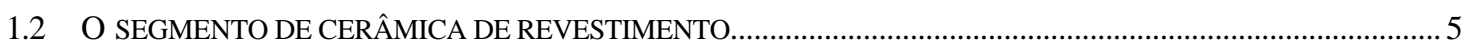

1.3 CONCENTRAÇÃO GEOGRÁFICA NO SEGMENTO PRODUTOR DE CERÂMICA DE REVESTIMENTO.................7

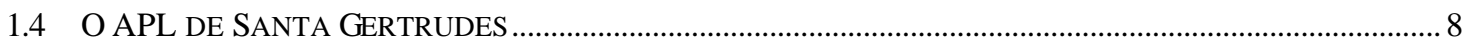

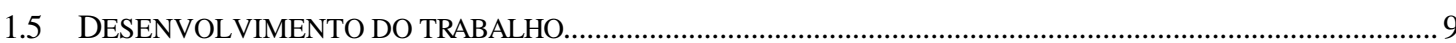

\section{DETERMINANTES DA CONCENTRAÇÃO GEOGRÁFICA DE EMPRESAS....... 10}

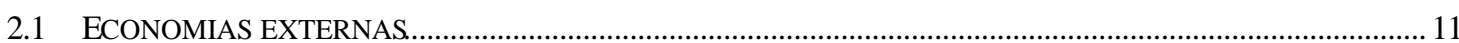

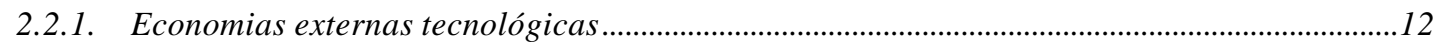

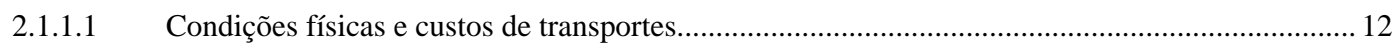

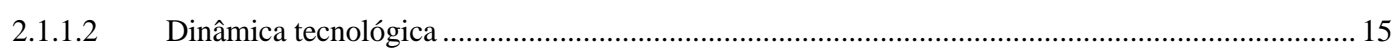

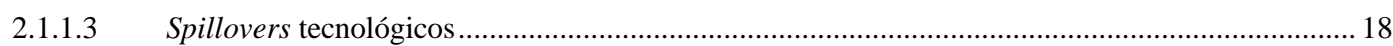

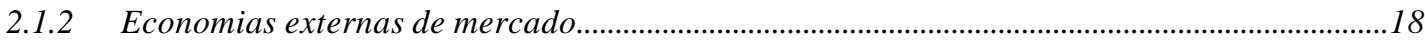

2.1.2.1 Variações espaciais da demanda e centralidade do produto......................................................... 18

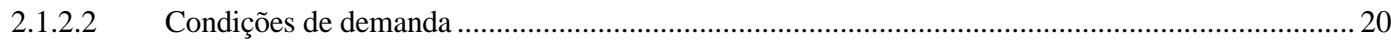

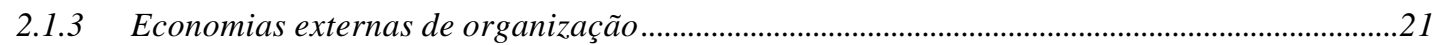

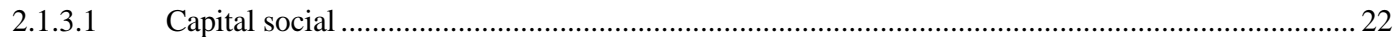

2.1.3.2 Capacitação da mão-de-obra e dos empresários.......................................................................... 32

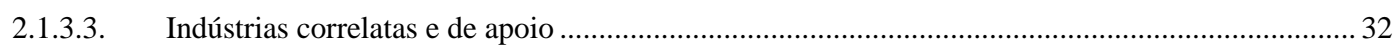

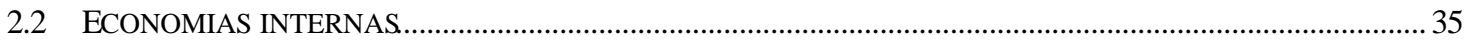

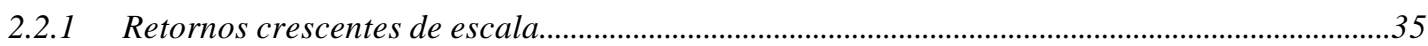

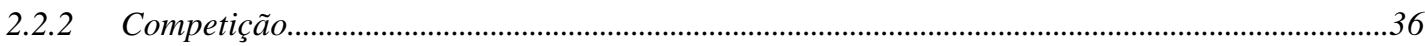

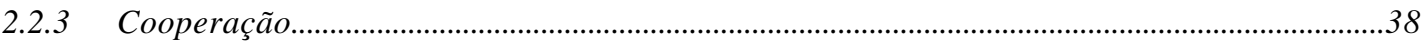

3. MODELO CONCEITUAL DE EVOLUÇÃO DOS APL'S...................................... 39

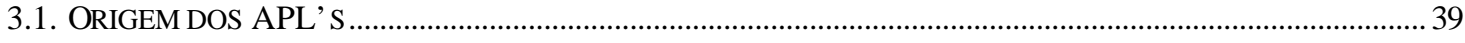

3.1.1 Economias de escala e concentração de empresas...................................................................41

3.1.2 Economias de escala e custos de transporte .....................................................................................44

3.1.3 Economias de escala e inovação revolucionária ..........................................................................44

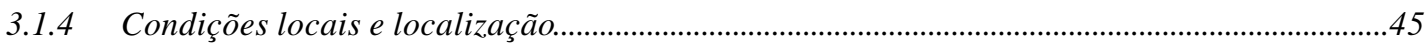

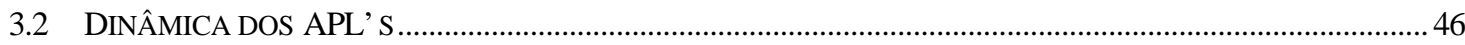

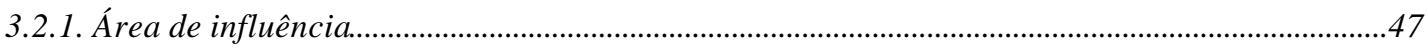

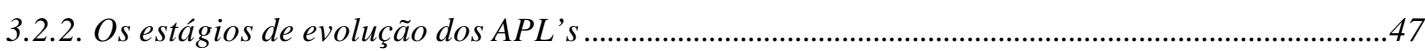

4. METODOLOGIA PROPOSTA PARA VALIDAÇÃO DO MODELO........................ 53 


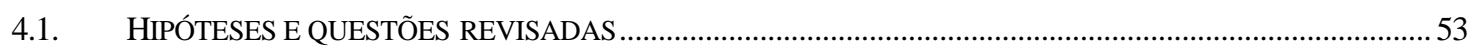

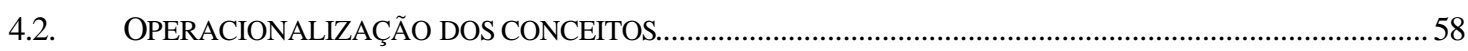

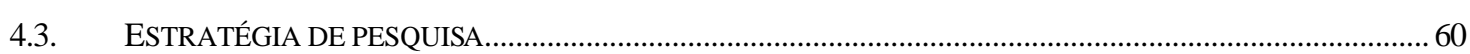

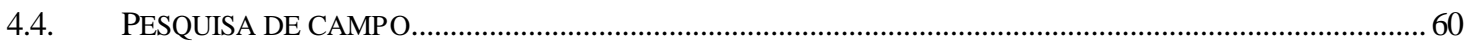

5. O SEGMENTO DE CERÂMICA DE REVESTIMENTO....................................... 62

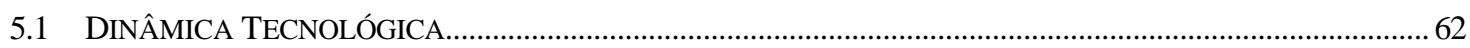

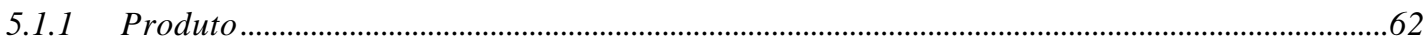

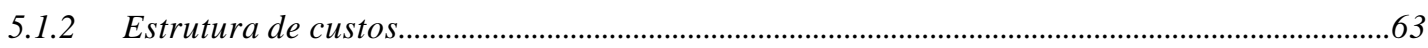

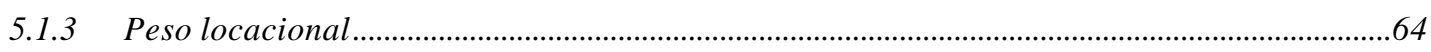

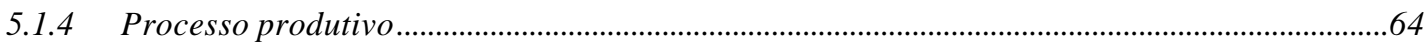

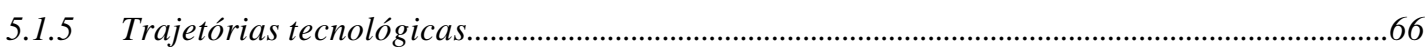

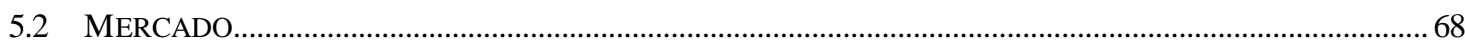

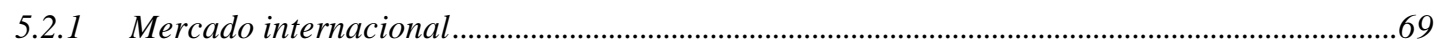

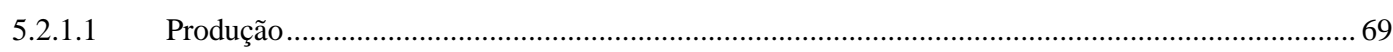

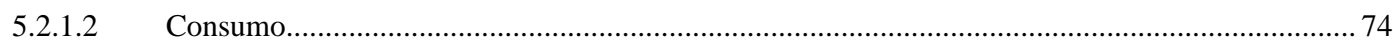

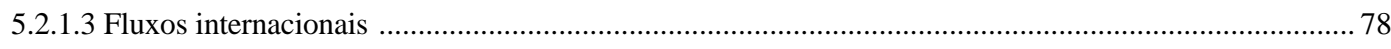

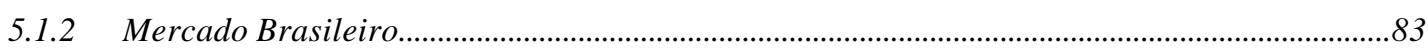

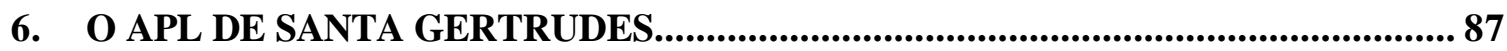

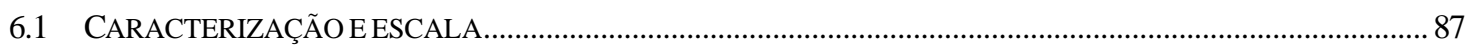

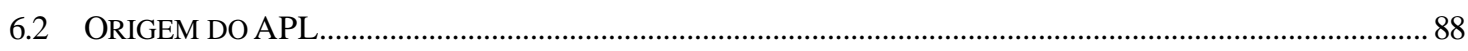

6.3 EMPRESAS CORRELATAS E DE APOIO - ELOS A MONTANTE.................................................................90

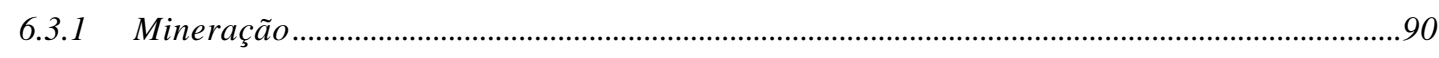

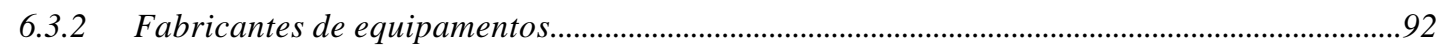

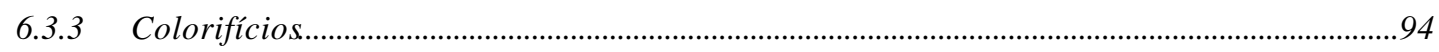

6.3.4 Instituições de Pesquisa, Ensino e Apoio............................................................................................98

6.4 EMPRESAS CORRELATAS E DE APOIO - ELOS A JUSANTE.........................................................................99

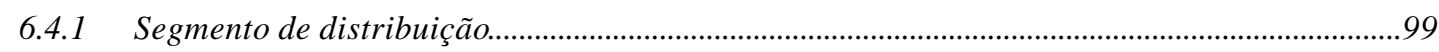

6.4.1.1 Extensão da rede de distribuição ................................................................................................. 99

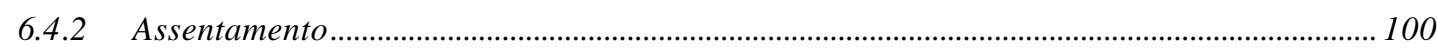

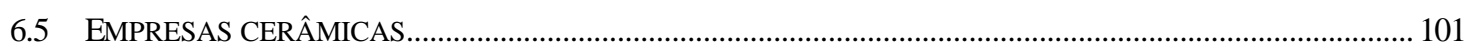

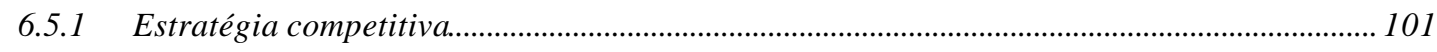

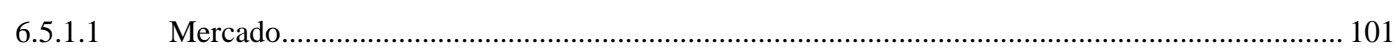

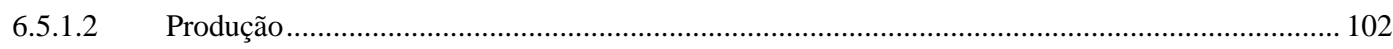

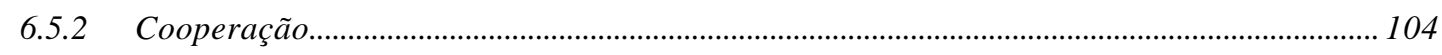

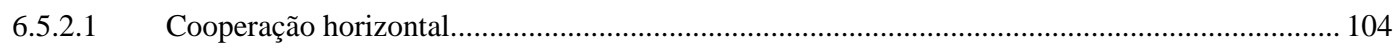

6.5.2.2. Cooperação vertical multilateral ................................................................................................... 105

6.5.2.3 Cooperação vertical bilateral a montante - fornecedores de matérias -primas ............................. 105

6.5.2.4. Cooperação vertical bilateral a montante - fornecedores de equipamentos ............................... 106 
6.5.2.5 Cooperação vertical bilateral a montante - colorifícios ............................................................ 107

6.5.2.6 Cooperação vertical bilateral a montante: instituições de pesquisa.............................................. 108

6.5.2.7 Cooperação horizontal bilateral a jusante: distribuidores e agentes de comercialização.............. 109

6.5.2.8 Cooperação horizontal bilateral a jusante: exportação .............................................................. 110

6.5.2.9 Cooperação horizontal bilateral a jusante: serviços pós-venda.................................................. 110

7. VALIDAÇÃO DO MODELO CONCEITUAL................................................................ 112

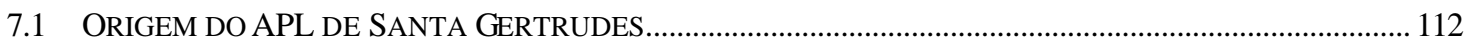

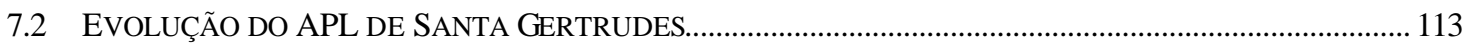

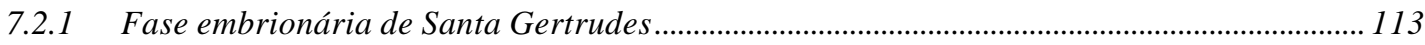

7.2.2 Fase de crescimento de Santa Gertrudes................................................................................... 114

7.3 Maturidade de Santa Gertrudes................................................................................................... 115

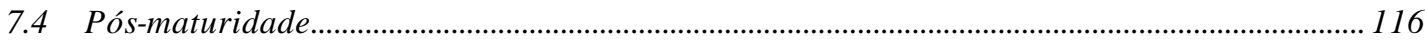

8. CONCLUSÕES E RECOMENDAÇÕES.................................................................. 117

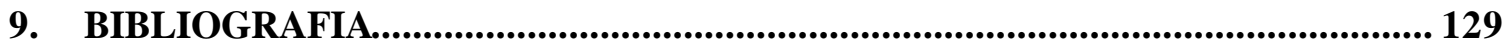




\section{ÍNDICES DE FIGURAS}

Figura 1 - Cadeia produtiva de revestimentos cerâmicos........................................... 6

Figura 2 - Determinantes da concentração geográfica de empresas ..........................11

Figura 3 - Modelo conceitual de evolução dos APL's.......................................................40

Figura 4 - Premissas (P), Questões (Q), Hipóteses (H) e Resultados (R)................... 57

Figura 5 - Estrutura genérica dos custos de produção em Santa Gertrudes................ 64

Figura 7 - Evolução da produção mundial de cerâmica de revestimento. ...................... 71

Figura 8 - Taxas geométricas de crescimento da produção mundial de cerâmica de

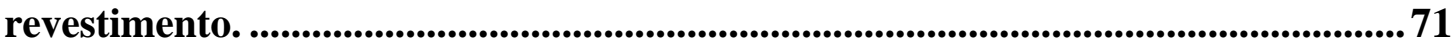

Figura 9 - Evolução da produção mundial de cerâmica de revestimento por país..... 71

Figura 10 - Participação dos países na produção mundial de cerâmica de revestimento.

Figura 11 - Taxas geométricas anuais de crescimento da produção (96/2001). ........... 73

Figura 12 - Taxa de evolução da produção de cerâmica na década de 90 ..................... 73

Figura 13 - Evolução do consumo mundial de cerâmica de revestimento...................... 75

Figura 14 - Evolução do consumo mundial por país.................................................................. 76

Figura 15 - Participação no consumo mundial (2001) ....................................................... 76

Figura 16 - Taxas geométricas de crescimento do consumo (98/2001)............................ 77

Figura 17 - Consumo per capita de cerâmica de revestimento (1999). ........................... 77

Figura 18 - Evolução do consumo médio per capita no mundo......................................... 78

Figura 19 - Evolução das exportações mundiais (98/2001). ................................................ 79

Figura 20 - Principais países exportadores de cerâmica de revestimento..................... 80

Figura 21 - Participação dos países na exportação em 2001 ...........................................80

Figura 22 - Taxa geométrica de crescimento das exportações (98/2001)........................81

Figura 23 - Participação das exportações na produção dos principais países

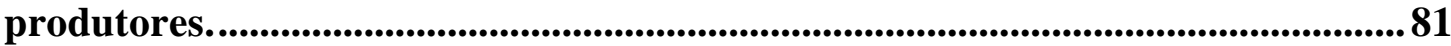

Figura 24 - Principais importadores de cerâmica de revestimento...............................82

Figura 25 - Participação dos principais importadores no total de importações mundiais.

Figura 26 - Cotas de consumo e produção de cada região sobre a produção mundial em 2000.

Figura 27 - Evolução da produção brasileira de cerâmica de revestimento. 
Figura 28 - Taxa geométrica de crescimento da produção. ...........................................85

Figura 29 - Distribuição regional da Cerâmica de revestimento no Brasil. ................... 85

Figura 30 - Destino das exportações brasileiras..................................................................86

Figura 31 - Origem das exportações brasileiras por região. ..........................................86

ÍNDICES DE QUADROS E TABELA

Quadro 1 - Sanções e confiança (baseado em: HUNPHREY \& SCHMITZ, 1998) .........31

Quadro 2 - Formas de cooperação nos aglomerados ......................................................... 38

Quadro 3 - Classificação das variáveis x questões de pesquisa.......................................59

Quadro 4 - Entrevistas realizadas para a pesquisa de campo ........................................... 61

Tabela 1 - Tipologia de placas cerâmicas quanto a absorção de água, carga e módulo de ruptura (ABNT 1997)...........................................................................................................................663 
MACHADO, S.A. Dinâmica dos Arranjos Produtivos Locais: um estudo de caso em Santa Gertrudes: a nova capital da cerâmica brasileira. 2003145 p. Tese (Doutorado) - Escola Politécnica, Universidade de São Paulo, São Paulo, 2003.

\section{RESUMO}

O objetivo deste trabalho é compreender a interação entre concentração geográfica de empresas, competitividade e tecnologia em Santa Gertrudes, pólo produtor de cerâmica de revestimento no estado de São Paulo. Utiliza-se o conceito de Arranjo Produtivo Local - APL, definido como concentração geográfica de empresas em determinado setor, inclusive fornecedores de insumos e serviços e que apresenta grau variável de interação entre os agentes.

É apresentado modelo para explicar o surgimento e desenvolvimento dos APL's, procurando validá-lo ao APL de Santa Gertrudes. A principal hipótese do modelo é de que uma inovação revolucionária no processo, combinada às condições locais específicas, pode originar novo APL. Após seu nascimento, o APL apresenta ciclo que passa pelas fases embrionária, crescimento, maturidade e pós-maturidade ou declínio, cada uma com padrões competitivos distintos.

A principal contribuição dessa tese foi a constatação de que o APL de Santa Gertrudes teve trajetória evolutiva bastante ajustada às previsões do modelo, de acordo com a dinâmica das inovações no processo produtivo. No momento, o APL está atravessando o turning point da fase de crescimento para a fase de maturidade.

A origem do agrupamento, no início dos anos 70, é creditada à adoção de paradigma de produção alternativo - a moagem via seca - que em condições locais específicas, como oferta de matéria-prima e capacitação em setor correlato - cerâmica vermelha - criou economias de escala extraordinárias e permitiu às empresas de Santa Gertrudes competirem com estratégia de baixos custos. No final dos anos 80, uma série de inovações reforçou as economias de escalas, iniciando a fase de crescimento. Atualmente, observa-se que o APL atingiu o limite da competição por custos e está entrando em uma fase de maturidade. Nessa nova fase, as empresas do APL necessitam de outras capacitações para esse novo padrão competitivo.

Palavra chave: Arranjos Produtivos Locais, cerâmica de revestimento, Santa Gertrudes 
MACHADO, S.A. Dynamics of local clusters: a case study in Santa Gertrudes: the new Brazilian capital of ceramic tiles. 2003145 p. Tese (Doutorado) - Escola Politécnica, Universidade de São Paulo, São Paulo, 2003.

\begin{abstract}
The objective of this thesis is to understand the interaction among geographic concentration of enterprises, competitiveness and technology for Santa Gertrudes, ceramic tiles cluster in São Paulo State, Brazil.

A cluster is defined as a geographic concentration of firms in an industrial sector, which includes inputs and services suppliers, showing different degrees of interaction among agents.
\end{abstract}

A model to explain the birth and development of clusters is proposed and validated for Santa Gertrudes cluster. The main hypothesis is that a revolutionary innovation, combined with specific local conditions, can originate a new cluster. A cluster presents an evolutionary cycle that encompasses embryonic, growing, maturity and after maturity phases, each one with distinctive competitive patterns.

The key contribution of this work is the realization that Santa Gertrudes cluster had an evolutionary trajectory as predicted from the model, according to the dynamics of production process paradigms adopted. Nowadays the cluster is passing through the turning point from the growing phase to the maturity phase.

The cluster was born at the beginnings of 70's due to the adoption of an alternative production paradigm - the dry mixture -, which combined with specific bcal conditions as raw material supply and competencies in a related sector - roof tiles and bricks created extraordinary economies of scale which enabled the Santa Gertrudes firms to compete with low cost strategy. At the end of the 80's, a series of innovations enlarged the economies of scale, beginning the cluster growing phase. At present it is observed that the cluster had reached the limit of low cost competition and is going through the maturity phase. In this new phase the firms of Santa Gertrudes cluster need other competencies to face this new competitive pattern.

Key word: Local clusters, ceramics tiles, Santa Gertrudes 


\section{SIGLAS E ABREVIATURA}

ABC - Associação Brasileira de Cerâmica.

ANAMACO - Associação Nacional dos Fabricantes de Materiais de Construção.

ANFACER - Associação Nacional dos Fabricantes de Cerâmica de Revestimento.

APL - Arranjo Produtivo Local.

ASCER - Associação dos produtores de cerâmica de revestimento da Espanha.

ASPACER - Associação Paulista de Cerâmica de Revestimento.

ASTROPIASTRELLE - Associação dos Produtores de Cerâmica da Itália.

BNDES - Banco Nacional de Desenvolvimento Econômico e Social.

CBB - Centro Cerâmico do Brasil.

CCDM - Centro de Caracterização e Desenvolvimento de Materiais da Universidade Federal de São Carlos - UFSCar, com participação da Universidade Estadual Paulista - UNESP.

CETESB - Companhia de Tecnologia de Saneamento Ambiental, ligada à Secretaria do Meio Ambiente do Governo de São Paulo.

CIESP - Centro das Indústrias do Estado de São Paulo.

CITEC - Centro de Inovação Tecnológica em Cerâmica de Revestimento.

CTCCA - Centro para Couro, Calçados e Afins.

ECCIB - Estudo da Competitividade de Cadeias Integradas Brasileiras, estudo realizado sob a coordenação do NEIT - Núcleo de Economia Industrial e da Tecnologia do IE - Instituto de Economia da UNICAMP - Universidade de Campinas.

FENAC - Feira Nacional de Calçados de Novo Hamburgo.

FINAME - Programa do Banco Nacional de Desenvolvimento Econômico e Social BNDES para financiamentos, sem limite de valor, para aquisição isolada de máquinas e equipamentos novos, de fabricação nacional. 
FINEP - Financiadora de Estudos e Projetos MCT - Ministério de Ciência e Tecnologia.

IBGE - Instituto Brasileiro de Geografia e Estatística.

IPT - Instituto de Pesquisas Tecnológicas do Estado de São Paulo S/A.

MCT - Ministério de Ciência e Tecnologia.

PL - Peso Locacional

PROFORMA - Programa de Formação de Mão-de-Obra da ANFACER.

SCTDET - Secretaria de Ciência, Tecnologia, Desenvolvimento e Turismo do Estado de São Paulo.

SEBRAE - Serviço Brasileiro de Apoio às Micro e Pequenas Empresas.

SENAI - Serviço Nacional de Aprendizagem Industrial.

SINDICERAM - Sindicato das Indústrias de Cerâmica para Construção e de Olaria de Criciúma.

SINDUSCON - Sindicato das Indústrias de Construção Civil no Estado de São Paulo

UFSCar - Universidade Federal de São Carlos.

UNESP - Universidade Estadual Paulista Júlio de Mesquita Filho. 


\section{INTRODUÇÃO}

O objetivo deste trabalho é compreender o fenômeno da concentração geográfica de empresas e de que forma a dinâmica tecnológica interfere em sua competitividade. Para tal, parte-se de duas premissas básicas. A primeira é que existem determinados setores que apresentam tendência à concentração geográfica de empresas. A segunda premissa, derivada da primeira, é que existem vantagens competitivas nas concentrações geográficas de empresas.

O sucesso social e econômico de diversos agrupamentos de empresas no mundo, como os da Itália, França, Espanha, Alemanha, EUA e países do terceiro mundo motivou a retomada da discussão sobre o papel da concentração geográfica na competitividade das empresas. O exemplo mais destacado é o da chamada Terceira Itália, região central do país, onde se desenvolveu uma série de exemplos bem sucedidos de pequenas empresas concentradas geograficamente, voltadas à produção de bens de consumo, diferindo da produção fordista. Os distritos de Brenta e Marsha, produtores de calçados, e Sassuollo, produtor de cerâmica de revestimento, são casos típicos, com características comuns. Entre essas características se destaca: concentração de pequenas empresas (entre 300 e 500), especializadas em várias fases do processo produtivo, com ênfase em inovação e design, indústrias de máquinas e equipamentos com competitividade internacional, intensa cooperação vertical (do tipo cliente/fornecedor), alguma cooperação horizontal (entre as empresas concorrentes), ênfase na exportação e agente que coordena a cadeia de produção. Outros exemplos de sucesso apareceram na Europa, inicialmente na Alemanha e na França e, recentemente, na Espanha e Portugal. Algumas características nos demais casos europeus diferem do italiano, tais como o grau de envolvimento do governo e o tamanho das empresas. Nos EUA, o caso mais conhecido é o Vale do Silício, na Califórnia, região especializada na produção de bens com base em micro-eletrônica.

No Brasil, os exemplos do Vale dos Sinos, produtor de calçados femininos no Rio Grande do Sul, e o de cerâmica de revestimentos, em Criciúma, Santa Catarina, são dois casos típicos que já foram objeto de estudo na literatura internacional. 
No Estado de São Paulo, vários exemplos podem ser observados, como o pólo têxtil de Americana, couro-calçadista, em Franca e Birigui, cerâmica de revestimento em Santa Gertrudes e móveis em Votuporanga.

Diversos autores estudaram o fenômeno da concentração geográfica de empresas, propondo diferentes denominações, sendo as mais comuns: cluster (PORTER, $1990 \mathrm{e}$ 1999) sistemas industriais localizados (COURLET, 1993), distritos industriais (BRUSCO, 1982, BAGNASCO, 2000, SCHMITZ, 1995) aglomerados (DINIZ, 2000), e agrupamentos (CNI, 1998, apud TIRONI, 2001). Neste trabalho adota-se a definição Arranjo Produtivo Local (APL), conforme definição do BNDES.

"APL é uma concentração geográfica de empresas e instituições que se relacionam em um setor particular. Inclui, em geral, fornecedores especializados, universidades, associações de classe, instituições governamentais e outras organizações que provêem educação, informação, conhecimento e/ou apoio técnico e entretenimento" (BNDES, 2003).

As concentrações geográficas de empresas podem apresentar diferentes fases de maturidade, de acordo com o grau de interação entre os diversos agentes. Assim, observa-se desde o Arranjo Produtivo Local, que ocorre quando existe concentração de atividades produtivas com características comuns (a interação entre agentes ainda é incipiente) até os Sistemas Produtivos Locais, em que existe alto grau de interação entre os agentes.

Genericamente, são observados dois tipos de vantagens na concentração geográfica de empresas: vantagens externas e as vantagens internas. As vantagens externas foram observadas por autores como VON THÜNEN, WEBER, LÖSCH e CHRISTALLER (apud MiLone, 1998), na chamada teoria clássica da localização, e por Marshall (1982), que chamou essas vantagens de externalidades. Tais vantagens se originam nas condições físicas favoráveis, como proximidade à matéria-prima e infraestrutura de transportes. A proximidade ao mercado consumidor, a especificidade do produto, a presença de mão-de-obra e empresários qualificados, presença de 
fornecedores de equipamentos e outros insumos especializados também são vantagens externas.

Com o surgimento dos distritos industriais italianos, observam-se vantagens externas originadas na organização social e na coordenação da cadeia produtiva assim como vantagens internas às empresas, obtidas pelo equilíbrio entre competição e cooperação.

BAGNASCO (2000) destaca a importância das características sociais e institucionais no processo de industrialização da chamada Terceira Itália, principalmente a capacidade de auto-organização da sociedade italiana, no conceito de capital social. A existência de um agente que coordena a cadeia produtiva também é fundamental para o sucesso dos distritos industriais italianos.

A competição intensa por parcelas do mercado gera estratégias competitivas que buscam maior valor agregado ou minimização de custos.

PORTER (1999) destaca que a intensa rivalidade entre as empresas de uma comunidade assegura pressão continuada para melhorar as tecnologias de processo, minimizando custos e inovando os produtos. $\mathrm{O}$ autor afirma que a localização afeta a vantagem competitiva por meio da influência sobre a produtividade, em especial, sobre o crescimento da produtividade. No que tange à redução de custos, a rivalidade local deve se deslocar dos salários baixos para os custos totais baixos. Quanto à inovação no produto, deve haver evolução da simples imitação de produtos e serviços de baixa qualidade para a inovação e diferenciação. A competição entre empresas concentradas geograficamente acarreta em incentivos à mensuração do desempenho pela facilidade de comparação, porque o orgulho e prestígio na comunidade local instigam as empresas nas tentativas de se superarem.

A cooperação - interação entre agentes - pode ser de caráter horizontal (entre empresas do mesmo segmento) em fases pré-competitivas ou vertical, entre fornecedores e clientes. Podendo ser observadas a forma bilateral (entre duas empresas) e multilateral (entre várias empresas). Como exemplos de cooperação destacam-se as trocas de informações, empregados ou equipamentos entre empresas, os consórcios para compras de insumos ou garantia de crédito (cooperação 
horizontal), o desenvolvimento conjunto de projetos e os programas de qualidade assegurada (cooperação vertical).

A importância da tecnologia na competitividade dos APL's é apontada por diversos autores, se destacando dois aspectos: a) a existência de oferta de infra-estrutura de $\mathrm{P} \& \mathrm{D}$, originando concentrações de empresas em setores não tradicionais e b) os spill overs tecnológicos, a difusão da inovação e do conhecimento tácito. $\mathrm{O}$ papel das inovações, trajetórias e ciclos de vida tecnológicos na competitividade dos APL's ainda não foi analisado e modelado.

As inovações radicais e revolucionárias podem ser fontes importantes de vantagens competitivas para as empresas concentradas geograficamente. No APL italiano de Sassuollo, produtor de cerâmica de revestimento, por exemplo, a mudança no paradigma produtivo de queima dupla para queima simples surgiu pela necessidade dos produtores italianos em reduzir os custos com energia e mão-de-obra, provocando redução no ciclo de produção de 20 horas para 50 minutos. A redução no custo do produto permitiu que as empresas italianas atingissem outras faixas de consumo de cerâmica e ainda se firmassem como exportadoras de equipamentos de produção (PORTER, 1990, ENRIGHT \& TRENTI, apud PORTER, 1999).

\subsection{Perguntas de partida}

A partir das premissas levantadas inicialmente, propõe-se a seguinte pergunta de partida: Por que, onde e como as empresas se concentram geograficamente?

Essa pergunta pode ser dividida nas seguintes questões:

1. Qual é a origem da concentração geográfica de empresas? (Por quê)

2. Onde ocorrem as concentrações geográficas de empresas?

3. Quais são as vantagens competitivas obtidas da concentração de empresas? (Como?)

Essas questões devem ser respondidas genericamente, por modelo conceitual, particularmente, para o APL de Santa Gertrudes. 


\subsection{O segmento de cerâmica de revestimento}

A cerâmica de revestimento é material de construção civil usado para cobrir e dar acabamento a superfícies lisas. Nessa classificação estão os pisos, azulejos, ladrilhos e pastilhas. Esta atividade econômica ligada a este tipo de produção é classificada pelo IBGE, sob o número 10.43.00-5, como transformação de produtos de minerais não-metálicos (IBGE, 1985). De acordo com GORINI \& CORRÊA (1999), a cerâmica de revestimento é um segmento da indústria de transformação, inserida no complexo industrial de materiais de construção.

A produção mundial de cerâmica para revestimentos atingiu 5.773,4 milhões de $\mathrm{m}^{2}$ em 2001, com crescimento médio de 10,5\% ao ano no período 90/2001 (ASCER 2003). O comércio mundial (importações/exportações), naquele ano, foi de 1.215 milhões de $\mathrm{m}^{2}$, com taxa anual de crescimento geométrico no período 98/2001 de $6,4 \%$, correspondendo a $25 \%$ do consumo mundial (World Ceramic Review, apud SEZZI, 2002).

A China é líder em produção e consumo. No ano de 2001 a produção no país foi de 1 bilhão e 600 milhões de $\mathrm{m}^{2}$ Apesar do extraordinário crescimento das exportações chinesas, ainda é pequeno o volume de exportações frente à produção (3\%), caracterizando um mercado praticamente fechado (World Ceramic Review, apud SEZZI, 2002). Apesar dos produtos chineses serem considerados de baixa qualidade, o grés porcelanato chinês pode se destacar no mercado mundial (GORINI \& CORRÊA, 1999).

A Itália tem segunda posição na produção, liderando as exportações. A exportação italiana, apesar de pequeno crescimento, é bastante significativa para a produção do país $(69 \%)$.

A Espanha cresceu muito na década de 90 , se igualando à produção italiana no ano de 2001, com participação de $12 \%$ na produção mundial, sendo também líder em consumo per capita. A Espanha é o terceiro país em exportação, com significativa parcela de sua produção (53\%).

O Brasil é quarto produtor mundial e segundo mercado consumidor de placas cerâmicas. Até o ano de 2000 era o quarto maior exportador, sendo superado pela China em 2001. 
O processo de produção de cerâmica de revestimento apresenta seis fases com padrões tecnológicos distintos: a) mineração, b) mistura e moagem, c) conformação, d) esmaltação, e) queima e f) embalagem. Há que se considerar também a fase de assentamento, fundamental para a qualidade do produto pós-uso.

A cadeia produtiva de revestimentos cerâmicos tem como elos principais as atividades de mineração, produção da massa, fabricação da cerâmica e construção civil. O fornecimento de insumos sintéticos (fritas ${ }^{1}$ e esmaltes, pigmentos e corantes) são elos secundários. Os serviços de apoio não são atividades de transformação, portanto, não são passíveis de inclusão em um esquema teórico de cadeia produtiva, mas são importantes na compreensão da organização do sistema de produção da cerâmica de revestimento (Figura 1).

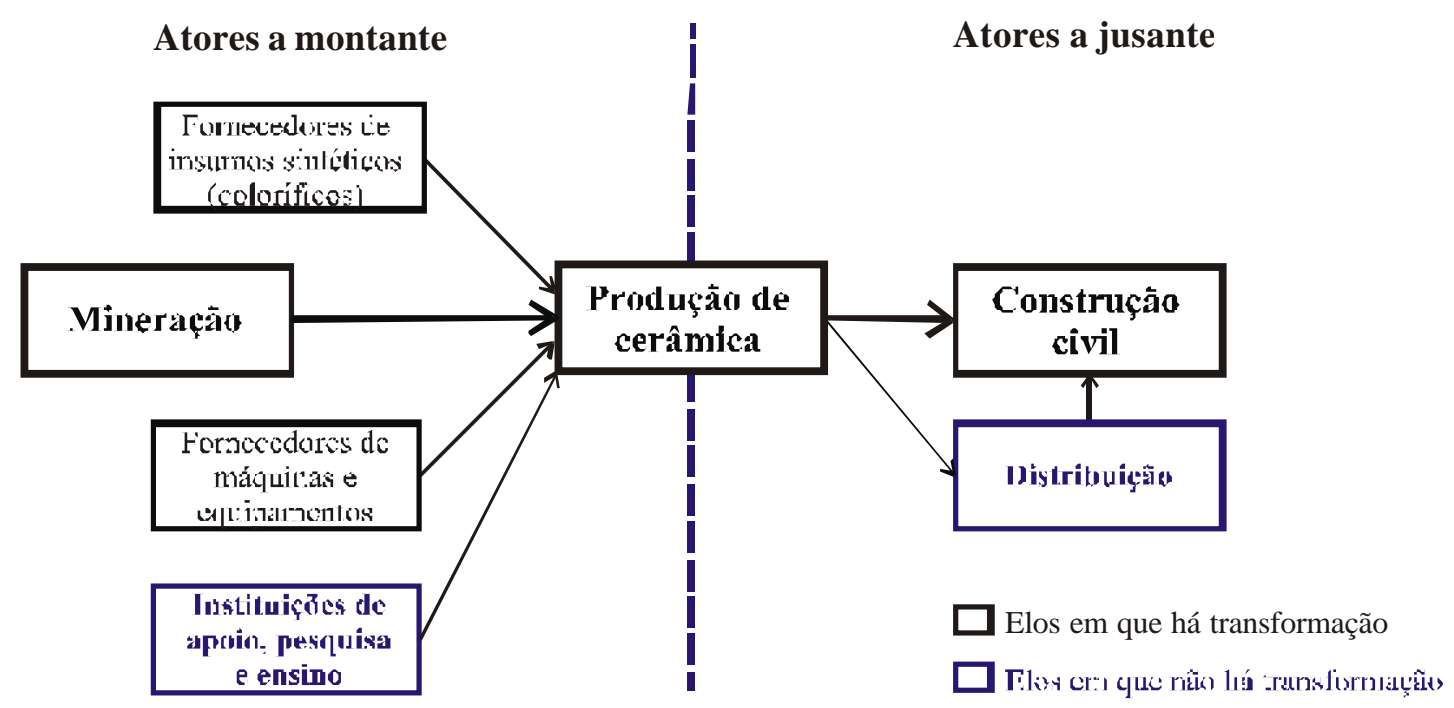

Figura 1 - Cadeia produtiva de revestimentos cerâmicos.

\footnotetext{
1 As fritas são composições de matérias primas fundidas e resfriadas rapidamente, sendo que no processo, as fases minerais cristalinas se transformam em fase vítrea. As fritas são a base do esmalte, que é composto de uma suspensão dessas matérias primas e de eventuais pigmentos.
} 


\subsection{Concentração geográfica no segmento produtor de cerâmica de revestimento}

A concentração geográfica de empresas é característica da indústria produtora de placas cerâmicas de revestimento. Dois dos países líderes, Itália e Espanha, têm produção concentrada nas regiões de Sassuollo e Castellón, respectivamente. A estratégia competitiva dessas regiões baseia-se em design, qualidade e marca. No Brasil, a região de Criciúma, em Santa Catarina, concentra empresas com liderança nacional em qualidade, design e exportação. No estado de São Paulo, atualmente existem dois APL's produtores: o de Mogi Guaçu e o de Santa Gertrudes.

As vantagens competitivas que deram origem a esses APL's estão na combinação de três fatores: oferta de matéria-prima, proximidade com mercados consumidores e capacitação local de trabalhadores e empresários em setores correlatos, como a cerâmica vermelha e estrutural.

Por essas vantagens iniciais os APL's atraíram fornecedores, instituições de P\&D e de apoio. Atualmente, cada um explora diferentes vantagens competitivas, atuando em diferentes nichos de mercado: Sassuollo compete por marca e design, em faixa de mercado de EU 8/ $\mathrm{m}^{2}$; Castellón compete por design e inovação, em faixa de mercado de EU 5/m² (Meyer-Stamer et all., 2000). Ambos tem grande parte da produção destinada à exportação. O APL de Criciúma compete em faixa de R $\$ 8$ a 12/m², com liderança nacional em qualidade e exporta cerca de $25 \%$ de sua produção.

O APL de Mogi Guaçu compete em faixa de mercado entre Criciúma e Santa Gertrudes. O APL de Santa Gertrudes compete em faixa média de mercado de $\mathrm{R} \$ 5 / \mathrm{m}^{2}$, tendo sua vantagem competitiva baseada no custo.

O elo mais forte da cadeia, aquele que detém a governança, e o grau de interação entre os agentes, também apresentam diferenças em cada um dos APL's. Em Sassuollo, o elo mais forte da cadeia é o fornecedor de equipamentos; em Castellón, o fornecedor de tintas e esmaltes. Esses fornecedores têm competitividade internacional. No APL de Criciúma, a governança pertence às grandes empresas, ao 
passo que no APL de Santa Gertrudes, a governança está localizada nos grandes canais de distribuição.

Por fim, observa-se que a dinâmica tecnológica tem grande importância na organização industrial e na concentração ou dispersão geográfica das empresas no setor de cerâmica de revestimento, uma vez que este é setor extremamente dinâmico em inovações e lançamentos de novos produtos.

\subsection{O APL de Santa Gertrudes}

A região formada pelos municípios de Santa Gertrudes, Cordeirópolis, Rio Claro, Limeira, Araras, Piracicaba e Ipeúna concentra 43 empresas produtoras de placas cerâmicas de revestimento (1), além de aproximadamente 20 fornecedores de insumos e matérias-primas específicas para o setor. A cidade de Santa Gertrudes é onde está localizada a maioria das empresas.

Dos 473,4 milhões de $\mathrm{m}^{2}$ produzidos no Brasil em 2001, o APL de Santa Gertrudes produziu aproximadamente 180 milhões de $\mathrm{m}^{2}$, o que corresponde a $38 \%$ do volume de produção nacional (MCT, 2003). O APL de Criciúma, no mesmo ano, produziu 75,3 milhões de $\mathrm{m}^{2}, 15,9 \%$ do total brasileiro (SINDICERAM, 2003).

A maior parte das empresas do APL de Santa Gertrudes tem estratégia competitiva baseada em custo, fabricando produto com preço médio de $\mathrm{R} \$ 5 / \mathrm{m}^{2}$. Essa estratégia permitiu que a região obtivesse crescimento de produção maior que a média nacional, baseado na demanda por produtos de baixo valor após estabilização da moeda alcançada no Plano Real, em 1994, quando uma parcela maior da população passou a ter acesso ao mercado consumidor.

A base da competição por custo no APL de Santa Gertrudes está na produção da massa, na fase de mistura e moagem, por tecnologia via seca. Nessa fase é feita a redução granulométrica dos minerais por meio de moinhos e martelos para a composição da massa. Podem ser adotadas duas tecnologias diferentes para essa fase: via seca e via úmida. No processo via seca, a moagem das matérias-primas é feita por moinhos de martelo e pendulares, sendo levemente umidificada para a prensagem $\left({ }^{2}\right.$.

\footnotetext{
${ }^{1}$ No Brasil atualmente existem cerca de 130 plantas produtivas.

${ }^{2}$ Os pisos feitos por esse processo são típicos de Santa Gertrudes, mas são encontrados também em outras localidades do estado de São Paulo. Outras características peculiares dessas placas são: a cor
} 
Esse processo é mais barato que o processo via úmida, em que a preparação da massa é feita em moinhos de bola, com a secagem e granulação em atomizador. Por outro lado, é mais difícil conseguir massa homogênea na via seca, resultando em produtos de menor qualidade.

Nos demais APL's produtores no Brasil e no mundo a tecnologia via úmida é predominante.

A competição por custo e o ganho progressivo de parcelas consideráveis de mercado permitiram que as empresas modernizassem suas plantas, adquirindo equipamentos com grande capacidade produtiva, aumentando consideravelmente a escala de produção.

Porém, o mercado onde o pólo atua mostra sinais de esgotamento. É necessário, portanto, rever a estratégia de atuação das empresas, que devem buscar mercados de maior valor agregado. Há também a possibilidade de produção de grés-porcelanato pelas empresas locais. Isso implicaria em mudança para uma estratégia baseada em qualidade e design, incorrendo-se nos riscos inerentes à adoção de novo sistema de produção e da competição com produtos catarinenses, italianos e espanhóis. Por outro lado, permanecer com estratégia baseada em custos pode levar rapidamente à corrosão nas margens de lucros, que são muito pequenas para empresas de menor porte.

\subsection{Desenvolvimento do trabalho}

Este trabalho será desenvolvido em 8 capítulos, além de este introdutório. No capítulo 2 é feita descrição das economias internas e externas, de acordo com os principais modelos teóricos encontrados na literatura. O capítulo 3 apresenta $\mathrm{o}$ modelo proposto para compreensão da evolução dos APL's. O capítulo 4 explicita a metodologia proposta para a validação do modelo. No capítulo 5 descreve-se o segmento de cerâmica de revestimento. No capítulo 6 apresenta-se o APL de Santa Gertrudes. No capítulo 7 é feita a validação do modelo. No capítulo 8 são apresentadas as conclusões e recomendações e no capítulo 9 são apresentadas as referências bibliográficas.

da massa ou do suporte é vermelha; não é possível realizar mistura de várias matérias-primas, sendo que a massa é composta só de argila. 


\section{DETERMINANTES DA CONCENTRAÇÃO GEOGRÁFICA DE EMPRESAS}

MARSHALl (1982) observa que o fenômeno da concentração geográfica de atividades econômicas é tão antigo quanto o comércio. Inicialmente, segundo o autor, as necessidades humanas eram supridas por recursos locais. $\grave{A}$ medida que as necessidades se diversificaram e os sistemas de transportes se tornaram mais eficazes, os produtores puderam suprir as necessidades dos consumidores. Artigos como vestuário, especiarias e adornos pessoais passaram a ser produzidos em poucos lugares e difundidos por toda a Europa, nas feiras, ou mesmo nas próprias casas dos compradores. O autor utiliza o nome "indústria localizada" dizendo que é a forma mais comum, embora não mais adequada, de chamar a indústria concentrada em certas localidades.

KRUGMAN (1991a, apud IGLIORI, 2001), afirma que esse fenômeno é resultado da interação entre demanda, retornos crescentes de escala e custos de transportes. Esses retornos ocorrem nas indústrias modernas; nas tradicionais os retornos de escala são constantes ou decrescentes.

As vantagens e economias que motivam determinada empresa a se localizar próxima geograficamente a outras empresas podem ser genericamente classificadas em dois grupos: as economias externas e economias internas.

É importante distinguir economias externas e economias internas porque elas ocorrem com diferente intensidade nos diversos setores, segmentos e APL's e mesmo nas diversas fases de evolução dos APL's e empresas.

SCHMITZ (1995 p. 533) afirma que "o agrupamento de empresas abre oportunidades para ganhos de eficiência que os produtores individuais raramente podem obter". O autor defende a diferenciação entre os ganhos planejados, aqueles que são buscados intencionalmente pelas empresas (economias internas) e os não planejados, ou incidentais (economias externas). A soma desses ganhos ele define como eficiência coletiva. A simples concentração geográfica e setorial das empresas não é garantia de eficiência coletiva, mas é condição necessária para uma série de desenvolvimentos posteriores, que podem ou não ocorrer, como divisão de trabalho e especialização entre produtores; fornecimento de produtos especializados com rapidez; emergência 
de fornecedores de matérias-primas, componentes e máquinas; emergência de agentes que vendem para mercados distantes; o aparecimento de fornecedores de serviços tecnológicos, contábeis e financeiros; a emergência de um grupo de trabalhadores especializados; formação de consórcios e associações para ações específicas. Quanto mais esses elementos estão presentes, mais forte é a eficiência coletiva do APL. As economias externas e internas estão representadas na Figura 2.

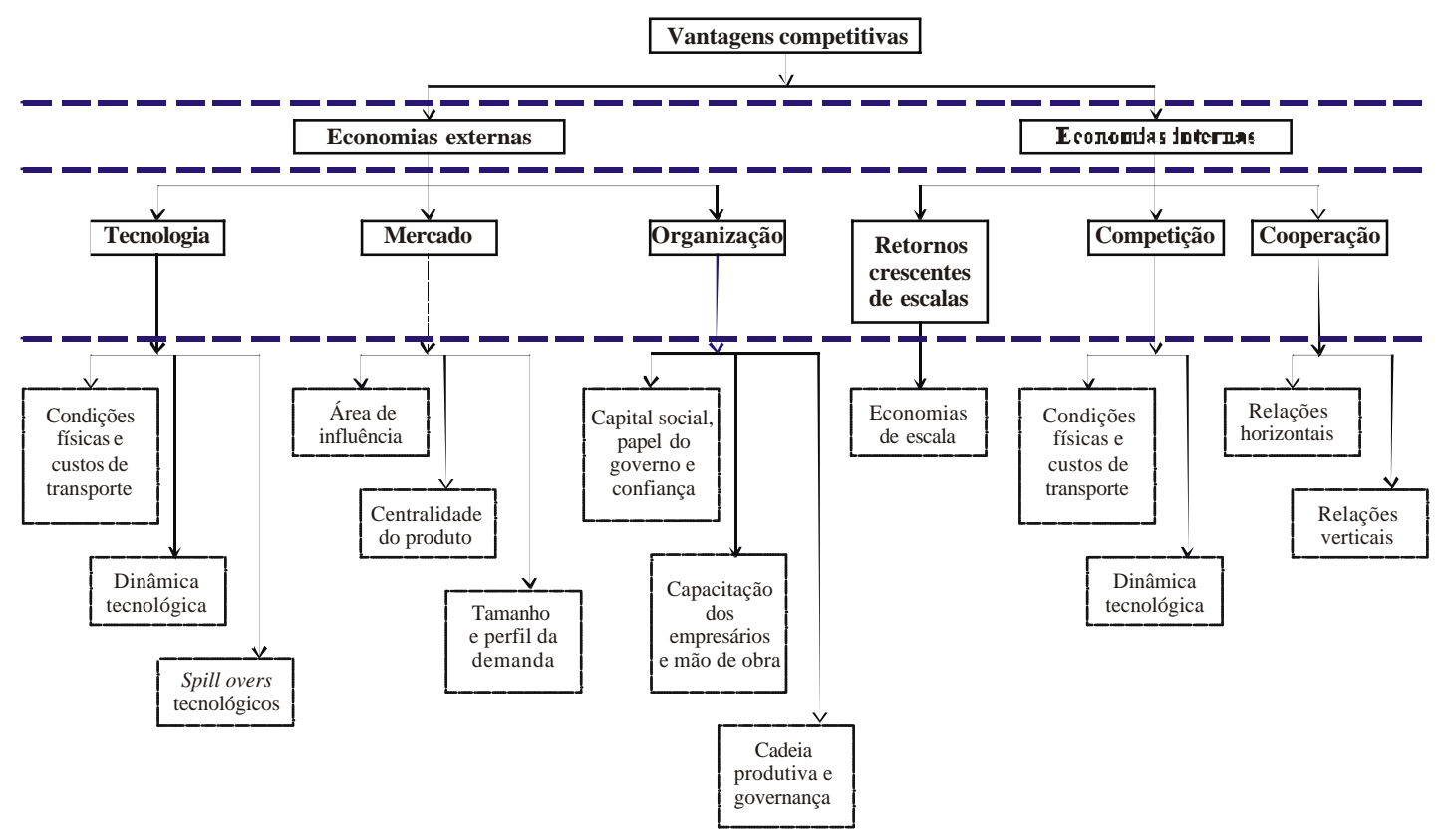

Figura 2 - Determinantes da concentração geográfica de empresas.

\subsection{Economias externas}

As economias externas são serviços ou ganhos que um produtor proporciona a outro sem qualquer compensação SCITOVSKY (1954, apud IGLIORI, 2001), ou seja, são economias incidentais (SCHMITZ, 1994). A concentração geográfica de empresas origina uma série de economias externas que foram observadas por MARSHALL em um modelo posteriormente adaptado por vários autores como PORTER, KRUGMAN e SCHMITZ.

As economias externas podem ser classificadas em três grandes grupos: economias tecnológicas, economias de mercado e economias de organização. 


\subsubsection{Economias externas tecnológicas}

São aquelas que têm impactos na função de produção e dizem respeito aos padrões tecnológicos adotados: condições físicas, oferta de matérias-primas, infra-estrutura de transportes etc.

A teoria clássica da localização enfatiza a importância dos custos de transportes, da oferta de matérias-primas e insumos básicos e a relação entre custos de matériaprima e mão-de-obra como determinantes da decisão de se localizar próximo a outras empresas.

As matérias-primas e insumos básicos utilizados, por sua vez, são determinados pelas trajetórias tecnológicas adotadas. Por exemplo, a tecnologia de produção via seca, no caso do APL de Santa Gertrudes, foi fundamental para viabilizar a utilização da matéria-prima local a preços competitivos.

\subsubsection{Condições físicas e custos de transportes}

De acordo com MARSHALl (1982 p. 232), as condições físicas são "a natureza do clima e do solo, a existência de minas e de pedreiras nas proximidades, ou um fácil acesso por terra ou mar." Os recursos naturais determinam o tipo de indústria que se concentra em específica região, como no caso das indústrias metalúrgicas, localizadas geralmente perto de minas ou lugares com combustível barato A indústria de ferro situa-se nas vizinhanças das minas, a indústria cerâmica, localiza-se onde há argila abundante para fazer os potes de porcelana para queimar as peças.

LÖSCH (apud CLEMENTE \& HIGACHI, 2000) afirma que a concentração geográfica de empresas se origina na oposição de duas forças: economias de escala e custos de transportes. A dispersão total das empresas não ocorre porque existem economias de escala que reduzem o custo unitário das produções concentradas e a concentração total não ocorre porque existem custos de transportes. As economias de escala agem no sentido de concentrar as empresas: quanto maior for a economia de escala, maiores são as reduções de custo, estimulando a concentração geográfica das atividades produtivas. Isso significa que as reduções nos custos de transportes e o aumento das economias de escala levam a um aumento nesse tipo de concentração. 
ISARD (1956, apud ClEMENTE \& HigACHI, 2000) adiciona o custo de transporte à função de produção clássica, considerando-o como insumo da produção. $O$ custo de transporte depende do valor das tarifas, que por sua vez, depende da estrutura concorrencial do setor e da quantidade a ser transportada. RICHARDSON (1975, apud ClemENTE \& HigACHI, 2000) faz analogia entre o conceito de insumo transporte e o de taxa de juros, sendo que o insumo de transporte representa desconto em relação ao espaço, como o juro representa desconto em relação ao tempo.

VON THÜNEN (apud ClEMENTE \& HIGACHI, 2000), no início do século XIX, analisou a localização das atividades agrícolas e o seu padrão de distanciamento ao centro do mercado consumidor, considerando o objetivo da maximização da renda da terra. Nesse modelo, que pode ser utilizado para análise das atividades industriais, a receita é função da distância entre o mercado consumidor e o centro produtor, de acordo com a expressão (1).

$$
R=(P-C)-T X D
$$

Em que:

$\mathrm{R}=$ rendimento por unidade de produto comercializado;

$\mathrm{P}=$ preço de um produto no centro do mercado;

$\mathrm{C}=$ Custo de produção fob (posto fábrica);

$\mathrm{T}=$ custo de transporte por unidade de produto e

$\mathrm{D}=$ distância do centro produtor ao centro do mercado

Assumindo que $\mathrm{P}, \mathrm{C}$ e $\mathrm{T}$ são constantes para cada produto, observa-se que o rendimento é função apenas de $\mathrm{D}$, de acordo com a expressão (2).

$$
R-f(D)
$$

As culturas que ocupam as áreas mais próximas ao centro consumidor apresentam maior lucro bruto de produção, por unidade de terra utilizada.

A base do modelo proposto por WEBER (apud CLEMENTE \& HigACHI, 2000) é a minimização do custo. $\mathrm{O}$ autor estabelece o conceito de fator locacional como sendo a economia de custo que a indústria pode obter ao escolher sua localização. É 
necessário distinguir os fatores locacionais gerais, que dizem respeito a todas as indústrias, dos fatores locacionais específicos, relativos a uma indústria em particular. WEBER se detém nos fatores gerais, classificados em fatores regionais e fatores aglomerativos, de acordo com a escala geográfica em que atuam. Os fatores regionais são aqueles capazes de explicar a escolha entre regiões, enquanto os fatores aglomerativos e desaglomerativos explicam a concentração ou dispersão da indústria em determinada região.

WEBER apresenta modelo de análise comparativa entre os custos de transportes e os custos de mão-de-obra. Esse custo é a soma dos custos de transporte da matériaprima com o transporte do produto acabado. Para o autor existem dois tipos de matérias-primas: as ubiqüidades, que podem ser encontradas em qualquer lugar - não tem custos de transportes, e as matérias-primas localizadas, encontradas apenas em lugares específicos.

O custo de transporte é analisado a partir de dois indicadores: Índice Material e Peso Locacional. O Índice Material é obtido pelo coeficiente entre peso das matériasprimas localizadas e o peso do produto final, conforme a equação (3).

$$
I M=\frac{P_{m p}}{P_{p f}}
$$

Em que:

$\mathrm{IM}=$ Índice Material

$\mathrm{P}_{\mathrm{mp}}=$ Peso da matéria-prima localizada

$\mathrm{P}_{\mathrm{pf}}=$ Peso do produto final

O Índice Material pode variar entre o valor mínimo de zero, quando só são transportadas ubiqüidades, até valores maiores que 1, quando o peso do produto final é menor que o das matérias-primas localizadas. Isto significa que há perda de peso no processo de transformação.

O Peso Locacional (PL) é a razão entre o peso total a ser transportado e o peso do produto final. $\mathrm{O}$ peso total a ser transportado é a soma do peso das matérias-primas localizadas mais o peso do produto final, segundo as equações (4) e (5). 


$$
\begin{gathered}
P L=\frac{P_{m p}+P_{p f}}{P_{p f}} \\
P L=I M+1
\end{gathered}
$$

O Peso Locacional mostra a importância relativa do transporte entre matéria-prima e produto final. Quando PL é elevado significa que a matéria-prima tem maior impacto no custo de transporte, sendo que as atividades produtivas devem estar localizadas próximas às suas fontes. Quando PL é pequeno significa que o custo de transporte do produto final tem maior relevância, devendo localizar as unidades produtivas mais próximas ao centro consumidor.

A importância da mão-de-obra em relação ao custo de transporte é analisada por meio do Índice de Custo de Mão-de-Obra e do Coeficiente de Mão-de-Obra. O índice de custo de mão-de-obra é a relação entre o custo de mão-de-obra e o peso do produto acabado, conforme equação (6).

$$
I C=\frac{C_{m o}}{P_{p f}}
$$

Em que:

IC = Custo de mão-de-obra (unidades de salário por peso de produto acabado)

$\mathrm{C}_{\mathrm{mo}}=$ Custo de mão-de-obra

$\mathrm{P}_{\mathrm{pf}}=$ Peso do produto acabado

$$
C M=\frac{I C}{P L}
$$

O Coeficiente de Mão-de-Obra (CM) é definido como a razão entre o Índice Custo de Mão-de-Obra (IC) pelo Peso Locacional (PL), conforme a equação (7).

Quando o coeficiente de mão-de-obra é alto, significa que o custo da mão-de-obra prevalece sobre o de transporte e vice-versa.

\subsubsection{Dinâmica tecnológica}

As diferentes trajetórias tecnológicas adotadas para a produção de determinado bem ou serviço têm influência direta na relação entre custos fixos e custos variáveis e na 
existência de retornos crescentes de escala. As trajetórias que demandam altos custos fixos comparativamente aos custos de transportes viabilizam a concentração de atividades econômicas em uma única localidade.

A tecnologia apresenta comportamento cíclico que interage com a dinâmica industrial. Quando surge novo conjunto de conhecimentos tecnológicos, que muda os paradigmas estabelecidos (científicos ou de produção) ocorre o que SCHUMPETER (1942, apud CoOMBS et al., 1982) chamou de "destruição criadora", fenômeno que propicia o surgimento de inovações radicais que levam à emergência de setores industriais completamente novos e criam um potencial de renovação para $o$ desenvolvimento econômico, mudando radicalmente a estrutura industrial vigente. A destruição criadora de SCHUMPETER, pode ser associada com a inovação radical, que é aquela que rompe com a lógica de resolução de problemas de produção e engenharia vigentes, ou seja, origina novo paradigma tecnológico, a partir do qual desenvolve-se uma série de melhorias pontuais, as inovações incrementais. $O$ conjunto de inovações incrementais em determinado paradigma é chamado de trajetória tecnológica (DOSI, 1982). A escolha de um conceito tecnológico central paradigma - por exemplo, motor a combustão interno na indústria automobilística, estabelece uma agenda - trajetória - para o desenvolvimento técnico de um produto.

A escolha realizada pelo consumidor também ajuda a estabelecer uma agenda para o desenvolvimento tecnológico. Um exemplo é o modelo "T" da Ford, resultado da evolução conjunta de decisões tecnológicas tomadas por projetistas e da demanda por um "meio básico de transporte" durável, confiável e de baixo custo ABERNATHY (1978, apud UTTERBACK \& SUAREZ, 1990).

A emergência de um design dominante é vista como o resultado de interação entre escolhas técnicas e de mercado.

ABERNATHY \& CLARK (1988) consideram fundamental distinguir entre os efeitos da inovação no mercado e no processo de produção, pois dada inovação pode afetar os dois domínios de diferentes formas. As inovações que ocorrem no mercado são chamadas de arquitetônica (radical) e criadoras de nicho (incremental). As inovações no processo produtivo podem ser do tipo revolucionária (radical) e regular (incremental). 
A inovação arquitetônica pressupõe a criação de novas indústrias ou a reformulação de antigas. Inovações desse tipo definem a configuração básica do produto e do processo, estabelecem agendas técnicas e de mercado que irão guiar o desenvolvimento subseqüente. Exemplo de inovação arquitetônica é o grésporcelanato, produto com características superiores que compete com o mercado de rochas ornamentais e tem maior valor agregado.

A inovação criadora de nicho proporciona a abertura de novas oportunidades de negócio pelo uso da tecnologia vigente. Seu efeito nos sistemas técnico e de produção é conservar e melhorar as trajetórias tecnológicas estabelecidas. Nessa fase, terá vantagem competitiva aquele que primeiro lançar a inovação, que está disponível, em novos mercados. Exemplo de inovação de nicho pode-se citar o lançamento de placas cerâmicas de grandes dimensões ou o porcelanato com esmalte.

A inovação regular é, freqüentemente, quase invisível, tendo efeito cumulativo no custo e desempenho do produto. Essa categoria de inovação envolve mudanças incrementais nas competências estabelecidas; é aplicada a mercados e consumidores existentes. O efeito dessas mudanças é a consolidação das habilidades e recursos existentes. Novas formulações de esmalte, mudanças incrementais na prensa e na linha de produção são exemplos de inovações regulares no segmento de cerâmica para revestimento.

A inovação revolucionária é aquela que rompe com a tecnologia vigente e obsoletiza as competências de produção. É aplicada a mercados existentes.

As inovações arquitetônicas, criadoras de nicho e revolucionárias podem gerar economias externas, a partir da criação de novos mercados, expansão de mercados existentes ou nova trajetória tecnológica que muda as relações entre custos fixos e custos variáveis, possibilitando retornos crescentes de escala e originando novos padrões competitivos em determinada localidade, como aconteceu com a adoção da tecnologia via seca pelas empresas produtoras de cerâmica de revestimento na região de Santa Gertrudes. 


\subsubsection{Spillovers tecnológicos}

KRUGMAN interpreta MARSHALL destacando o papel dos chamados spill overs tecnológicos, que seriam transbordamentos de conhecimento e de tecnologia. A proximidade geográfica facilitaria o processo de circulação das informações e dos conhecimentos, por meio da construção de canais próprios de comunicação e de fontes de informação especializadas. O exemplo mais famoso seria o do Vale do Silício e o de Boston (Rota 128), que são arranjos produtores de alta tecnologia (GARCIA, 2002; IGLIORI, 2001)

PORTER (1999 p. 229) destaca a importância do acesso à informação, dizendo que nos aglomerados ele é de melhor qualidade e com menor custo, facilitando o aumento de produtividade das empresas. De acordo com o autor:

"Os elos decorrentes da proximidade, das relações de fornecimento de tecnologia, além daqueles forjados pelos relacionamentos pessoais e pelos laços comunitários fomentadores da confiança, facilitam o fluxo das informações."

\subsubsection{Economias externas de mercado}

As economias externas de mercado são fruto de decisões ou fenômenos externos às empresas e são mediadas por mecanismos de mercado. A elasticidade da demanda ao preço, por exemplo, combinada com as economias de escala das trajetórias tecnológicas adotadas, determina os retornos crescentes de escala e tem impactos na função lucro das empresas individuais. Essa elasticidade é determinada pelo tamanho e perfil do mercado consumidor, assim como pela centralidade do produto. Os bens e serviços centrais são aqueles que não podem ser encontrados em qualquer parte, têm maior valor agregado.

\subsubsection{Variações espaciais da demanda e centralidade do produto}

De acordo com LÖSCH (CLEMENTE \& HIGACHI, 2000) a demanda por um produto é decrescente à medida que aumenta a distância ao centro produtor, uma vez que há aumento no custo de transporte, e conseqüentemente, no produto final. Admitindo 
que a variação da demanda seja linear, a função da demanda assume a seguinte forma [equação (8)]:

$$
Q=a-b . P
$$

Em que Q é a demanda pelo produto e $\mathrm{P}$ é o preço final do produto. Uma vez que $\mathrm{P}$ varia com a distância em função do custo de transporte, tem-se que [equação (9)]:

$$
P=P_{0}+t \times x
$$

Em que:

$\mathrm{P}_{0}=$ preço FOB (posto fábrica)

$\mathrm{t}=$ tarifa de transporte por unidade de distância

$\mathrm{X}=$ distância

Pode-se reescrever a função da demanda em relação à distância:

$$
Q=\left(a-b \times P_{0}\right)-b \times t \times x
$$

Uma vez que $P_{0}$ e t são fixos, a demanda deve variar apenas com a distância ao centro consumidor. $\mathrm{O}$ valor máximo da demanda ocorre quando $\mathrm{x}=0$ e $\mathrm{o}$ valor mínimo, $\mathrm{Q}=0$, ocorre na distância máxima a ser atingida por aquele produto, que pode ser considerada o raio de sua área de influência.

$$
X_{\max }=\frac{a-b \times P_{0}}{b \times t}
$$

Christaller (1996, apud Clemente \& HigaChI, 2000) propõe modelo de hierarquização dos lugares a partir de indicador chamado centralidade. A centralização é tendência natural da produção. Os núcleos urbanos são fornecedores de bens e serviços, tanto para si mesmos como para lugares de menor centralidade. Os bens e serviços centrais são aqueles que não são encontrados em qualquer parte. A centralização de ofertas e bens não pode ser explicada apenas por razões geográficas, uma vez que o centro geográfico nem sempre é lugar central. O conceito de distância geográfica é substituído pelo de distância econômica. Cada produto apresenta certa área de domínio espacial de mercado. Produtos de elevada centralidade são disponíveis apenas em alguns lugares e são buscados a longas 
distâncias econômicas, enquanto produtos de menor centralidade são encontrados em vários lugares e são buscados a distâncias menores. Existe, então, relação direta entre a centralidade do produto e o tamanho de sua área de influência; quanto maior a centralidade, maior a área de influência.

A centralidade de um produto é determinada por dois fatores básicos. A demanda é definida pela importância relativa dos custos de acesso e a oferta é determinada pelas economias de escala.

\subsubsection{Condições de demanda}

As condições de demanda de um produto ou serviço fazem parte do segundo conjunto de determinantes da vantagem competitiva, no modelo do diamante proposto por PORTER (1990). É devido à pressão dos compradores internos que as empresas passam a inovar e assim tornam-se mais competitivas em relação às congêneres de outros países.

As condições de demanda podem ser indutoras de inovação quando os consumidores exigem qualidade e variedade em produtos ou serviços, pressionando as empresas a inovar e variar seu portfólio de produtos. A indústria japonesa, por exemplo, começou a trabalhar com a melhoria da eficiência energética antes do resto do mundo, que só se preocupou com a questão depois do primeiro choque do petróleo. Esse comportamento foi motivado pelos consumidores japoneses, que podem ser considerados adotantes avançados, uma vez que estavam preocupados com os custos da energia. Essa preocupação foi ampliada pela divulgação de inúmeros relatórios, publicidade e algumas medidas governamentais que viabilizaram a adoção adiantada de produtos. Enquanto isso, nos EUA, os custos de energia foram mantidos artificialmente baixos.

Além das necessidades indutoras de inovação, o tamanho e os padrões de crescimento da demanda são fatores relevantes para sua caracterização. Em empresas em que há economias de escala, ter mercado interno de grandes proporções pode significar vantagem competitiva.

O crescimento do mercado interno na indústria de aparelhos domésticos na Itália é exemplo muito interessante. Essa indústria cresceu rapidamente: em menos de uma 
década tornou o país líder em exportação para o mercado europeu. Uma das razões desse crescimento foi o surto interno na demanda na década de 50.

\subsubsection{Economias externas de organização}

As economias externas de organização (social e da produção) são aquelas determinadas pelas características da população local e que se refletem na forma como os trabalhadores, empresários e empresas se estruturam localmente. O pimeiro autor a identificar a importância do perfil da população local foi MARSHALL.

De acordo com o autor, "o desenvolvimento industrial das nações segue as oportunidades de caráter". As capacitações têm origem em "tempos recuados" e:

"as vantagens naturais podem ter estimulado por si mesmas a liberdade de indústria e de empresa, mas é a existência destas últimas, qualquer que tenha sido o motivo que as fez nascer, que constitui a condição suprema de desenvolvimento das nobres formas das artes da vida." (MARSHALL, 1982 p. 233).

Outra característica social destacada por MARSHALL é o papel da elite, ou o patrocínio das cortes. Segundo o autor:

"O rico contingente lá reunido dá lugar a uma procura para as mercadorias de uma qualidade excepcionalmente alta, e isso atrai operários especializados, vindos de longe, ao mesmo tempo que educa os trabalhadores locais." (MARSHALL, 1982).

Marshall observou duas formas de economias de organização da produção: a formação de um contingente de mão-de-obra especializada, a criação de indústrias produtoras de insumos e máquinas especializadas.

Mais recentemente, BAGNASCO (2000), sociólogo italiano, enfatizou o papel das características sociais ao descrever o processo de industrialização da chamada Terceira Itália. Com pouco capital e contingente de trabalhadores rurais disponíveis, empresas adaptaram o conhecimento artesanal tradicional às novas tecnologias e equipamentos modernos, para fornecer produtos em setores tradicionais em que a produção de massa estava ausente ou em novos setores da especialização flexível, como vestuário, móveis e materiais de construção. 
O autor destaca a capacidade de auto organização da sociedade italiana, na experiência de desenvolvimento observada na região da Emília Romana. O surgimento de grupos de pequenas empresas justifica-se com o esgotamento dos sistemas de produção em massa. A busca de novos nichos de mercado exige especialização e flexibilidade, o que demanda das empresas capacidade de construir redes de relações extensas e variadas. O papel dos trabalhadores é diferente, sendo necessária a capacidade de auto supervisão, dado que há menos controle da hierarquia. A disseminação da terceirização também contribuiu para o aparecimento de pequenas empresas fornecedoras, que devem ter maior autonomia com relação às grandes empresas.

A família desempenha papel importante no desenvolvimento dos distritos industriais italianos. A empresa é preocupação da família, geralmente, os parentes trabalham juntos para a estratégia comum.

BAGNASCO destaca ainda que o desenvolvimento dos distritos industriais na Terceira Itália aconteceu de forma autônoma com relação às políticas públicas, isso não significa que o mercado, por si só, é suficiente para alavancar o processo. O sucesso dos distritos industriais italianos se deve à combinação de oportunidades de mercado e recursos específicos da sociedade local. Esses recursos podem ser agrupados no conceito de capital social.

O papel do governo também foi observado por PORTER (1999). Uma das principais funções do governo é assegurar a estabilidade macro-econômica e a produtividade dos insumos básicos.

\subsubsection{Capital social}

\subsection{Definição}

De acordo com definição do Banco Mundial,

"o capital social se refere a instituições, relações e normas que formatam a qualidade e quantidade das interações sociais. $\mathrm{O}$ capital social não é apenas a soma de instituições que compõem uma sociedade, mas sim a cola que a mantém unida" (WORLBANK, 2002). 
PUtNAM (1996, apud NASCIMENTO, 2000) define capital social como um estoque de relações sociais empenhadas (compromissos tácitos ou não) numa comunidade, baseando seu êxito no fortalecimento da cooperação e da confiança mútua. O capital social seria recurso produtivo como o capital físico e o capital humano.

O capital social apresenta ainda, três dimensões básicas: cultural, participativa e comunitária. A dimensão cultural é importante, dado que é por seu meio que a sociedade gera e transmite valores. As tradições e as formas de relacionamento com a natureza e capacidade de auto-organização são os primeiros recursos das populações que não possuem riquezas físicas. A dimensão participativa faz com que as populações passem de beneficiários de políticas públicas a agentes dessas políticas, possibilitando processo de negociação e argumentação social. A participação favorece a inclusão dos cidadãos nos processos decisórios e permite a consolidação da lealdade e confiança dos mesmos. Por fim, o capital social comunitário é constituído das "normas práticas e relações formais e nformais, dentro e fora das instituições" (NASCIMENTO, 2000).

O capital social comunitário de acordo com NASCIMENTO, pode ocorrer nas seguintes formas:

- Reciprocidade vertical, em que existem lideranças fortes com capacidade de negociação e mobilização interna e externa;

- Semi-clientelismo, em que existe agente externo capaz de mobilizar, a partir de programas, a população local;

- Repertórios culturais optativos, normas e costumes que surgem da ruptura de sistemas clientelistas e autoritários.

Visão mais estreita focaliza apenas as relações horizontais entre as pessoas, consistindo das redes sociais e normas associadas que têm efeitos na produtividade da comunidade. As redes sociais podem aumentar a produtividade reduzindo os custos das transações econômicas. O capital social também facilita a cooperação. É necessário observar os impactos, positivos e negativos, das associações verticais entre as pessoas, o que inclui as relações entre organizações e empresas. Essa visão reconhece que as relações horizontais são importantes para dar à comunidade senso de identidade às propostas comuns. Se não houver alianças que transcendam as 
várias divisões sociais (religião, etnia, condição sócioeconômica), as ligações horizontais podem resultar na busca de interesses específicos e de curto prazo; podem dificultar a difusão de informações e recursos por toda a comunidade (WORLBANK, 2002).

\subsection{Fontes de capital social}

Existem várias fontes de capital social, sendo as mais importantes a família, as comunidades, as firmas, a sociedade civil e o poder público.

A família é a primeira fonte de capital social para a sociedade em seu conjunto, uma vez que é a principal fonte de bem estar social para seus membros. Além de influir no desenvolvimento social e humano das crianças, as relações internas e externas da família modelam os comportamentos que são transmitidos para as gerações futuras. As relações na família ajudam o desenvolvimento da confiança, essencial para a formatação das relações externas. As relações informais entre parentes podem também levar à formação de empresas, associações de crédito, fornecem mão-deobra barata e segurança financeira. Por outro lado, as relações familiares muito fortes podem impor barreiras às relações com redes externas.

As interações sociais entre os vários grupos em comunidade, como vizinhos, amigos e membros de associações, são geradoras de capital social e da habilidade de trabalhar para um objetivo comum. A confiança entre os grupos da comunidade pode servir de substituto para o capital humano e físico em comunidades pobres. Além disso, pode levar à redução de problemas sociais como a violência, aumentar as oportunidades de negócios possibilitando acesso informal ao crédito e melhorando a qualidade da educação e saúde. Altos níveis de participação em associações cívicas ajudam a resolver problemas coletivos. A interação freqüente ajuda a cultivar normas de reciprocidade, melhoram a coordenação, comunicação e acesso à informação e a colaboração bem sucedida encoraja esforços de colaboração em outras áreas.

As atividades econômicas são de responsabilidade de organizações e requerem alto grau de cooperação social (FUKUYAMA, 1995, apud WORLBANK, 2002).

A construção e manutenção de empresas que funcionam eficientemente necessitam de confiança e um enso de proposições comuns. O capital social reduz os custos de transação, dado que facilita a cooperação e a coordenação. Os ganhos de eficiência 
em tempo e informações permitem maior alocação de recursos na produção e comercialização de um melhor produto com maior volume. Esse capital afeta as empresas internamente, em suas relações com outras empresas no mesmo segmento, com empresas de outros segmentos e em sua relação com a sociedade.

As organizações não governamentais são afetadas pelo capital social à medida que ele possibilita que as relações informais e a confiança aglutinem pessoas com objetivos comuns para a realização de ações.

A gestão do poder público é facilitada pela confiança e relações informais entre os funcionários eliminando níveis burocráticos. O capital social também promove a transparência das atividades do governo e melhora o fornecimento de serviços públicos.

\subsection{Papel do governo}

O papel dos governos e das políticas estaduais no desenvolvimento econômico foi considerado por PORTER (1999) como sendo tão ou mais importante que o governo federal. $\mathrm{O}$ autor afirma que o governo não tem competência para atuar diretamente nos mercados, uma vez que só as empresas que neles competem é que conhecem de perto as preferências dos clientes e as estratégias dos concorrentes. PORTER identifica cinco categorias básicas para o papel do governo. A primeira é manter a estabilidade macro-econômica, sendo necessário o "desenvolvimento de instituições governamentais sólidas". A segunda categoria de atuação do governo é garantir a produtividade dos insumos e infra-estrutura. A terceira é a definição de regras gerais micro-econômicas que garantam o direito dos consumidores, além de "estatutos sobre a governança corporativa que enfatizem a responsabilidade dos gerentes pelo desempenho; e um processo de regulamentação eficiente, que promova a inovação ao invés do congelamento do status quo".

A quarta atribuição do governo, que PORTER assinala como assumindo importância crescente, é o papel de facilitador do desenvolvimento e aprimoramento dos APL`s, estabelecendo como objetivo "o reforço de todos os aglomerados, sem estabelecer preferências". O autor defende que todas as "empresas são capazes de operar com maior produtividade em qualquer setor - calçados, agricultura e semicondutores - se aplicarem métodos sofisticados. Todos os setores dispõem de condições de empregar 
alta tecnologia". O autor questiona o significado do termo high tech, preferindo o termo tecnologia capacitadora. Outra forma de o governo incentivar a melhoria do cluster é "motivar, facilitar e proporcionar incentivos à ação coletiva pelo setor privado".

Como último papel para o governo (PORTER, 1990 p. 260) destaca a necessidade de "desenvolver um programa de ação de longo prazo, positivo e diferenciado". O autor justifica a necessidade pela existência de forças que se opõem ao desenvolvimento, com visões obsoletas de competitividade.

PUTNAM (1996) busca compreender o sucesso da Terceira Itália por meio de avaliação do desempenho institucional, propondo doze indicadores. $\mathrm{O}$ autor credita $\mathrm{O}$ sucesso da região à iniciativa do governo italiano, na década de 70 , de romper com "a secular tradição italiana de governo centralizado, delegando aos novos governos regionais poderes e recursos sem precedentes".

Foi realizada avaliação dos procedimentos administrativos, em cada governo regional italiano, focalizando em três temas: continuidade administrativa, deliberações sobre a política e implementação das políticas.

O autor enfatiza que está analisando produtos e não resultados: os serviços de saúde, não as taxas de mortalidade, dado que "os resultados sociais são influenciados por muitas coisas além do governo".

$\mathrm{Na}$ categoria continuidade administrativa, o autor sugere três indicadores: estabilidade do gabinete, presteza orçamentária, serviços estatísticos e de informação. Os indicadores que avaliam os procedimentos deliberativos sobre a política, baseados em amplo exame da legislação regional, são a abrangência, coerência e criatividade da egislação reformadora, o grau de inovação legislativa. $\mathrm{Na}$ última categoria, implementação de políticas, são analisados os seguintes índices: número de creches por população, número de clínicas familiares, instrumentos de política industrial (incluindo parques, agências de financiamento, consórcios de desenvolvimento e comercialização e programas de capacitação no emprego). Além desses, há que se analisar a capacidade de efetuar gastos na agricultura, gastos com unidade sanitária local, habitação e desenvolvimento urbano e sensibilidade da burocracia. 


\subsection{Confiança}

O papel da confiança é importante porque as transações econômicas estão sujeitas a risco e oportunismo. Na hipótese de concorrência perfeita, o risco é regulado por informação e racionalidade perfeitas, sem oportunismo. A perfeita informação não existe porque nem sempre está disponível, caso esteja, ela pode ter custo muito grande.

O oportunismo ocorre porque os agentes buscam interesses próprios, mesmo não havendo fraude. Quando as empresas $æ$ sentem inseguras a respeito de um cliente ou fornecedor, as transações terão maior custo, pois são necessárias inspeções e pagamento à vista. Para operar com um mínimo de previsibilidade, as empresas devem estar habilitadas a aceitar e emitir pedidos. Existem limites sobre os quais uma transação econômica pode ser prevista e formalizada. Há duas formas majoritárias de lidar com os riscos: as penalidades e a confiança. Dado que alguns são mais oportunistas que outros, é necessário criar incentivos e penalidades que tornem sem atrativo não cumprir acordo (HUMPRHEY \& SCHMITZ, 1998).

As definições de confiança apresentam dois elementos chave: aceitação do agente que existe risco originado nas ações de outros e a expectativa de que o parceiro não se valerá das oportunidades abertas pela aceitação do risco por parte dos agentes, mesmo quando os parceiros podem ganhar com comportamentos oportunistas, eles vão refreá-los.

Tanto as sanções como a confiança, em suas diferentes formas, aumentam a previsibilidade do comportamento do parceiro nas transações. Quando existe, essa previsibilidade facilita muito a troca. Em alguns casos, a sanção e a confiança podem ser substituídas uma pela outra. A existência de sanções efetivas e baratas leva as empresas a economizar em confiança, e em que quando a confiança existe, as empresas podem reduzir os custos e complicações de organizar sanções. De forma similar, em que os contratos não podem ser viabilizados, as empresas devem construir relações de confiança para sustentar as mais simples transações. A maior parte das relações envolve tanto sanções como confiança.

HUMPRHEY \& SCHMITZ (1998) propõem três níveis de operação das sanções e da confiança. No nível macro ou impessoal as sanções podem ser potencialmente 
aplicadas para todas as transações interfirmas. As sanções no nível meso são aplicáveis a grupos de empresas, geralmente no âmbito setorial. No nível micro são aplicadas para empresas específicas e dependem da relação entre os agentes particulares (Quadro 1).

No nível impessoal de agregação, as sanções são aquelas previstas nos contratos, que estabelecem os termos da troca e as compensações legais. Tais previsões contratuais são a prática de negócios padrão. No nível meso as atividades regulatórias dos setores são importantes, como nos setores bancário e financeiro, a aderência a normas e procedimentos criados para proteger clientes pode ser monitorada por agências reguladoras. Em alguns países, como a Alemanha, os "corpos" setoriais têm importante papel na regulação das relações entre empresas (LANE \& BACHMANN, apud. HUMPRHEY \& SCHMITZ, 1998). As sanções também podem ocorrer informalmente na rede de empresas. Um exemplo é a perda de reputação como conseqüência de comportamento inadequado. Uma empresa pode não somente perder seus parceiros de negócios, como também sofrer rejeição social. Aquele que não cumprir as regras pode sofrer ostracismo social, além de punição econômica. Os sistemas podem estar ajustados para reduzir tanto os custos de transação como o risco do comportamento oportunista (MEAD, 1984, apud HUMPRHEY \& SCHMITZ, 1998).

No nível micro as sanções são aplicadas nas relações de troca específicas. As relações devem beneficiar ambas as partes para ter sustentabilidade a longo prazo. $\mathrm{O}$ uso de garantias para reforçar os acordos é uma segurança adicional para penalizar o comportamento oportunista entre firmas.

As sanções são fundamentais nas relações de negócios, mas têm seus limites. No nível macro, os contratos podem ser caros para elaborar e manter. O uso de contratos para penalizar o não cumprimento pode inibir potenciais parceiros de realizar as trocas, principalmente se os contratos não reconhecem razões legítimas para eventuais falhas. No nível meso, o efeito restritivo da perda da reputação só ocorre quando existe comunidade de troca. A regulação setorial por associações de classe setoriais ou agências de regulação legalmente estabelecidas é ocasional em sua cobertura e eficiência. No nível micro, a decisão da parte prejudicada de romper a 
relação tem como consequiências o sacrifício de seu próprio ganho futuro, assim como o do parceiro.

O uso de sanções é mais efetivo quando a relação de troca é claramente delimitada, o nível de incerteza é baixo e a pressão legal é facilitada. Se a troca está sujeita a contingências imprevisíveis (rupturas climáticas, políticas ou econômicas) fica difícil e caro elaborar contratos prevendo variadas situações possíveis. Em casos de assimetrias de informação de mercado, um dos parceiros pode não estar habilitado a monitorar a transação e avaliar seus termos. Exemplo apresentado por KOLLOCK (1994, apud HUMPRHEY \& SCHMITZ, 1998) é o da confiança desenvolvida na indústria de borracha. A qualidade da borracha no ato da venda é conhecida pelo vendedor, mas não pelo cliente, que fica sujeito a riscos. À medida que as transações interfirmas se tornam cada vez mais complexas, as macro-sanções se tornam menos apropriadas para regular as relações. Muitas relações interfirmas envolvem múltiplas relações que não são suscetíveis de compensação legal.

O foco único nas sanções pode limitar severamente o desenvolvimento das relações de troca. Platteau (1994, apud Humprhey \& SCHMitZ, 1998) coloca a seguinte questão: "como, num mundo caracterizado pela informação imperfeita é possível conter o risco e estabelecer uma troca eficiente?". Depois de analisar os sub-ótimos resultantes de vários jogos baseados na busca do próprio interesse, PLATTEAU concluiu que interesse próprio não é capaz de fornecer suporte a uma troca eficiente.

"Se os indivíduos não confiam uns nos outros para chegar a bons termos em um acordo, não vão desejar realizar trocas entre si, exceto nas situações em são constituídas por transações padronizadas, e a especialização econômica nunca vai ocorrer".

$\mathrm{O}$ autor argumenta que o oportunismo deve ser constrangido por normas morais e a moralidade generalizada é ingrediente fundamental para o funcionamento efetivo dos mercados. Tal moralidade vai assegurar a honestidade do comércio mesmo na presença de players desonestos. Sem essa moralidade generalizada os mercados funcionarão com dificuldade.

MOORE (1994, apud HUMPRHEY \& SCHMITZ, 1998) enfatiza o papel dos mecanismos de reputação institucional e pessoal para sustentar o comércio. $\mathrm{O}$ argumento de que o 
mercado pode ser incrementado com a experiência das próprias transações de mercado está fundamentado nos efeitos da reputação. A desonestidade nas transações de negócios pode trazer ganhos imediatos, mas destrói a reputação e possíveis negócios futuros.

A questão central na confiança é a seguinte: se existe oportunismo, como encontrar parceiros confiáveis para as transações? ZUCKER (1986, apud HUMPRHEY \& SCHMITZ, 1998) identifica três formas de produção da confiança: baseada nas instituições; baseada em características e baseada no processo. A confiança produzida pelos meios institucionais encontra-se no nível macro. Nos EUA, por exemplo, a combinação de ondas de imigração, alto nível de mobilidade geográfica e uma alta taxa de nascimento e mortalidade de empresas, deteriora sistemas de transações baseados em etnia, reputação e experiência direta. Foram estabelecidas regras para ordenar os mercados e novas formas institucionalizadas de produção da confiança. Um sistema institucionalizado de regulação do mercado foi construído e surgiram agentes com informação sobre parceiros potenciais.

As instituições podem fornecer informações sobre os demais agentes. Por exemplo, as empresas geralmente buscam referências bancárias quando iniciam trocas com novos parceiros. A certificação também é forma de conhecer os parceiros potenciais.

No nível meso, a confiança baseada em característica aparece quando está ligada a uma pessoa, dependendo de fatores como histórico familiar e etnia. Nesse caso, a confiança do indivíduo é definida pela filiação a grupos que os agentes consideram confiáveis. O agente também pode ser membro do grupo, e tal identidade estabelece certas hipóteses comuns sobre a troca.

Outra forma de ocorrência da confiança no nível meso é a reputação, adquirida por empresas ou indivíduos por honestidade e competência técnica, que são reconhecidas por quem tem contatos mais próximos.

A confiança no nível micro é baseada na experiência de troca ou cooperação entre empresas específicas, chamada por ZUCKER de confiança baseada em processo. Essa forma é importante para transações interfirmas repetidas com freqüência, em dado período. O desenvolvimento dessa forma de confiança envolve dois elementos chave. Em primeiro lugar, as interações repetidas permitem que os parceiros entendam os 
motivos e prioridades uns dos outros. Em segundo lugar, a experiência das relações de troca indica a confiabilidade dos parceiros potenciais, até que ponto, os parceiros vão evitar trair o acordo, mesmo que possível.

A classificação das sanções e confiança em três níveis de agregação pode ser agrupada em dois níveis: externo, em que estariam aquelas de nível macro e meso (impessoal e setorial) e interno, em que estariam as de nível micro (personalizado).

\begin{tabular}{|c|c|c|c|}
\hline \multicolumn{2}{|c|}{ Nível de agregação } & \multirow{2}{*}{$\begin{array}{ll}\text { Sanções } \\
\text { Provisões e } \\
\text { restrições } \\
\text { contratuais } \\
\end{array}$} & \multirow{2}{*}{$\begin{array}{l}\text { Confiança } \\
\text { - Referências bancárias } \\
\text { - Certificação } \\
\end{array}$} \\
\hline $\begin{array}{l}\text { Economias } \\
\text { externas }\end{array}$ & $\begin{array}{l}\text { Nível macro } \\
\text { (impessoal) }\end{array}$ & & \\
\hline $\begin{array}{l}\text { (confiança } \\
\text { mínima) }\end{array}$ & $\begin{array}{l}\text { Nível meso } \\
\text { (grupo ou } \\
\text { setorial) }\end{array}$ & $\begin{array}{l}\text { - } \text { Regulação } \\
\text { setorial } \\
\text { - Perda de } \\
\text { reputação no } \\
\text { grupo }\end{array}$ & $\begin{array}{l}\text { - Reputação de honestidade e competência } \\
\text { - Confiança baseada em características } \\
\text { - Etnia } \\
\text { - Religião } \\
\text { - Gênero }\end{array}$ \\
\hline $\begin{array}{l}\text { Economias } \\
\text { Internas } \\
\text { (confiança } \\
\text { ampliada) }\end{array}$ & $\begin{array}{l}\text { Nível micro } \\
\text { (personalizado) }\end{array}$ & $\begin{array}{l}\text { Perda de } \\
\text { futuros } \\
\text { benefícios } \\
\text { da relação; } \\
\text { - Garantias }\end{array}$ & $\begin{array}{l}\text { - Confiança baseada no processo: } \\
\text { experiências de troca (cooperação) }\end{array}$ \\
\hline
\end{tabular}

Quadro 1 - Sanções e confiança (baseado em: HUMPHREY \& SCHMITZ, 1998).

Uma questão importante é a forma como as sanções e a confiança evoluem de acordo com a complexidade das relações. Em muitos casos, as sanções no nível macro são suficientes para sustentar a troca, a maior sanção é a lei. Quando as empresas têm segurança nas sanções básicas é possível estender algum grau de confiança, porque o nível de exposição ao risco é limitado pela sanção efetiva. Esse grau de confiança é chamado de confiança mínima.

Deve-se distinguir confiança mínima e confiança ampliada. A confiança mínima é aquela necessária para o bom funcionamento do mercado. A confiança ampliada se desenvolve quando as firmas criam interações mais complexas e interdependências. As relações mais cooperativas que ocorrem nos aglomerados de empresas necessitam de confiança ampliada. 
As nações mais desenvolvidas criaram sistemas de confiança ampliada. No mundo as empresas estão diminuindo o número de fornecedores, algumas vezes para metade do original (HUMPHREY \& SCHMITZ, 1998). O sistema de produção enxuta japonês é exemplo de confiança ampliada.

As transações entre fornecedores e clientes freqüentemente envolvem relações entre grandes e pequenas empresas, o que coloca as pequenas em situação de vulnerabilidade. É necessário, nesses casos, o desenvolvimento de instituições ou sanções legais que protejam os fornecedores. Na Alemanha as associações de indústrias e a regulação legal desempenham o papel de promover a confiança entre as empresas. Porém isso só é possível porque as empresas alemãs não concorrem em mercados sensíveis a preço, os clientes estão mais preocupados com competência técnica de seus fornecedores.

\subsubsection{Capacitação da mão-de-obra e dos empresários}

De acordo com MARSHALL, as vantagens de aglomeração das empresas são muitas para o contingente de mão-de-obra especializada.

"Os segredos da profissão deixam de ser segredos, e, por assim dizer, ficam soltos no ar, de modo que as crianças absorvem inconscientemente grande número deles. Apreciase devidamente um trabalho bem feito, discutem-se imediatamente os méritos de inventos e melhorias na maquinaria, nos métodos e na organização geral da empresa" (MARSHALL, 1982 p. 234).

\subsubsection{Indústrias correlatas e de apoio}

MARSHALL (1982 p. 234) chama a atenção para o surgimento de indústrias subsidiárias, "que fornecem à indústria principal instrumentos e matéria-prima, organizam seu comércio e, por muitos meios, lhe proporcionam economia de material."

A economia de escala e o uso e produção de maquinários especializados também é apontada pelo autor. Quando há "uma grande produção conjunta de uma mesma espécie" e indústrias subsidiárias que se dedicam "cada uma a um pequeno ramo do 
processo de produção", fornecendo para grandes empresas vizinhas, essas empresas subsidiárias "podem empregar continuamente máquinas muito especializadas, conseguindo utilizá-las rendosamente, embora o seu custo original seja elevado e sua depreciação muito rápida" (MARSHAL 1982 p. 234).

PORTER (1999) destaca as indústrias correlatas ou de apoio, como determinante de vantagens competitivas das regiões. Esse fator refere-se às empresas que abastecem o setor. Os produtores de máquinas e ferramentas japoneses buscam nos fornecedores que competem mundialmente produzindo unidades de controle numérico, motores e outros componentes. Já a Itália sustenta sua vantagem em calçados buscando em algumas indústrias fornecedoras insumos importantes e internacionalmente utilizados. Observa-se de modo geral que os setores de semicondutores, software e comércio exercem grande influência em outros setores.

O modelo de cadeia de valores ajuda a entender o conceito de indústrias correlatas. As empresas de um setor, ao competir, podem partilhar de atividades de sua cadeia de valor, por meio do desenvolvimento de tecnologia, manufatura, distribuição, comercialização ou assistência. $\mathrm{O}$ caso dos aparelhos de fax ilustra bem esse tipo de indústria. O domínio japonês na indústria de fax ocorreu pela similaridade de tecnologia e componentes com copiadoras que compartilham os mesmos canais de distribuição e assistência técnica.

De acordo com KRUGMAN (1994) uma indústria localizada pode oferecer suporte a mais fornecedores, que tornam essa indústria mais eficiente e reforçam a localização. Quando uma empresa faz investimento e compra insumos, aumenta o tamanho do mercado do fornecedor, induzindo mudança para uma escala de produção mais eficiente. Se não houver economias de escala, mesmo um centro de produção de pequena escala pode ser reproduzido em qualquer lugar com o mesmo grau de eficiência.

\subsection{Governança}

HUMPHREY \& SCHMITZ (2001) definem governança como a habilidade de determinados elos da cadeia em coordenar os vários atores e definir parâmetros sob os quais a cadeia opera. Os autores observaram que nas cadeias globais de suprimento, a racionalidade limitada e os custos das informações podem levar 
organizações a assumir o papel do mercado na coordenação das atividades econômicas. Essa análise de cadeia é importante devido a cinco aspectos básicos:

- $\quad$ são os elos mais fortes que têm acesso ao mercado;

- aumentam a capacitação das pequenas empresas nos processos produtivos, dado que estas aceleram sua curva de aprendizagem;

- $\quad$ são os elos que determinam a distribuição dos ganhos;

- $\quad$ são pontos de convergência de políticas públicas e

- fontes de assistência técnica especializada.

Os governantes da cadeia disseminam padrões produtivos e influenciam a definição de quatro grupos de parâmetros: $\underline{\mathrm{o}}$ que produzir, $\underline{\text { como }}$ produzir, quando produzir $\underline{\mathrm{e}}$ quanto produzir. Além disso, o preço é freqüentemente imposto por grandes clientes, mesmo que a teoria clássica assuma que o preço é determinado no mercado.

A governança pressupõe que algumas empresas da cadeia trabalhem segundo parâmetros impostos por outras. Isso exige que existam mecanismos de transmissão de informações e obediência a tais parâmetros.

GEREFFI (1994, apud HuMPHREY \& SCHMITZ, 2001) distingue dois tipos de atores que detém a governança: os produtores (producer driven) e os compradores (market driven). Quando a governança está com os produtores, os parâmetros são determinados por empresas que controlam a tecnologia, tanto do produto como do processo. Exemplo de governança dirigida pelo produtor ocorre na indústria automobilística Quando exercida por compradores, os parâmetros são estabelecidos por empresas varejistas e empresas detentoras de marcas, que focalizam no desenvolvimento de produtos e comercialização. Essas empresas freqüientemente não possuem plantas produtivas, como é o caso da Nike.

A definição de parâmetros também pode ser realizada por agentes externos à cadeia produtiva, como agências governamentais e organizações internacionais, por exemplo, as normas de segurança alimentar, normas para brinquedos, equipamentos elétricos, controle de produtos perigosos, entre outros (KAPLINSKY, 2000 apud HUMPHREY \& SCHMITZ, 2001). As normas podem ser relativas aos produtos e aos processos. 


\subsection{Economias internas}

As economias externas são variáveis que possuem ampla literatura na economia. O estudo das economias internas é menos freqüente, uma vez que ambientaria-se na Engenharia de Produção ou Administração de Empresas, essas disciplinas têm dado pouca atenção ao fenômeno da concentração geográfica de empresas. Os autores que se detiveram na observação das economias internas foram KRUGMAN, com o conceito de retornos crescentes de escala, PORTER, ao destacar o papel da rivalidade (competição) entre empresas de um APL e SCHMITZ ao observar as formas de cooperação entre empresas.

\subsubsection{Retornos crescentes de escala}

Baseado nos conceitos de MARShall, KrUgMAN (1991, 1994, 1995, 1996) afirma que a concentração geográfica tem origem na interação entre retornos crescentes, custos de transportes e demanda. É a interação entre economias de escala internas e demanda elástica que alavanca as economias externas (KRUGMAN, 1995). Entende-se por elástica uma demanda que aumenta quando o preço do produto é reduzido. Se as economias de escala são suficientemente grandes, cada produtor quer servir mercados geograficamente extenso a partir de uma localização (KRUGMAN, 1994). As economias de escala determinam altos custos fixos e baixos custos variáveis, entre eles os custos de transportes, o que possibilita alcançar localidades mais distantes de uma origem. Os retornos crescentes da escala são associados pelo autor às economias internas.

Para minimizar os custos de transportes, é escolhida localização com grande demanda local. Essa demanda será grande justamente onde a maioria das manufaturas escolher para se localizar. Isso implica circularidade que tende a manter um cinturão de manufatura.

SCHMITZ (1997) retoma o conceito de retornos crescentes de escala, que ocorrem quando aumento na quantidade de insumos provoca aumento mais que proporcional na quantidade produzida. Esses retornos foram negligenciados na literatura, pois se acredita que a tecnologia de informação e o advento da produção flexível reduziram as vantagens da escala. Isso não é necessariamente verdadeiro, dado que os produtores em um APL são muito especializados, dependendo da existência de 
outros fornecedores que produzem partes, componentes e equipamentos especializados. Quanto maior for o grau de especialização, maiores serão as economias de escala.

\subsubsection{Competição}

Uma outra fonte de economia interna nas empresas, destacada na literatura internacional, é o mix de cooperação e competição que ocorre nos APL's. A eficiência coletiva não pressupõe a ausência de competição, é o resultado de um processo em que algumas empresas crescem e outras declinam (SCHMITZ, 1995). Existe espaço para a cooperação em fases pré-competitivas ou entre fornecedores, que elevam o grau de eficiência interno das empresas.

PORTER (1999) destaca a estratégia das empresas como fonte de vantagem competitiva, em seu modelo diamante da competitividade. As estratégias, estruturas e rivalidades das empresas são as condições que definem o modo como as empresas são criadas, organizadas e dirigidas. No caso da Itália, onde a maior parte das empresas é de capital fechado, de pequeno e médio porte, familiar, observa-se que os setores mais bem sucedidos são aqueles que necessitam de flexibilidade e focalização em nichos, como a produção de calçados e confecções. Na Alemanha, os setores mais bem sucedidos são aqueles baseados em técnica e engenharia, como ótica e produtos químicos, de acordo com o perfil das grandes empresas hierarquizadas na organização e nas práticas gerenciais, que são a maioria no país.

Os objetivos das empresas, refletidos nas expectativas de remuneração do capital, influenciam a competitividade das regiões. Na Suíça e Alemanha bancos representam parcela substancial dos acionistas e as ações são negociadas a longo prazo, as empresas apresentam bom desempenho em setores maduros, em que são necessários investimentos em P\&D e novas instalações, com retornos moderados. Nos EUA a tradição no investimento de risco, com intensa negociação de ações no mercado, confere maior competitividade aos segmentos e setores novos, como software e biotecnologia. Os valores individuais definem as atividades mais prestigiadas em determinada região, como as indústrias farmacêutica e bancária na Suíça e a agricultura e defesa em Israel. 
A rivalidade local é fonte de estímulo para a competitividade. O principal exemplo é o do Japão, que apresenta inúmeras empresas nos setores em que é competitivo internacionalmente. Pesquisa realizada em 1987 identificou 112 empresas em máquinas ferramentas, 25 em equipamentos de som, 33 em construção naval, 34 em semicondutores .

PORTER é enfático na defesa da competição, contrapondo-se aos argumentos de que a competição pode levar à duplicação de esforços e dificultar a adoção de economias de escala, sendo totalmente contrário à concessão de subsídios estatais. Segundo o autor, a concessão de subsídios gera monopólios, como o setor aeroespacial e telecomunicações, nos EUA.

A rivalidade local pressiona o aumento da produtividade, com redução de custos, busca de inovações, melhoria da produtividade, uma vez que se torna atitude pessoal.

"Os concorrentes domésticos se envolvem em rixas acirradas, competem não apenas pela participação no mercado, mas também por pessoas, pela excelência técnica e, talvez, o mais importante, pelo "direito à bazófia" (PORTER, 1999 p. 192).

A competição doméstica também leva à busca de mercados externos, aumentando a rentabilidade. Quando os competidores domésticos são mundiais, a competição externa não requer grandes recursos e capacitações adicionais.

A adoção de inovações é facilitada pela proximidade geográfica e pressão competitiva. De acordo com PORTER (1999), nos aglomerados, as empresas percebem com mais clareza e rapidez, tanto as necessidades de seus compradores, como novas possibilidades tecnológicas, operacionais ou de distribuição. Além disso, os riscos para a adoção de inovações são menores nas concentrações geográficas.

"As empresas de um aglomerado têm condições de realizar experiências a custos mais reduzidos e de retardar maiores comprometimentos até que estejam mais seguras de que o novo produto, processo ou serviço será bem sucedido. Em contraste, a empresa que depende de fornecedores distantes enfrenta maiores desafios na contratação, na 
garantia de entrega, na obtenção de suporte técnico e de serviços e na coordenação entre as entidades complementares" (PORTER, 1999 p. 235).

\subsubsection{Cooperação}

SCHMiTZ $(1994,1995,1997)$ destaca a cooperação entre empresas, chamada de ação conjunta. Essas ações podem ser de dois tipos: cooperação bilateral, em que a cooperação ocorre entre empresas individuais (dividindo equipamentos ou desenvolvendo novo produto) e cooperação multilateral, quando grupos de firmas aglutinam forças em associações de negócios, consórcios de produção e outros. Também é possível distinguir a cooperação horizontal (entre competidores) da cooperação vertical (entre fornecedores de insumos e clientes). O Quadro 2 mostra as duas dimensões em conjunto.

As empresas compram produtos e serviços pelo mercado ou por arranjos de subcontratação. A natureza da relação pode variar de exploração à colaboração estratégica. $\mathrm{O}$ escopo para conflito pode ser maior horizontalmente porque os produtores geralmente competem por pedidos. A competição não exclui ações para resolver problemas específicos, particularmente em áreas pré-competitivas como provisão de serviços, infra-estrutura e treinamento. Dessa forma, o conceito de eficiência coletiva não nega o conflito ou competição entre as empresas do aglomerado. A concentração geográfica faz o mercado mais transparente e induz à rivalidade local. O aglomerado também facilita ações para resolver problemas comuns, diretamente, por meio de instituições de apoio, ou indiretamente, pelo governo local.

\begin{tabular}{||l|l|l||}
\hline & \multicolumn{1}{|c||}{ Bilateral } & \multicolumn{1}{|c||}{ Multilateral } \\
\hline \hline Horizontal & Compartilhar equipamentos & Associações setoriais \\
\hline Vertical & $\begin{array}{l}\text { Produtores e usuários melhorando } \\
\text { componentes }\end{array}$ & Alianças por meio de cadeia de valores \\
\hline
\end{tabular}

Quadro 2 - Sanções e confiança (baseado em: HUMPHREY \& SCHMITZ, 1998). Fonte: SCHMITZ, 1997. 


\section{MODELO CONCEITUAL DE EVOLUÇÃO DOS APL'S}

Os diversos modelos encontrados na bibliografia apresentam, como explicação ao fenômeno da concentração geográfica de empresas especializadas, a existência de economias externas e internas às empresas. As economias externas são economias incidentais, pois não dependem de decisões das empresas individuais e podem ter origem no mercado, na tecnologia e na organização social ou da produção. As economias internas dependem das decisões das empresas, ou seja, são intencionais e baseiam-se em e são baseadas em economias de escala, nos ganhos advindos da cooperação e os da competição entre empresas.

Portanto, a identificação de inúmeras vantagens da concentração de empresas não é novidade na literatura. Apesar disso, pouco se sabe sobre o papel dessas economias na formação, crescimento e manutenção de APL's. Em outras palavras, quais são suas causas, quais são suas conseqüências.

A evolução das diversas economias está intimamente ligada às trajetórias tecnológicas adotadas pelas empresas produtoras. A importância da tecnologia na competitividade dos APL's é apontada por diversos autores, o principal aspecto destacado, geralmente, é a existência de oferta de infra-estrutura de P\&D, originando concentrações de empresas em setores não tradicionais. O papel das inovações, trajetórias e ciclos de vida tecnológicos na competitividade dos APL's ainda não foi analisado e modelado.

\subsection{Origem dos APL's}

A hipótese básica sobre a origem dos APL's está na adoção de inovações radicais no processo que, combinadas com condições locais, criam novos paradigmas de produção, com economias de escala superiores àquelas existentes. As condições locais necessárias são a oferta de matéria-prima ou outros insumos, existência de capacitação em áreas correlatas e disponibilidade de capital social adequado (Figura 3). 


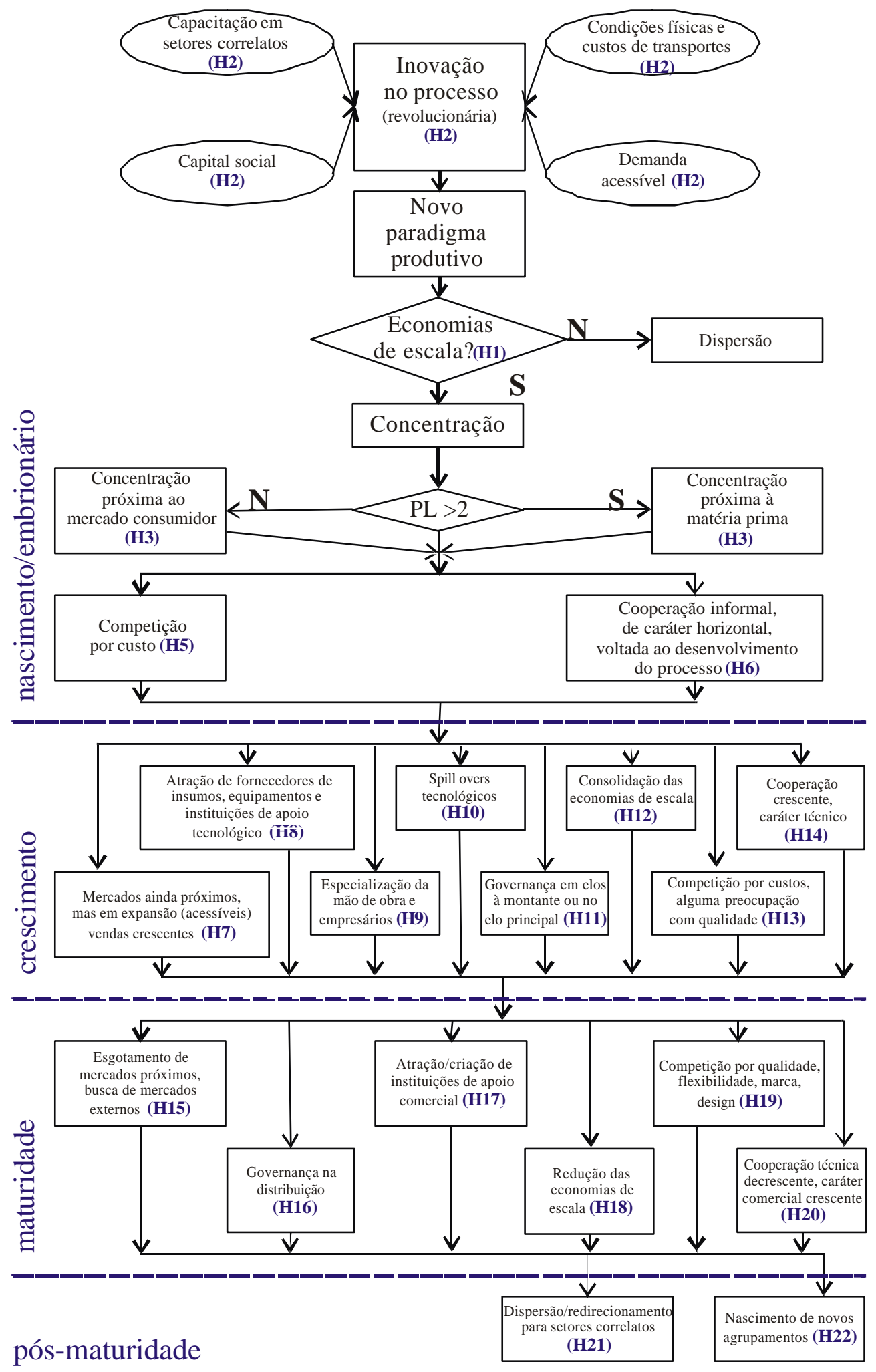

Figura 3 - Modelo conceitual de evolução dos APL's. 
Inicialmente, os APL's atenderiam demandas próximas e, ao evoluírem, passariam a atender mercados mais distantes. A estratégia competitiva das empresas inicia-se com a competição por custo, evoluindo para produtos de maior valor agregado.

\subsubsection{Economias de escala e concentração de empresas}

KRUGMAN (1994) apresenta raciocínio interessante em relação às causas fundamentais da concentração geográfica de empresas. Para o autor as economias de escala são a causa de todo o processo de concentração geográfica. Outros fatores seriam apenas decorrência do processo.

Em princípio, o autor descarta de sua análise os APL's dependentes de recursos naturais localizados, como a indústria do vinho que necessita de uvas frescas, produzidas em determinada localidade, por restrições de clima e solo. Nesse segmento incluem-se, entre outros, a mineração e a pesca.

A concentração geográfica de empresas geraria menor grau de risco, tanto para as empresas como para os trabalhadores. As empresas teriam menor chance de enfrentar escassez de trabalhadores; estes teriam menor chance de escassez de empregos. Em arranjos produtivos com muitos trabalhadores disponíveis, as eventuais quedas ou crescimentos na demanda por trabalhadores de uma empresa poderiam ser compensadas por movimentos contrários de outras empresas. Se as empresas se estabelecessem em locais distintos, cada uma delas teria disponível número reduzido de trabalhadores que, em parte, estariam desempregados, quando esta empresa reduzisse sua demanda por trabalho ou as empresas enfrentariam escassez de mãode-obra quando a demanda apresentasse crescimento.

A pergunta lapidar de KRUGMAN é: por que então o portfólio de empresas existentes em um grande aglomerado local não pode ser replicado em miniatura em várias localidades? Nesse caso, a um pequeno número de trabalhadores, corresponderia um conjunto de inúmeras pequenas empresas que deveriam reproduzir o mesmo comportamento estatístico do grande aglomerado de empresas, em termos das flutuações na demanda por trabalho de cada firma. A resposta de KRUGMAN para a questão é que pequenos portfólios não ocorrem devido à existência de economias de escala no processo produtivo que torna as pequenas plantas ineficientes. $\mathrm{O}$ mesmo raciocínio é aplicado para tratar do fornecimento de insumos intermediários. Por que 
os fornecedores de insumos intermediários se concentrariam no aglomerado de empresas? A resposta: economias de escala. Caso não existam economias de escala na produção do bem final, as plantas estariam espalhadas pelo espaço, provavelmente em função da proximidade com o mercado consumidor. Sem economias de escala na produção do insumo intermediário, as plantas destes também se localizariam desconcentradamente junto às empresas produtoras. Havendo economias de escala na produção do insumo, haveria estímulo à concentração geográfica em sua produção e, caso o custo de transporte do insumo fosse maior que o custo de transporte do bem final, haveria atração das empresas produtoras dos bens finais para as empresas produtoras dos insumos intermediários.

SOUZA e GARCIA (1999) argumentam que as descontinuidades nos sistemas produtivos dos setores tradicionais, como calçados e confecções é que estimulam o aparecimento de produtores especializados. Há dois tipos de produtores especializados, as gandes empresas e as pequenas. No caso do grande fornecedor, o fato de determinados processos serem mais caros se executados por um número grande de empresas e se tornarem mais econômicos se executados por uma empresa, que fornece a todas as outras, implica na existência de economias de escala no processo, como os curtumes, fornecedores da indústria calçadista. No caso da especialização de pequenos fornecedores, se observa que a terceirização evita que o produtor se envolva em atividades com deseconomias de escala, como é o caso das bancas de pesponto, na produção de calçados.

KRUGMAN não trata das economias de escala que podem ocorrer na comercialização final do produto, mas, seguindo o mesmo raciocínio, estas podem determinar a concentração de empresas. Esse fenômeno ocorre, particularmente, com produtos de baixo giro, como componentes eletrônicos especializados, luminárias e peças de decoração, malharia, entre outros.

Dessa forma, a hipótese de KRUGMAN é que a causa fundamental para a concentração geográfica de empresa residiria primordialmente nas economias de escala. A tendência de redução nos custos de transportes contribuiria para reforçar as vantagens de localização concentrada. Outros fatores de concentração geográfica de 
empresas, apontados por tantos outros autores, desde MARSHALL, seriam apenas conseqüência da concentração e não sua causa.

Os segmentos industriais que tem tendência à concentração geográfica, de acordo com a hipótese de KRUGMAN, devem apresentar economias de escala.

A manufatura de calçados, por exemplo, não apresenta, necessariamente, economias de escala. Em Franca, arranjo produtivo no estado de São Paulo, convivem empresas produtoras de até 10 pares de calçados por dia com empresas que produzem na casa dos cinco mil pares. Observa-se, contudo, dois elos com economias de escala evidentes: o curtimento do couro e a produção de solados de borracha.

Nos curtumes, o tratamento do couro com produtos químicos é feito por bateladas em reatores denominados fulões, de formato cilíndrico. Fulões maiores permitem economias de água, energia, agentes químicos, curtentes e mão-de-obra. Também passaram a ser importantes recentemente as economias de escala no tratamento de efluentes de processo.

A indústria de solados guarda grandes economias de escala em função do alto custo e produtividade dos equipamentos e dos altos investimentos em moldes, necessários, para a produção de solados de diferentes formatos e tamanhos. As vantagens de escala nessa indústria podem ser intuídas pela observação de clientes calçadistas dessas empresas, localizados em aglomerados distantes, como o de Novo Hamburgo, RS e outras localidades no Mercosul.

A indústria produtora de cerâmica tende a formar aglomerados, como Sassuollo na Itália, Castellón na Espanha, Criciúma em Santa Catarina e Santa Gertrudes em São Paulo. Esse segmento caracteriza-se por grandes economias de escala. O equipamento determinante da escala de produção é o forno de cozimento das peças, cujo comprimento chega a atingir 150 metros. Na década de 90 houve evolução na escala desses equipamentos, tendo sua capacidade ampliada de aproximadamente 80 mil $\mathrm{m}^{2} /$ mês para $500 \mathrm{mil} \mathrm{m} /$ mês. A compra de equipamentos modernos pelas empresas de Santa Gertrudes, pólo produtor no Estado de São Paulo, proporcionou economias de escala superiores aos demais APL's, o que resultou em grandes aumentos na produtividade e no crescimento observado na indústria local. 
As indústrias eletrônica e micro-eletrônica tendem a formar aglomerados industriais, em geral vinculados às instituições universitárias e de pesquisa. $\mathrm{O}$ principal insumo dessa indústria são recursos humanos qualificados, permanentemente atualizados que necessitam interação com grandes instituições de ensino e pesquisa tecnológica. Essas instituições necessitam altíssimos investimentos públicos e ampla interdisciplinaridade para que atinjam resultados de excelência, tanto no desenvolvimento de conhecimentos, quanto na formação de quadros técnicos. Em outras palavras, detém grandes economias de escala no seu processo. No Brasil esse fenômeno está sendo observado, por exemplo, no entorno da região de Campinas, SP. É preciso ainda verificar os reais fundamentos desse processo.

\subsubsection{Economias de escala e custos de transporte}

As economias de escala são determinadas pela relação entre custos fixos e custos variáveis. Os custos fixos referem-se ao tamanho das plantas e os custos variáveis incluem os insumos, matérias-primas, custos de transportes, distribuição e comercialização. Os custos de transportes dependem da distância até o centro consumidor, do peso do produto, da infra-estrutura de transportes, entre outros; e são custos definidos externamente às empresas. Analisando a relação entre custo de fixo e custo de transporte, observa-se que quanto menor o peso do custo de transporte (custo variável), maior é a economia de escala, maior é a tendência à concentração de empresas.

O custo de transporte depende da diferença entre o custo de transporte da matériaprima e do produto acabado. Alguns indicadores apresentados por WEBER (apud Clemente \& HigaCHI, 2000) como o Índice Material e Peso Locacional representam parcialmente os custos variáveis, influindo em sua relação com os custos fixos e nas economias de escala.

\subsubsection{Economias de escala e inovação revolucionária}

A origem dos APL's está sempre baseada em inovações revolucionárias que criam novos paradigmas produtivos com economias de escala extraordinárias, superiores às existentes em outros APL's. Mesmo que seja a adaptação de uma tecnologia existente às condições locais, pode-se que considerar que é uma inovação radical no 
processo, ou revolucionária, como definida por UTTERBACK \& ABERNATHY (1975), uma vez que muda o paradigma de produção existente.

O exemplo de Santa Gertrudes é típico deste processo de nascimento baseado na adoção de um novo paradigma produtivo com grandes economias de escala, aqui chamado inovação revolucionária. O processo via seca já estava disponível no mercado e era utilizado em algumas empresas. Porém, ao adaptá-lo à argila local, que também tinha baixo custo, foram criadas economias de escala que possibilitaram reduções nos custos de produção inviáveis anteriormente.

Outro exemplo interessante é o de Ibitinga, arranjo paulista produtor de artigos para cama e mesa. A origem da atividade econômica está no rabalho de uma bordadeira que veio da Ilha da Madeira e passou a comercializar artigos bordados, inicialmente com produção própria e depois ensinando o ofício a outras mulheres. Porém, a adaptação de máquinas de costura para automação do bordado foi o que possibilitou grandes economias de escala à produção de bordados na cidade e deu origem ao APL. Ou seja, foi no APL de Ibitinga que criou-se a máquina de bordar automatizada, por técnicos e empresários brasileiros, caracterizando-se numa típica inovação revolucionária.

\subsubsection{Condições locais e localização}

PORTER (1999) atribui as origens dos APL's às partes do diamante presentes na localidade. De fato, as condições de fatores como oferta de matéria-prima, especialização da mão-de-obra e infra-estrutura são atributos que podem reduzir os custos variáveis das empresas. A proximidade de uma demanda sofisticada atuaria reduzindo o custo de transporte. Essas condições são necessárias, mas não suficientes para o surgimento de um APL, pois se não houver economias de escala no processo produtivo, as empresas vão se localizar o mais próximo possível da demanda, se concentrando apenas quando a demanda também estiver concentrada, como nas metrópoles.

Os conceitos de peso locacional e índice material podem ajudar a compreender onde vai ocorrer a localização das empresas. Em síntese, haverá tendência para a localização dos APL's mais próximos à fonte de matérias-primas quando o peso locacional for alto - quando o peso (ou custo de transporte) da matéria-prima é 
superior ao peso (custo de transporte) do produto final. Exemplo desse caso é o dos APL's produtores de cerâmica de revestimento, que tendem a se localizar próximos às jazidas de argila, principal matéria-prima que compõe o produto.

Quando o peso locacional for baixo a tendência é pela localização mais próxima ao mercado consumidor. Como exemplo pode-se citar as produtoras de refrigerante, como a Coca-Cola, que traz o xarope da matriz e mistura a água em locais próximos aos grandes centros consumidores.

Outras condições são necessárias para a constituição de APL's - capital social, capacitação em áreas correlatas. Em outras palavras, o peso locacional não atua isoladamente para a determinação da localização.

Essa discussão ajuda a compreender o processo de localização dos fornecedores de insumos, matérias-primas e máquinas. A localização desses elos a montante vai depender, além de os custos de transportes, das estratégias e economias de escala na produção desses bens. Grandes economias de escala na sua produção podem definir localizações distantes do APL cliente. Todavia, custos de transportes (pesos locacionais) altos desses bens levam à localização próxima do APL cliente.

Contribuem para a localização próxima ao cliente, fornecimentos que demandam serviços agregados, como consultorias, manutenção, treinamento, desenvolvimentos conjuntos. Em geral, essas características estão presentes em processos novos ou ainda não amadurecidos, gerados por inovações revolucionárias, que são justamente as inovações indutoras da aglomeração de empresas. Conclui-se que na formação dos APL's se instalem, também, empresas fornecedoras de insumos, matérias-primas e máquinas.

No início, essas instalações podem ocorrer apenas por escritórios de representação ou revendas, mas, à medida que o APL evolui, o mesmo pode se tornar mais atraente para a fabricação local desses bens.

\subsection{Dinâmica dos APL's}

Além de os fatores determinantes do surgimento e localização dos APL's é preciso compreender de que forma as diversas vantagens competitivas, externas ou internas evoluem no tempo. 


\subsection{1. Área de influência}

Inicialmente, a demanda alcançada (área de influência) é a mais próxima (mercado local e regional). Quando mercado mais próximo é atendido, a área de influência passa a ser ampliada, são incorporados novos custos variáveis e os custos fixos têm sua importância reduzida.

Quando os custos variáveis de transportes e distribuição tornam-se mais relevantes, o crescimento da produção provoca aumento significativo nos custos. Nessas circunstâncias a competição por custos deixa de ser vantajosa, passando a prevalecer a competição por qualidade ou diferenciação. O crescimento da área de influência poderá justificar também a instalação de plantas fora do APL, mais próximas à demanda.

À medida que o APL amplia sua área de influência, a importância das economias de escala é diminuída provocando redução na atração de novas empresas.

\subsubsection{Os estágios de evolução dos APL's}

Ao observar diferentes APL's industriais, verifica-se que seu padrão de comportamento é, em geral, bastante diverso um em relação ao outro. Essas diferenças devem estar ligadas, eventualmente, a seus estágios de maturidade.

Propõe-se que a evolução dos APL's, de forma análoga aos setores industriais, pode ser dividida em quatro fases: nascimento/embrionário, crescimento, maturidade e pós-maturidade. Nessa última fase, pode ocorrer o declínio do APL ou haver mudança nas tendências para manter sua sustentabilidade.

\section{- Nascimento/embrionário}

No estágio inicial do APL há adoção de inovações revolucionárias com economias de escala significativas, associadas às condições locais como oferta de matériasprimas, insumos, capital social (confiança mínima), capacitação em setores correlatos e acesso a mercados sensíveis a custo. Nesse estágio não se observa a instalação de rede de fornecedores, quer com plantas produtivas ou representações comerciais mais ostensivas. A competição se dá por custo, sem nenhuma preocupação com a qualidade e a cooperação apresenta caráter informal, horizontal e 
técnico, sendo baseada em relações familiares ou de amizade. A cooperação vertical com fornecedores de equipamentos também se inicia de forma incipiente.

\section{- Crescimento}

$\mathrm{Na}$ fase de crescimento, os setores a montante passam a ser atraídos para o APL, seja na forma de representantes, seja com a instalação de plantas produtivas. A demanda crescente do APL possibilita aos fornecedores aumentarem sua produção e se beneficiarem das economias de escala que existam na produção desses bens.

A demanda crescente por mão-de-obra também induz a especialização em categorias profissionais, detentoras de conhecimento tácito sobre o processo produtivo. Esses conhecimentos são trocados a partir de processos informais vinculados a interações sociais. Disto decorre o surgimento de spin-offs, empregados que deixam as empresas produtoras para montar seus próprios negócios.

As economias de escala se consolidam a partir de uma série de inovações regulares, ou seja, inovações incrementais no processo, baseadas em tecnologias disponíveis.

A competição ainda se constrói por preço, os mercados atingidos ainda são próximos. Porém, já se verifica nesta fase alguma preocupação com qualidade. O objeto da cooperação tanto vertical quanto horizontal é, eminentemente, tecnológico. A cooperação vertical de caráter técnico com produtores de equipamentos se consolida, assim como com produtores de outros insumos importantes. A cooperação horizontal ainda de caráter bilateral e informal evolui até a formação de instituições de apoio. O suporte tecnológico é a principal missão das instituições de apoio, que passam também a ser atraídas para o APL. A governança se estabelece em elos à montante ou no elo principal da cadeia produtiva, dado que as economias de escala se estabelecem, majoritariamente, nesses elos.

No caso do Vale dos Sinos, APL produtor de calçados no Rio Grande do Sul, SCHMITZ (1995) identifica turning points e divide seu desenvolvimento em três períodos: 1. entre 1950 e 1968, 2. entre 1968 e 1987 e 3. após 1987. No primeiro período, a indústria de calçados do Vale dos Sinos cresceu e aumentou suas vendas com base no mercado interno. Nesse período, a maioria das empresas era de pequeno porte. Pode-se associar esta fase à fase de crescimento. 
As instituições de apoio tiveram papel importante na fase de crescimento, quando foi criada a Feira Nacional de Calcados de Novo Hamburgo FENAC (1963), escolas técnicas especializadas no curtimento do couro (1965), química e mecânica (1966), manufatura e design de calçados (1968) e o CTCCA (1972). A criação desses centros foi obtida graças à ação coletiva dos produtores locais. Esses centros têm participação importante do setor privado no seu financiamento.

\section{- Maturidade}

Na fase de maturidade, a estagnação dos mercados locais acirra a competição interempresarial, levando a uma redução das margens de comercialização em prol dos segmentos a jusante - distribuição e comercialização final. Esses passam a reter maiores margens, obtendo maior governança sobre a cadeia produtiva. A redução de margens no segmento produtivo pressiona as empresas líderes a buscar novos mercados, gerando crescimento das exportações. O atendimento a mercados distantes aumenta o volume de custos variáveis no produto final, dado que, além dos custos de transportes, alfandegários e distribuição, são incorporados custos de adaptação aos mercados externos. O crescimento dos custos variáveis reduz a importância relativa dos custos fixos e das economias de escala, implicando que a competição por custo passe a ser baseada em qualidade e flexibilidade ou marca, para compensar o crescimento dos custos.

Por conta da competição inter-empresarial a cooperação horizontal de cunho tecnológico tende a declinar, surgindo oportunidades para cooperação horizontal na área de comercialização do produto final. Surgem consórcios para exportação, marcas compartilhadas, exposição e feiras.

Em função da redução nas economias de escala, o APL já não vai atrair empresas produtoras. Esse fenômeno também torna viável economicamente a abertura de plantas fabris das maiores empresas em outras localizações, que apresentem vantagens no custo de produção ou de transporte para mercados mais distantes. Simultaneamente, observa-se que o processo produtivo torna-se mais codificado, permitindo a sua implementação em outras localizações sem o concurso de mão-deobra especializada. 
Tomando como exemplo novamente o Vale dos Sinos, ScHMITZ observa que, nessa fase, o APL passou a competir no mercado externo. As exportações tiveram origem tanto de contratos firmados por importadores que reconheceram as vantagens de comprar de empresas pertencentes a um APL estabelecido, com fornecedores locais especializados, como da ação coletiva para buscar pedidos externos. Além disso, os governos federal e estadual ajudaram na implementação de políticas de incentivos à exportação. O tamanho das empresas aumentou nesse período, sendo que 50 empresas tinham mais que 500 empregados, e algumas delas com mais de 1.000.

A fase inicial de significativa ação coletiva foi seguida de certa desintegração e desunião ocorrida entre meados da década de 70 até o final da década de 80. Até o final da década de 70, a associação comercial de Novo Hamburgo representou os interesses das empresas do Vale dos Sinos. Com o crescimento das exportações, o conflito de interesses cresceu: os produtores de calçados queriam acesso facilitado a insumos e equipamentos importados, enquanto os produtores locais eram contra. Além disso, as necessidades dos grandes empresas exportadoras eram diferentes das pequenas, que produziam para o mercado interno. Como resultado, se formaram cinco pequenas novas associações, para produtores de couro, componentes sintéticos, fornecedores de equipamentos e agentes exportadores e grandes calçadistas.

A cooperação vertical também diminuiu nesse período. Algumas das grandes empresas passaram a verticalizar a produção de determinados insumos. Houve também mudança na qualidade das relações na cadeia de suprimento. Até o final da década de 60, as relações entre fornecedores e consumidores eram facilitadas pelo fato de que todos eles pertenciam a mesma comunidade. A interação social reforçava a confiança e limitava o oportunismo. Durante o ápice de exportação, os negócios ficaram mais difíceis. A busca por lucros rápidos resultou na dificuldade de resolver conflitos.

\section{- Pós-maturidade ou rejuvenescimento}

A redução das economias de escala reduz a força centrípeta de agregação dos aglomerados industriais. Eles passam a enfrentar competição de outras localidades tanto nos mercados quanto pela emigração de empresas. 
Observa-se que as competências acumuladas pelos APL's permitem o desenvolvimento de novos negócios, com alto valor agregado. Assim, têm-se empresas industriais que passam apenas a gerenciar marcas de distribuição. Algumas desenvolvem máquinas, insumos e consultorias tecnológicas e de design. Também pode ocorrer o redirecionamento do APL para áreas correlatas, a partir da atuação em nichos de mercado e sempre a partir da implantação de economias de escala significativas.

Esses novos negócios podem dar novo impulso à atividade econômica local, se beneficiando das marcas e da reputação granjeada pelo aglomerado.

A indústria automobilística apresenta vários exemplos de APL na fase de pósmaturidade. A linha de montagem na produção de automóveis, inicialmente, viabiliza-se a partir de grandes lotes, gerando produtos, em princípio, indiferenciados. As mudanças ocorridas nas exigências da demanda, em termos de qualidade e diferenciação levaram a mudança paulatina do conceito de linha de montagem para produção globalizada de modelos adaptados a exigências locais. Sob esse novo paradigma produtivo as economias de escala são bem menos evidentes. Os automóveis podem ser montados localmente com peças e módulos produzidos em diferentes regiões. Consequentemente, grandes aglomerados da indústria automobilística no Brasil, como o $\mathrm{ABC}$, e Detroit nos EUA, vieram a perder sua relativa importância em relação à sua localização.

No caso do ABC paulista, pode-se afirmar que o arranjo automobilístico encontra-se em estágio bastante avançado de pós-maturidade. As competências locais acumuladas já podem ser observadas no desenvolvimento de novas atividades econômicas, como a indústria de transformados de plástico, ferramentaria, equipamentos mecânicos.

No Vale dos Sinos, observa-se duas ocorrências que marcaram a competitividade do APL: a entrada de produtos chineses no principal mercado consumidor externo (americano), com produtos de baixo valor agregado, e a mudança do padrão competitivo dos calçados brasileiros para produtos de maior qualidade. 
Os compradores americanos de calçados requisitam menores custos de estoque, sendo que os pedidos passam a ser colocados mais próximos aos pontos de venda, com menores prazos de entrega e lotes de menor volume.

A tendência de redução da cooperação vertical no Vale dos Sinos se reverteu parcialmente. Várias iniciativas foram tomadas para discutir coletivamente os problemas e realizar ações coordenadas, entre os vários elos da cadeia. Isso foi reforçado pelo Programa Brasileiro de Qualidade e Produtividade. 


\section{METODOLOGIA PROPOSTA PARA VALIDAÇÃO DO MODELO}

\subsection{Hipóteses e questões revisadas}

Retomando-se as premissas básicas, apresentadas no capítulo 1, sabe-se que a concentração geográfica de empresas acarreta vantagens competitivas em determinados setores e que a produção de cerâmica de revestimento é um dos segmentos que apresenta tendência à esse tipo de concentração.

Dessas premissas deriva-se a seguinte indagação: porquê, onde e como as empresas se concentram. Essa questão pode ser traduzida em três outras:

1. O que origina a concentração geográfica de empresas? (Por que?).

2. O que determina a localização dos agrupamentos? (Onde?).

3. Quais são e de que forma evoluem as vantagens competitivas das empresas concentradas geograficamente (Como?).

A partir da revisão bibliográfica e da proposição de um modelo conceitual, foram levantadas hipóteses quanto à origem e à evolução dos APL's. As hipóteses H1 a H3 são relativas à origem dos agrupamentos, a hipótese $\mathrm{H} 4$ é relativa à evolução dos APL's. A seguir são apresentadas as hipóteses genéricas.

H1 - As empresas concentram-se quando há economias de escala em algum elo da cadeia produtiva;

H2 - As economias de escala surgem de inovação revolucionária aliada a condições locais que permite a exploração eficiente destas economias, em paradigma de desempenho superior aos existentes;

H3 - O peso locacional e condições locais determinam onde a concentração irá ocorrer;

H4 - As vantagens competitivas apresentam evolução de acordo com os mercados atingidos, relações entre custos fixos e custos variáveis e estágio de evolução dos agrupamentos.

Tais hipóteses geram novas questões que devem ser aplicadas na validação do modelo para o APL de Santa Gertrudes. As perguntas inicias aplicadas à origem e evolução de Santa Gertrudes seriam as seguintes: 
Q4 - Existem economias de escala no segmento de cerâmica de revestimento?

Q5 - Qual é a origem do agrupamento de Santa Gertrudes?

Q6 - Por que as empresas escolheram Santa Gertrudes como localização?

Q7 - Em que fase de evolução está o APL de Santa Gertrudes?

A partir das hipóteses genéricas e das questões inicias específicas, novas questões são geradas. Com relação à origem são as seguintes questões:

Q8 - Qual inovação revolucionária criou economias de escala superiores às existentes?

Q9 - Quais eram as condições locais iniciais favoráveis, como oferta de fatores, capacitação da mão-de-obra, empresas correlatas e de apoio e capital social?

Q10 - Qual é o peso locacional da cerâmica de revestimento?

As perguntas relativas à fase de evolução são as seguintes:

Q11 - Como evoluíram as demais economias externas, como oferta de fatores, spin-offs tecnológicos, empresas correlatas e de apoio, capital social?

Q12 - As empresas do agrupamento trabalham com retornos crescentes de escala? (Qual é a relação entre custos fixos e custos variáveis?).

Q13 - Qual é a estratégia competitiva adotada pelas empresas de Santa Gertrudes?

Q14 - Qual é a natureza da cooperação no APL de Santa Gertrudes?

Ainda considerando as fases de evolução dos APL's, foram elaboradas as seguintes hipóteses com relação à evolução das economias internas e externas:

\section{- Fase embrionária}

H5 - A competição se dá exclusivamente por custo;

H6 - A cooperação tem caráter informal e majoritariamente horizontal, com base em relações familiares e de amizade.

\section{- Fase de crescimento}


As hipóteses para a fase de crescimento são as seguintes:

H7 - As vendas são crescentes e a área de influência do APL se amplia;

H8 - Inicia-se a atração de atores a montantes, ou seja, fornecedores especializados, como insumos, equipamentos e instituições de pesquisa e treinamento;

H9 - A mão de obra e os empresários passam a se especializar no novo sistema produtivo;

H10 - Ocorrem os primeiros spillovers tecnológicos, pela troca de informações e empregados que montam novas empresas;

H11 - A governança está com o elo principal ou elos a montante, dado que as vendas são crescentes;

H12 - Ocorre uma nova onda de inovações incrementais para a consolidação das economias de escala;

H13 - A competição ainda é predominantemente por custos, mas já aparece a preocupação com a qualidade;

H14 - A cooperação técnica vertical (com atores a montante) tem caráter crescente. A cooperação horizontal passa a ser formalizada e iniciam-se algumas tentativas de cooperação multilateral;

\section{- Fase de maturidade}

As principais características da fase de maturidade são a estabilização das vendas e redução na importância das economias de escala. Dado que as vendas se estabilizam há compressão nas margens e é necessário que o APL passe a ofertar produtos de maior valor agregado. As principais hipóteses nesta fase são:

H15 - Esgotamento dos mercados locais e início das exportações;

H16 - Atração de atores a jusante, ou seja, com maior impacto na comercialização;

H17 - Governança nos elos a jusante, onde passam a se concentrar as maiores margens de lucro; 
H18 -As economias de escala perdem importância;

H19 - O fator competitivo se desloca para qualidade, flexibilidade ou marca;

H20 - A cooperação técnica se estabiliza ou decresce, a cooperação comercial tem caráter crescente.

\section{- Fase de pós maturidade}

Nesta fase pode se dar o redirecionamento ou declínio do APL. As hipóteses para esta fase são:

H21 - Ocorre a dispersão das empresas do segmento principal, pode haver uma migração para um setor correlato;

H22 - Novos APL's irão surgir para atender, inicialmente os mercados mais distantes, e caso se consolidem, passam a disputar mercado com o APL original.

Para a verificação destas hipóteses foi feita uma pesquisa de campo no Arranjo Produtivo de Santa Gertrudes.

Esse esquema analítico é apresentado na (Figura 4). 


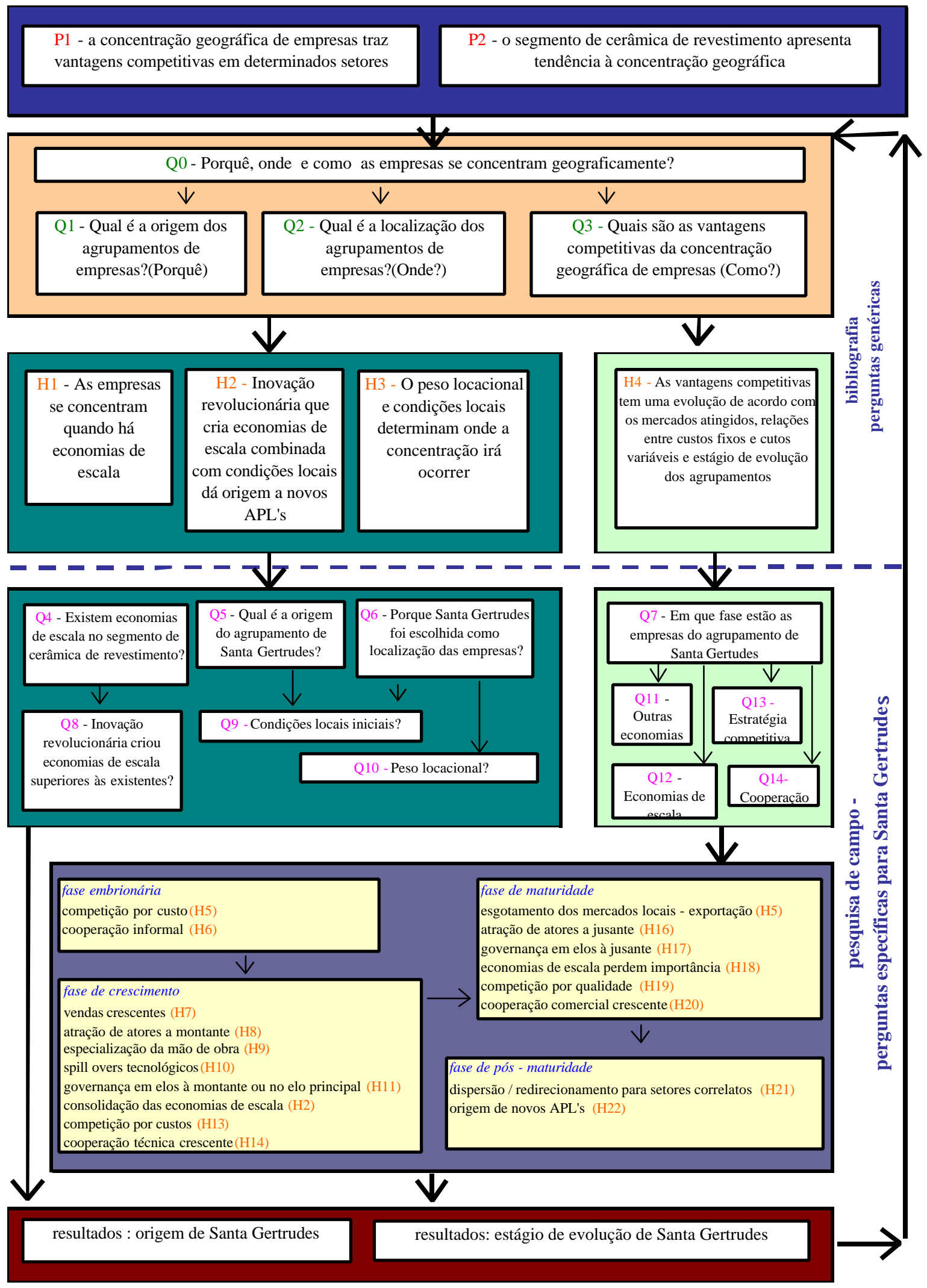

Figura 4 - Premissas (P), Questões (Q), Hipóteses (H) e Resultados (R). 


\subsection{Operacionalização dos conceitos}

Para responder as questões e verificar a pertinência das hipóteses, essas devem ser convertidas em variáveis, quantitativas e qualitativas.

O grau de complexidade das questões não é uniforme, o que requer classificação hierarquizada das variáveis. No primeiro nível, as variáveis são classificadas em economias externas e internas. No segundo nível as economias externas são classificadas em tecnológicas, de mercado e de organização. As economias internas são classificadas em economias de escala, estratégia competitiva e cooperação.

Algumas características importantes como área de influência, capital social não foram consideradas por dificuldades de obtenção de dados e mensuração.

O Quadro 3 mostra a hierarquia de classificação e as variáveis analisadas para cada pergunta de partida. 


\begin{tabular}{|c|c|c|c|c|c|}
\hline Questões de partida & Questões derivadas & $\begin{array}{c}\text { Categoria } \\
\text { nível 1 } \\
\end{array}$ & \begin{tabular}{|c|}
$\begin{array}{c}\text { Subcategoria } \\
\text { nível } 2\end{array}$ \\
\end{tabular} & \begin{tabular}{|c|}
$\begin{array}{c}\text { Subcategoria } \\
\text { nível } 3\end{array}$ \\
\end{tabular} & Variáveis \\
\hline \multirow{4}{*}{$\begin{array}{l}\mathrm{Q} 4 \text { - Existem } \\
\text { economias de escala } \\
\text { no segmento de } \\
\text { cerâmica para } \\
\text { revestimento? }\end{array}$} & \multirow{4}{*}{$\begin{array}{l}\text { Q8 - Inovação } \\
\text { revolucionária criou } \\
\text { economias de escala } \\
\text { superiores às existentes? }\end{array}$} & \multirow{4}{*}{$\begin{array}{l}\text { Economias } \\
\text { externas }\end{array}$} & \multirow{4}{*}{ Tecnologia } & \multirow{4}{*}{$\begin{array}{l}\text { Dinâmica } \\
\text { tecnológica }\end{array}$} & $\begin{array}{c}\text { Composição do } \\
\text { produto }\end{array}$ \\
\hline & & & & & \begin{tabular}{|l|} 
Processo produtivo \\
\end{tabular} \\
\hline & & & & & $\begin{array}{l}\text { Trajetórias } \\
\text { tecnológicas }\end{array}$ \\
\hline & & & & & $\begin{array}{c}\text { Inovação } \\
\text { revolucionária }\end{array}$ \\
\hline \multirow{6}{*}{$\begin{array}{l}\text { Q5 - Qual é a origem } \\
\text { do agrupamento de } \\
\text { Santa Gertrudes }\end{array}$} & \multirow{6}{*}{$\begin{array}{l}\text { Q9 - Quais eram as } \\
\text { condições locais iniciais } \\
\text { favoráveis? }\end{array}$} & \multirow{6}{*}{$\begin{array}{l}\text { Economias } \\
\text { externas }\end{array}$} & \multirow{3}{*}{ Tecnologia } & \multirow{3}{*}{$\begin{array}{l}\text { Condições } \\
\text { físicas }\end{array}$} & $\begin{array}{c}\text { Oferta de matéria- } \\
\text { prima }\end{array}$ \\
\hline & & & & & Oferta de energia \\
\hline & & & & & $\begin{array}{l}\text { Custos de } \\
\text { transportes }\end{array}$ \\
\hline & & & Organização & Capacitação & $\begin{array}{l}\text { Contingente de } \\
\text { mão-de-obra e } \\
\text { empresários }\end{array}$ \\
\hline & & & & Empresas & Cadeia produtiva \\
\hline & & & Organização & \begin{tabular}{|c|}
$\begin{array}{c}\text { correlatas e de } \\
\text { apoio }\end{array}$ \\
\end{tabular} & Governança \\
\hline \multirow{6}{*}{$\begin{array}{l}\text { Q6 - Por que as } \\
\text { empresas escolheram } \\
\text { Santa Gertrudes para } \\
\text { localização? }\end{array}$} & Q10 - Peso locacional & $\begin{array}{l}\text { Economias } \\
\text { externas }\end{array}$ & Tecnologia & $\begin{array}{l}\text { Dinâmica } \\
\text { tecnológica }\end{array}$ & Peso locacional \\
\hline & \multirow{9}{*}{$\begin{array}{l}\text { Q11 - Outras economias } \\
\text { externas (atuais) }\end{array}$} & \multirow{2}{*}{$\begin{array}{c}\text { Economias } \\
\text { externas }\end{array}$} & \multirow{2}{*}{ Mercado } & \multirow{2}{*}{ Demanda } & Internacional \\
\hline & & & & & Nacional e regional \\
\hline & & Economias & Mercado & Concorrência & Internacional \\
\hline & & externas & & & Nacional e regional \\
\hline & & $\begin{array}{c}\text { Economias } \\
\text { externas }\end{array}$ & Tecnologia & $\begin{array}{l}\text { Dinâmica } \\
\text { tecnológica }\end{array}$ & Idem \\
\hline \multirow[t]{4}{*}{$\begin{array}{l}\text { Q7 - Fase de evolução } \\
\text { do agrupamento }\end{array}$} & & \multirow{4}{*}{$\begin{array}{l}\text { Economias } \\
\text { externas }\end{array}$} & Tecnologia & $\begin{array}{c}\text { Condições } \\
\text { físicas }\end{array}$ & Idem \\
\hline & & & Organização & \begin{tabular}{|l|} 
Capital social \\
\end{tabular} & Idem \\
\hline & & & Organização & Capacitação & Idem \\
\hline & & & Organização & \begin{tabular}{|c|} 
Empresas \\
correlatas e de \\
apoio \\
\end{tabular} & Idem \\
\hline \multirow{13}{*}{$\begin{array}{l}\text { Q7 - Evolução do } \\
\text { agrupamento }\end{array}$} & $\begin{array}{l}\text { Q12 - Economias de } \\
\text { escala nas empresas }\end{array}$ & $\begin{array}{l}\text { Economias } \\
\text { internas }\end{array}$ & $\begin{array}{c}\text { Economias de } \\
\text { escala }\end{array}$ & $\begin{array}{c}\text { Economias de } \\
\text { escala }\end{array}$ & Economias de escala \\
\hline & \multirow{7}{*}{$\begin{array}{l}\text { Q13 - Estratégia } \\
\text { competitiva das empresas }\end{array}$} & \multirow{7}{*}{$\begin{array}{l}\text { Economias } \\
\text { internas }\end{array}$} & \multirow{7}{*}{$\begin{array}{l}\text { Estratégia } \\
\text { competitiva }\end{array}$} & \multirow{3}{*}{ Mercado } & Preço do produto \\
\hline & & & & & $\begin{array}{l}\text { Fator crítico de } \\
\text { sucesso }\end{array}$ \\
\hline & & & & & Mercado atingido \\
\hline & & & & \multirow{4}{*}{ Produção } & Sistema de produção \\
\hline & & & & & \begin{tabular}{|l|} 
Sistema de inovação \\
\end{tabular} \\
\hline & & & & & Mão-de-obra \\
\hline & & & & & Financiamento \\
\hline & \multirow{5}{*}{$\begin{array}{l}\text { Q14 - Natureza da } \\
\text { Cooperação }\end{array}$} & \multirow{5}{*}{$\begin{array}{l}\text { Economias } \\
\text { internas }\end{array}$} & \multirow{5}{*}{ Cooperação } & \multirow{2}{*}{$\begin{array}{c}\text { Cooperação } \\
\text { horizontal }\end{array}$} & Bilateral \\
\hline & & & & & \begin{tabular}{|c|} 
Multilateral \\
\end{tabular} \\
\hline & & & & \multirow{3}{*}{$\begin{array}{l}\text { Cooperação } \\
\text { vertical }\end{array}$} & Bilateral a montante \\
\hline & & & & & Bilateral a jusante \\
\hline & & & & & Multilateral \\
\hline
\end{tabular}

Quadro 3 Classificação das variáveis x questões de pesquisa. 


\subsection{Estratégia de pesquisa}

O estudo de caso é a estratégia mais adequada para a pesquisa proposta devido a três razões básicas:

a) as perguntas de partida são do tipo como e por que;

b) não é possível controlar os eventos observados; e

c) o fenômeno não pode ser separado de seu contexto.

De acordo com YIN (1991), as perguntas de partida do tipo como e por que são mais adequadas ao estudo de caso pois "lidam com ligações operacionais que necessitam ser desenhadas em determinado período de empo e não meramente freqüências ou incidências". A unidade de análise é o APL de Santa Gertrudes. Outro fator que favorece o estudo de caso é a dificuldade em estabelecer limites entre o objeto de análise e o meio ambiente. Apesar disso, a classificação das vantagens competitivas em economias externas e economias internas facilita a coleta de dados e a análise das informações.

A coleta de dados foi realizada a partir de dados primários e secundários. Os dados primários foram obtidos com entrevistas localizadas com empresários e especialistas do setor. Os dados secundários devem ser obtidos a partir de bases de dados disponíveis, e estudos de casos nos APL's da Itália, Espanha e Santa Catarina.

\subsection{Pesquisa de campo}

A pesquisa de campo foi realizada com empresas e especialistas do segmento. ${ }^{1}$ As entrevistas com as empresas cerâmicas de Santa Gertrudes e com os colorifícios sediados em São Paulo, ou com representação local, foram baseadas em questionários. As entrevistas com os produtores de equipamentos, distribuidores, outros atores da cadeia produtiva e empresas líderes em Santa Catarina foram baseadas em roteiros menos estruturados que os questionários, em que foram colocadas questões específicas. Também foram realizadas entrevistas com a

\footnotetext{
${ }^{1}$ A pesquisa de campo que se baseou este trabalho foi realizada no período entre maio e julho de 2001, no âmbito de um projeto realizado pela DEES (Divisão de Economia e Engenharia de Sistemas) e DIGEO (Divisão de Geologia) do IPT e financiado pela SCTDET (Secretaria de Ciência, Tecnologia, Desenvolvimento Econômico e Turismo do Estado de São Paulo). As entrevistas foram sempre realizada por no mínimo dois pesquisadores do IPT.
} 
ANAMACO (Associação Nacional dos Fabricantes de Materiais de Construção), que representa o elo de distribuição, entrevistas com Associações de Classe (Sindicato das Indústrias de Construção e Mobiliário de Santa Gertrudes e ASPACER Associação Paulista de Cerâmica de Revestimento) e instituições de pesquisa e apoio (CCB - Centro Cerâmico do Brasil, ABC - Associação Brasileira de Cerâmica, UFSCar - Universidade Federal de São Carlos - Departamento de Materiais, SENAI - Serviço Nacional de Aprendizagem Industrial, IPT - Instituto de Pesquisas Tecnológicas de São Paulo - Divisões de Química e Civil), conforme apresentado no Quadro 4.

\begin{tabular}{||l|l|l||}
\hline \multicolumn{1}{|c|}{ Elo } & \multicolumn{1}{|c|}{ Entrevistados } & \multicolumn{1}{|c||}{ Instrumento } \\
\hline \hline Empresas cerâmicas & $\begin{array}{l}6 \text { empresas em Santa Gertrudes } \\
2 \text { empresas em Criciúma }\end{array}$ & $\begin{array}{l}\text { Questionário } \\
\text { Roteiro }\end{array}$ \\
\hline Mineradoras & $\begin{array}{l}2 \text { independentes } \\
2 \text { mineradoras vinculadas } \\
1 \text { central de massa }\end{array}$ & Questionário \\
\hline Colorifícios & $\begin{array}{l}3 \text { fabricantes } \\
2 \text { representantes }\end{array}$ & Questionário \\
\hline Fabricantes de máquinas & $\begin{array}{l}2 \text { fabricantes } \\
1 \text { representante } \\
1 \text { ex- fabricante }\end{array}$ & Roteiro \\
\hline Instituições de Apoio e \\
pesquisa & $\begin{array}{l}\text { Sindicato } \\
\text { ASPACER } \\
\text { IPT } \\
\text { UFSCar } \\
\text { SENAI - Mário Amato }\end{array}$ & Roteiro \\
\hline $\begin{array}{l}\text { Distribuição e } \\
\text { assentamento }\end{array}$ & $\begin{array}{l}\text { ANAMACO } \\
\text { SENAI - Orlando Laviero Ferrajuolo }\end{array}$ & Roteiro \\
\hline \hline
\end{tabular}

Quadro 4 - Entrevistas realizadas para a pesquisa de campo.

${ }^{1}$ A pesquisa de campo que se baseou este trabalho foi realizada no período entre maio e julho de 2001, no âmbito de um projeto realizado pela DEES (Divisão de Economia e Engenharia de Sistemas) e DIGEO (Divisão de Geologia) do IPT e financiado pela SCTDET (Secretaria de Ciência, Tecnologia, Desenvolvimento Econômico e Turismo do Estado de São Paulo). As entrevistas foram sempre realizada por no mínimo dois pesquisadores do IPT. 


\section{O SEGMENTO DE CERÂMICA DE REVESTIMENTO}

\subsection{Dinâmica Tecnológica}

\subsubsection{Produto}

A cerâmica para revestimento, ou placa cerâmica, é material de construção civil utilizado para cobrir e dar acabamento a superfícies lisas, em ambientes industriais, comerciais, residenciais e em locais públicos. Nessa categoria enquadram-se pisos, azulejos, ladrilhos e pastilhas. Como produtos substitutos destacam-se a madeira, o vinil, os carpetes, entre outros materiais.

As principais vantagens da cerâmica para revestimento em relação a outros produtos são a durabilidade, a resistência mecânica, a facilidade de limpeza, a resistência à água e ácidos, não ser inflamável, ser higienicamente inerte e inorgânico, e não ter limites para o desenho estético em sua superfície (LEMOS e VIVONA, 2002).

As placas cerâmicas são constituídas, em geral, de três camadas: a) o suporte ou biscoito, b) o engobe, que tem função impermeabilizante e garante a aderência da terceira camada, e c) o esmalte, camada vítrea que também impermeabiliza, além de decorar uma das faces da placa.

A cerâmica contêm matérias-primas naturais e sintéticas. O corpo cerâmico compõese de matérias-primas naturais, argilosas e não argilosas. Os materiais argilosos são formados de uma mistura de diversos tipos e características de argilas para dar a composição desejada e são a base do biscoito. Os materiais não argilosos, quartzo, feldspato e caulim, servem para sustentar o corpo cerâmico ou promover a fusão da massa. Os materiais sintéticos são utilizados para a produção de esmaltes e engobes.

Os tipos de placas cerâmicas são classificados formalmente em classes de absorção d'água do suporte, o que determina seu uso. As placas com menor grau de absorção de água, são recomendadas para pisos externos que sofrerão grandes esforços durante sua utilização, como locais públicos, shopping centers, aeroportos e escolas. Esse é o caso do grés-porcelânico. As placas com maior grau de absorção são os azulejos, que devem ser utilizados em paredes internas, pois a absorção d'água facilita o assentamento. 


\begin{tabular}{l|c|c|c|c}
\hline \hline $\begin{array}{c}\text { Tipologia } \\
\text { Cerâmica }\end{array}$ & $\begin{array}{c}\text { Absorção de } \\
\text { Água (\%) }\end{array}$ & $\begin{array}{c}\text { Grupo } \\
\text { ISSO }\end{array}$ & $\begin{array}{c}\text { Carga de Ruptura e } \\
>7,5 \mathrm{~mm}(\mathrm{~N})\end{array}$ & $\begin{array}{c}\text { Módulo de Ruptura } \\
\left(\mathrm{N} / \mathrm{mm}^{2}\right)\end{array}$ \\
\hline \hline Grés Porcelânico & $0,0-0,5$ & Ia & $>1.300$ & $>35$ \\
\hline Grés & $0,5-3,0$ & Ib & $>1.100$ & $>30$ \\
\hline Semi-Grés & $3,0-6,0$ & IIa & $>1.000$ & $>22$ \\
\hline Semi-Poroso & $6,0-10$ & Ilb & $>900$ & $>18$ \\
\hline Piso-Poroso & $10-20$ & III & $>600$ & $>15$ \\
\hline Azulejo & $10-20$ & III & $>400$ & $>12$ \\
\hline Azulejo Fino & $10-20$ & III & $>200$ & $>15$ \\
\hline \hline
\end{tabular}

Tabela 1 - Tipologia de placas cerâmicas quanto a absorção de água, carga e módulo de ruptura (ABNT 1997).

Além do grau de absorção e da resistência mecânica, outras características técnicas necessárias são a resistência à abrasão superficial, resistência a manchas e ácidos, resistência ao choque térmico estabilidade de cores e estabilidade dimensional (MARTINS et al., 2001).

\subsubsection{Estrutura de custos}

A estrutura de custos da produção de cerâmica foi obtida a partir de entrevistas com empresários e estudo de GORINI \& CORRÊA (1999). A matéria-prima é o principal item de custo com participação de $31 \%$ no total, seguida mão-de-obra (19\%). , O custo de transportes é de $17 \%$ do total; combustíveis e energia são $15 \%$. O item “outros", responsável por $18 \%$, agrupa os custos que não puderam ser estimados com maior precisão, como depreciação e impostos. (Figura 5). 


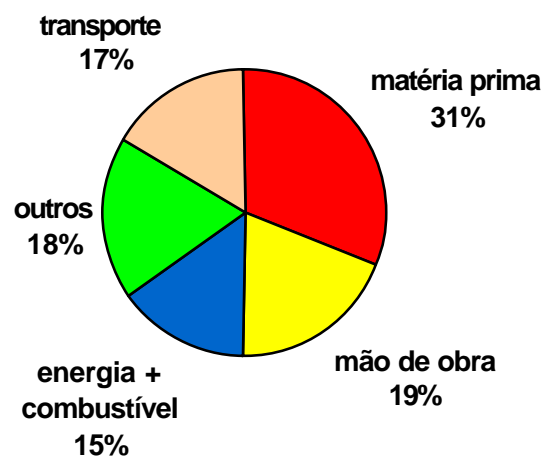

Figura 5 - Estrutura genérica dos custos de produção em Santa Gertrudes.

Fonte: Baseado em GORINI \& CORRÊA (1999) e entrevistas com especialistas e empresários.

\subsubsection{Peso locacional}

O peso locacional da cerâmica de revestimento é 2,21 , dado que existe perda de peso de aproximadamente $20 \%$ da matéria-prima para o produto acabado.

$$
\begin{aligned}
& \mathrm{Pl}=\mathrm{IM}+1 \\
& \mathrm{IM}=\mathrm{Pmp} / \mathrm{Ppf} \\
& 1 \text { ton } \mathrm{mp}=55 \mathrm{~m}^{2} \text { de piso } \\
& 1 \mathrm{~m}^{2} \text { piso }=13-15 \mathrm{~kg} \\
& 55 \mathrm{~m}^{2}=825 \mathrm{~kg} \\
& \mathrm{IM}=1000 / 825=1,212121 \\
& \mathrm{PL}=2,212121
\end{aligned}
$$

\subsubsection{Processo produtivo}

O processo de produção de cerâmica de revestimento se inicia na mineração, atividade responsável pelo fornecimento de matéria-prima, em que é realizada a 
extração de argila; pré-beneficiamento em pátio e transporte da matéria-prima. Essa atividade é feita fora da planta de produção, mesmo em empresas verticalizadas.

Na planta de produção cerâmica, a matéria-prima é misturada para a preparação da massa. O processo de moagem da mistura apresenta duas tecnologias diferentes: via úmida e via seca. Na via úmida, após a moagem é feita a atomização. $\mathrm{Na}$ via seca, é feita umidificação. A massa resultante da moagem segue, então para a compactação em prensas automatizadas de grande porte, formatando as placas. Ocasionalmente, pode ser conformada por processo de extrusão, na busca de produtos especiais, tais como peças de alta resistência e placas rústicas. Uma vez conformada, é feita a secagem da placa para redução da umidade. O processo de acabamento é iniciado com a aplicação do engobe, seguido de serigrafia e esmalte.

Após aplicação do esmalte é então realizada a queima, em fornos de rolo, com processo contínuo de alimentação. O tempo de permanência é de 25 a 30 minutos, com temperaturas máximas de $1.100{ }^{\circ} \mathrm{C}$. Em seguida, as placas são classificadas, inspecionadas e expedidas. Peças mais sofisticadas podem passar por segunda ou terceira queima, para a introdução de pigmentos que necessitem de temperaturas mais baixas para queima.

As linhas de produção são automatizadas e sofisticadas, pois se tratam de equipamentos ou pacotes tecnológicos atualizados, geralmente fabricados na Itália, que fornecem alta produção de placas cerâmicas. Cada linha nova produz em escala de 300.000 a $400.000 \mathrm{~m}^{2} /$ mês, enquanto as antigas estão por volta de 120.000 $\mathrm{m}^{2} / \mathrm{mês}$.

A Figura 6 mostra o processo produtivo das placas prensadas. 


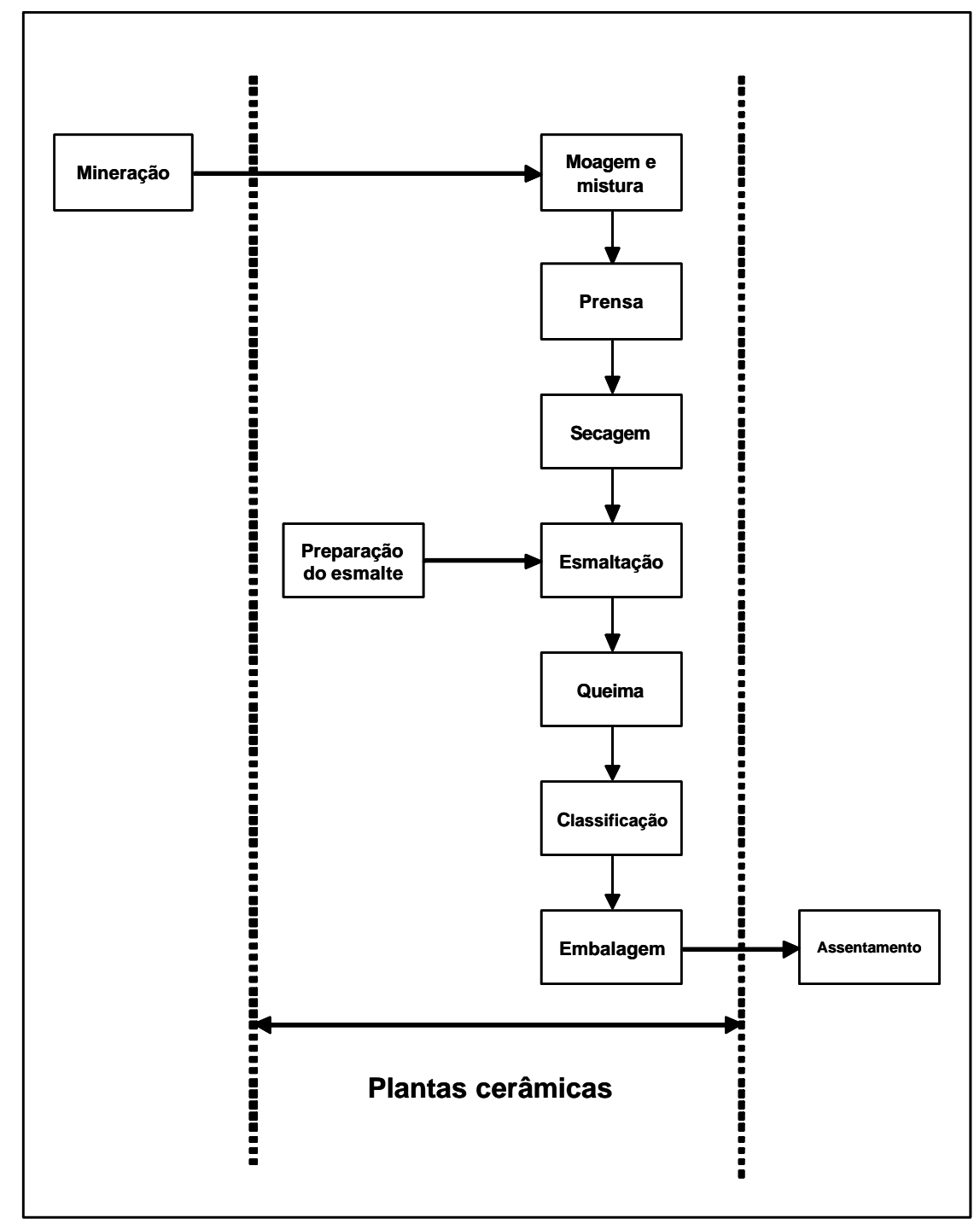

Figura 6 - Fluxograma do processo de produção de cerâmica de revestimento.

Além de os moinhos, fornos e prensas, os principais equipamentos utilizados, em maioria automatizados, são os dosadores, os secadores, os atomizadores (via úmida) e umidificadores, as correias transportadoras, os equipamentos de esmaltação e serigrafia, os medidores de bitola e calibre e as máquinas de paletização.

\subsubsection{Trajetórias tecnológicas}

Duas fases do processo de produção apresentam paradigmas alternativos que acarretam ganhos de escala extraordinárias: o processo de queima e a fase de moagem e mistura. $\mathrm{O}$ primeiro, pode ser feito em uma, duas ou três queimas. $\mathrm{O}$ segundo pode ser feito por via úmida e via seca. 
- Monoqueima x biqueima

Introduzido na Itália, no início dos anos 70, o processo de monoqueima foi uma das mais importantes inovações revolucionárias na indústria de cerâmica de revestimento. No processo de biqueima, em que são utilizados dois fornos, a peça é prensada e levada para cozimento em temperaturas entre $1050{ }^{\circ} \mathrm{C}$ e $1100{ }^{\circ} \mathrm{C}$. Em seguida, a peça é transportada por correias até as máquinas de esmaltação e serigrafia para a aplicação de esmaltes e decoração. Após decoração as peças passam pela segunda queima, para vitrificar o esmalte e estabilizar as cores (BELTRAME, 1998; ROMERO, 1994).

No processo de monoqueima, após prensagem, as peças seguem diretamente para a linha de esmaltação e serigrafia, para depois passar por uma queima, obtendo-se a sinterização do corpo cerâmico e a vitrificação do esmalte.

As principais vantagens da monoqueima em relação à biqueima são a redução no uso de energia, no tempo de ciclo e na mão-de-obra requerida.

- Moagem úmida x moagem seca

No processo de moagem pela via seca são utilizados moinhos de martelo e pendulares e a mistura utiliza apenas dois ou três tipos de argila. Depois da moagem, a mistura segue para umidificação para alcançar o grau de umidade necessário. A argila utilizada no processo via seca confere ao produto a cor vermelha. A placa produzida por via seca tem absorção de água variando entre 6 e 10\% (Grupo BIlb). As principais vantagens desse processo são o menor consumo de energia e mão-deobra, menor necessidade de estoques de matérias-primas.

No processo via úmida, os materiais são misturados com água e triturados em moinhos de bolas (seixos) buscando redução das partículas a dimensões microscópicas. Em seguida, a mistura é pulverizada em presença de ar quente, no processo de atomização, para a redução do teor de umidade e obtenção da granulometria adequada para os processos subsequientes. A massa é composta de uma mistura mais complexa de matérias-primas, geralmente de cor clara ou não vermelha, não havendo identificação com o grupo de absorção de água. O resultado é massa mais homogênea, que apresenta maior produtividade ras prensas e um produto com maior resistência mecânica (BELTRAME, 1998). 
- Outras tendências

A transformação do processo produtivo por bateladas para contínuo foi outra grande inovação revolucionária, pois permitiu a redução do consumo energético e de mãode-obra (ROMERO, 1994).

As prensas tiveram sua capacidade ampliada de aproximadamente 1.000 toneladas, na década de 80 , para as atuais prensas de 7.000 toneladas, utilizadas para a produção de grés-porcelanato. Isso permitiu que se ampliassem também as dimensões das placas e reduzisse sua espessura. Na Ceramics Technology Fair de outubro de 2000, em Munique, a empresa italiana System lançou novo produto chamado de Lamina, com espessura de apenas $3 \mathrm{~mm}$ (a menor espessura dos revestimentos cerâmicos convencionais é de $6 \mathrm{~mm}$ ) (MEYER-STAMER et al., 2000 p. 25-26).

O processo de queima é alvo de constantes melhorias. No início dos anos 80 foram introduzidos os queimadores de alta velocidade no processo biqueima, permitindo a redução dos tempos de ciclo de 60 horas para 35-40 horas (BELTRAME, 1998).

$\mathrm{Na}$ monoqueima, os tempos de ciclo são cada vez mais reduzidos a partir de lançamento de fornos a rolos e o sistema ITP - Integral Thermal Process, lançado em 1986, na Itália. Atualmente, buscam-se fornos mais rápidos e compridos visando a redução do consumo térmico conseguindo obter tempos de ciclo muitas vezes inferiores a 30 minutos (BELTRAME, 1998; ARAÚJO et al., 2001).

"Outras tendências tecnológicas observadas são os lançamentos de secadores com maior capacidade para absorver a produção das prensas (verticais ou horizontais), as linhas de esmaltação mais flexíveis, a substituição de esmaltação a disco por campanas, as máquinas serigráficas rotativas, a impressão flexográfica” (BELTRAME, 1998).

\subsection{Mercado}

A evolução do nercado de cerâmica de revestimento também pode ser dividida em fases, identificando-se três diferentes padrões de comportamento. Na década de 60, a Itália passa a desenvolver uma indústria, antes baseada em manufatura quase artesanal. Estabelece hegemonia na década 70, a partir de ganhos de escala 
significativos. Na década de 80 a Espanha passa a competir com a Itália, na década de 90, outros países como Brasil, Indonésia, Turquia, México e principalmente a China se tornam produtores importantes. A significativa expansão da produção na década de 90 com a entrada de novas regiões produtoras, deve-se, principalmente, à expansão do consumo nos países do Terceiro Mundo, que apresentam maiores taxas de crescimento que os países europeus. O consumo de cerâmica, nesses países, está ligado ao aumento da renda, que eleva o crescimento da produção habitacional, principal cliente da indústria de cerâmica de revestimento.

A China atualmente destaca-se por ser a principal produtora, com participação de $29 \%$ no total do volume mundial. Essa produção é quase totalmente consumida pelo próprio país, sendo que apenas $3 \%$ é exportado. A expansão das exportações em volume é significativa, sendo que o país já superou o Brasil, que até o ano de 2000 era o terceiro mais exportador.

Atualmente, o desempenho exportador do setor mostra três grupos de países. A Itália é líder, seguida de perto pela Espanha. No segundo bloco, com volume menor têm-se a Turquia, China e o Brasil, e num terceiro patamar de volume exportador, Indonésia, México e Malásia. Quanto à importação, os EUA, Alemanha e França são os principais compradores no mercado internacional.

O maior grau de maturidade das indústrias da Europa Ocidental em relação ao resto do mundo, fica comprovado com o desempenho exportador da Itália e Espanha, frente aos demais países produtores.

A seguir é feito detalhamento da situação atual de produção, consumo, importação e exportação no segmento de cerâmica de revestimento.

\subsubsection{Mercado internacional}

\subsubsection{Produção}

A produção mundial de cerâmica de revestimento totalizou no ano de 2001, segundo dados da ASCER, o montante de 5.773,4 milhões de $\mathrm{m}^{2}$. A taxa média de crescimento geométrico no período de 90/2001 foi de 10,5\% ao ano. Os picos de crescimento ocorreram nos anos de 1994 e 1995 (Figuras 7 e 8). 
Os principais produtores mundiais são a China (29\%), Itália (11\%), Espanha (11\%), Brasil (8,\%), Indonésia (4\%) e Turquia(2,6\%) (Figuras 9 e 10).

Na década de 90 observou-se que a produção nos países em desenvolvimento cresceu mais que nos países desenvolvidos. A Itália tinha 23\% do mercado em 1990 contra os atuais 11\% (2001).A China foi o país que mais cresceu (700\%) (Figuras 11 e 12).

A Itália e a Espanha, líderes em exportações, competem por design e marca. A imitação ainda é instrumento muito utilizado nesses países, sendo que as empresas líderes lançam novos produtos e tendências que são copiados pelas demais empresas. Existem algumas diferenças nas estratégias competitivas de ambos os países.

A Itália tem indústria cerâmica antiga, com forte competência em design, e indústria de máquinas e equipamentos com liderança mundial. A produção na sua maioria é via úmida e utilizam massa branca, importada, principalmente da Turquia. Como o país é líder na produção de equipamentos para a indústria cerâmica, as inovações tecnológicas foram obtidas por meio de parcerias com esses fornecedores. O preço médio da cerâmica italiana é cerca de US\$ $8 / \mathrm{m}^{2}$ (MEYER-STAMER et al., 2000).

$\mathrm{Na}$ Espanha existe forte apoio do governo, principalmente na manutenção de instituições de pesquisa e treinamento. A produção é via úmida. A matéria-prima utilizada é a chamada argila vermelha, desenvolvida localmente. O país é líder mundial na produção de insumos sintéticos, sendo que todos os grandes colorifícios têm plantas localizadas na região de Castellón. Dessa forma, as parcerias são mais intensas com os fornecedores de matérias-primas sintéticas. O preço médio da cerâmica espanhola é de US\$ 5/m² (MEYER-STAMER et al., 2000).

Os mercados-alvos também são diferentes. A Itália produz mais pisos para construções não residenciais, enquanto a Espanha produz pisos e revestimentos para usos tradicionais. Regionalmente, a Espanha está mais presente nos mercados em desenvolvimento, como a América do Sul, América Central e Extremo Oriente (GORINI \& CORRÊA, 1999).

Nos dois países existe expressiva oferta de serviços de design na forma de estúdios e centros de pesquisa e treinamento específicos para o setor. Na Itália existe expressiva oferta de pequenas indústrias artesanais que desenvolvem produtos de grande valor agregado. 


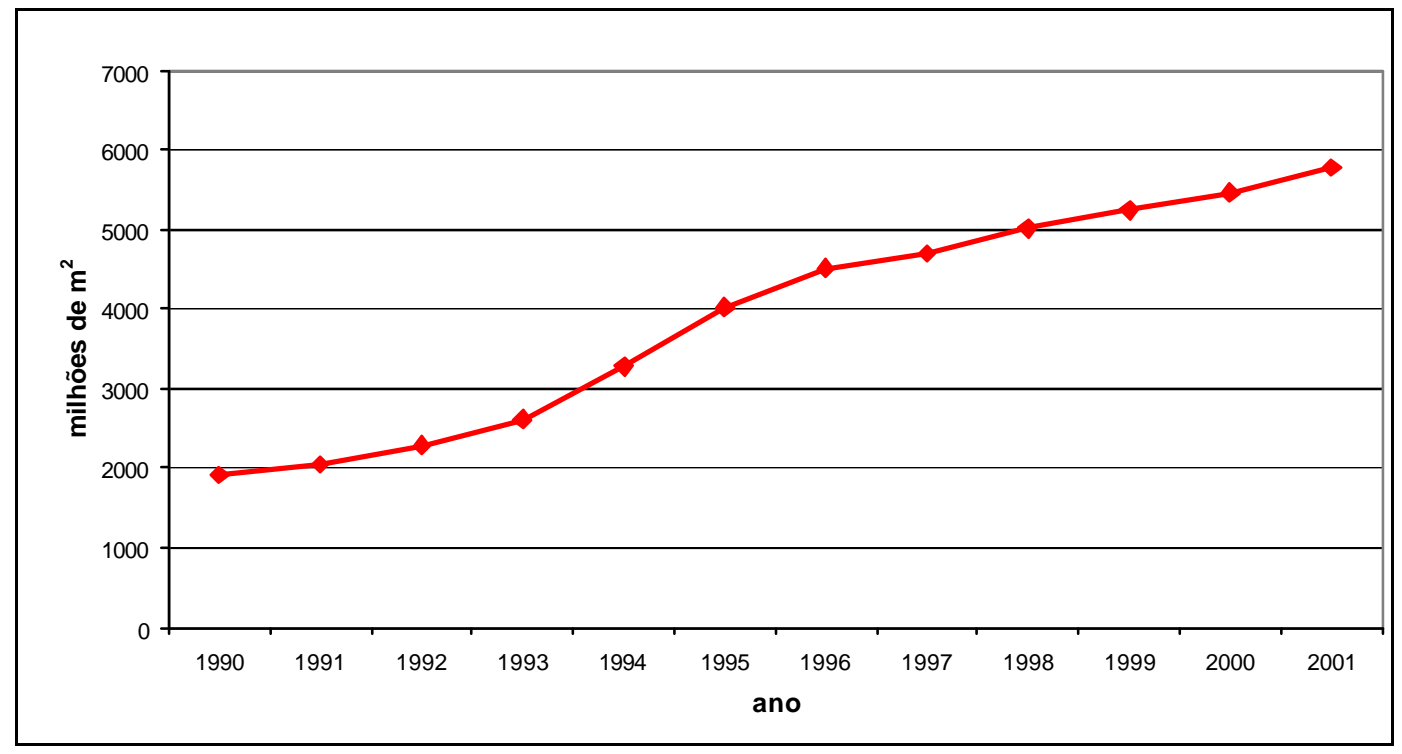

Figura 7 - Evolução da produção mundial de cerâmica de revestimento. Fonte: ASCER, 2003.

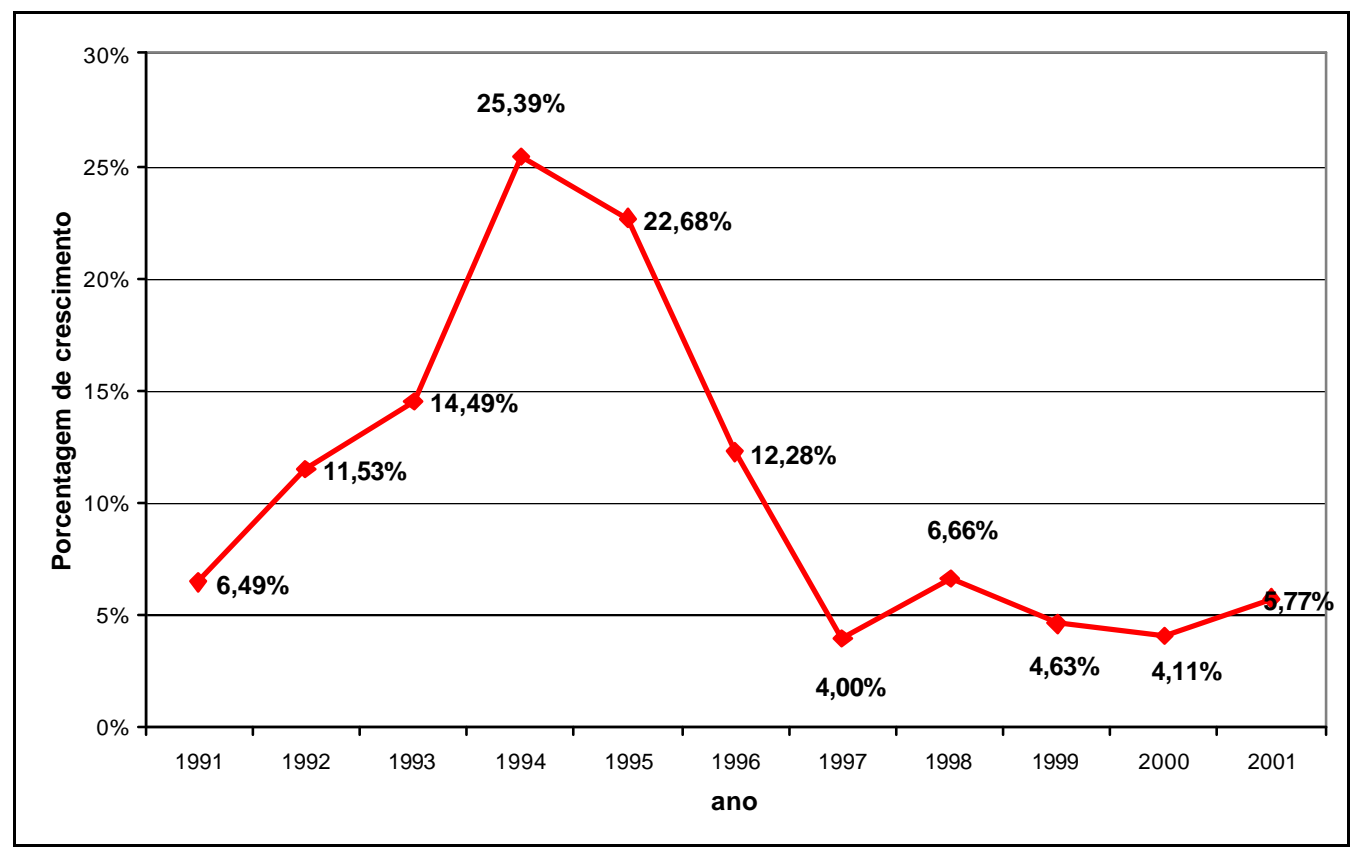

Figura 8 - Taxas geométricas de crescimento da produção mundial de cerâmica de re vestimento. 


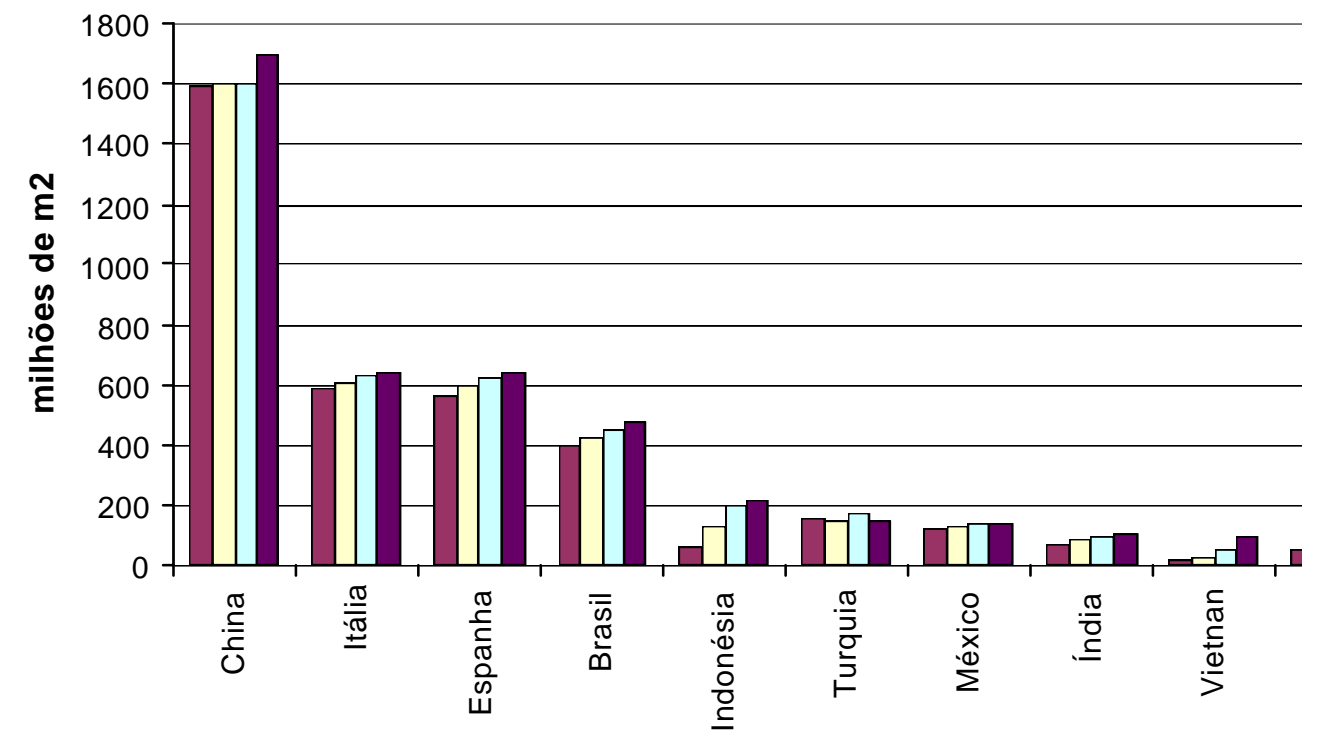

Figura 9 - Evolução da produção mundial de cerâmica de revestimento por país.

Fonte: World Ceramic Review, apud Sezzi, 2002.

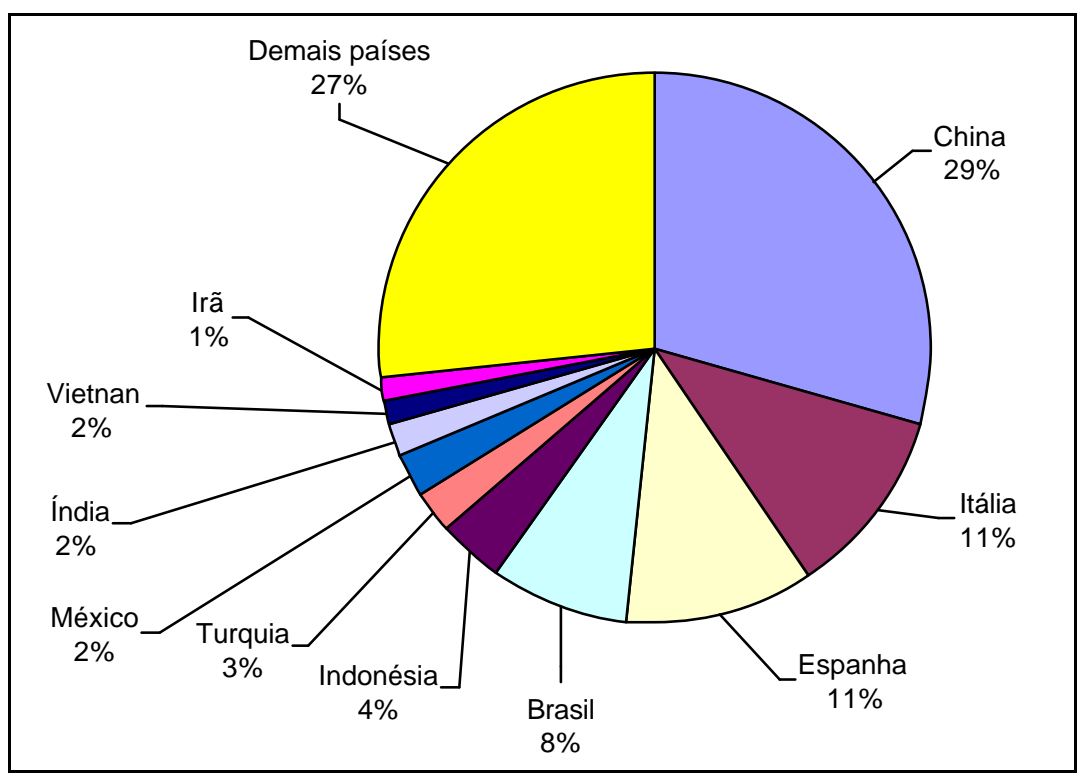

Figura 10 - Participação dos países na produção mundial de cerâmica de revestimento.

Fonte: World Ceramic Review, apud SEZZI, 2002; ASCER, 2003. 


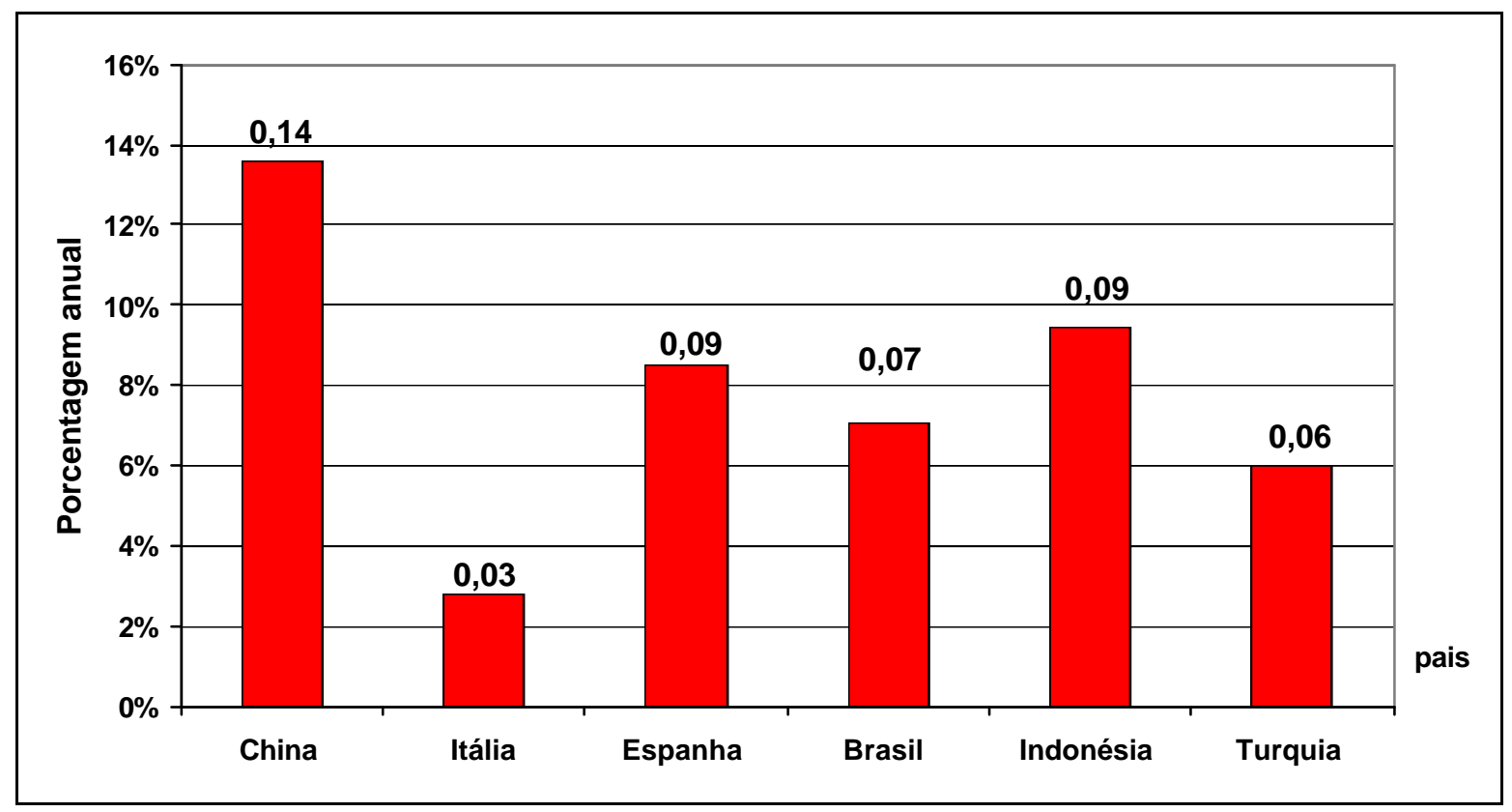

Figura 11 - Taxas geométricas anuais de crescimento da produção (96/2001). Fonte: World Ceramic Review.

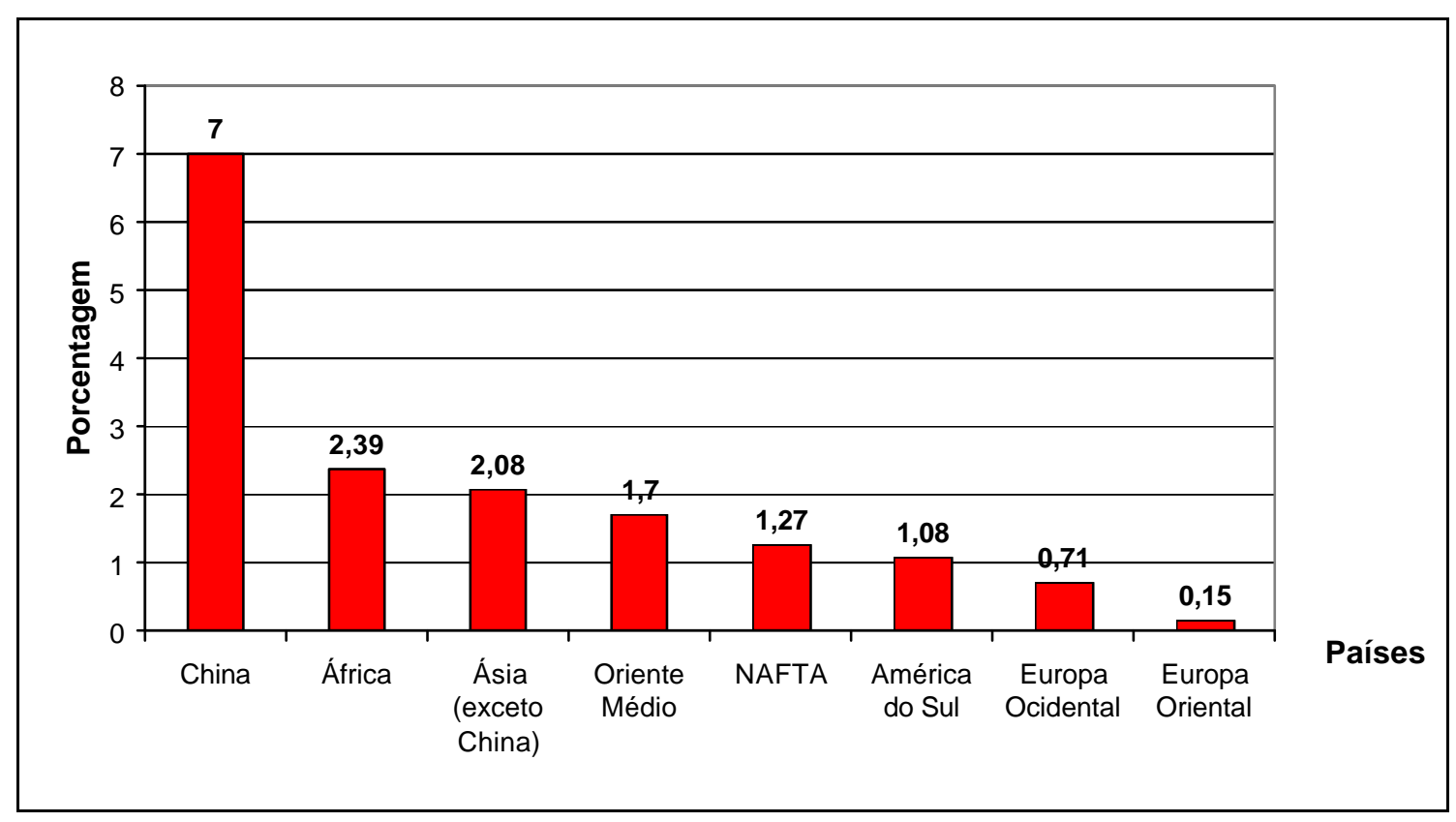

Figura 12 - Taxa de evolução da produção de cerâmica na década de 90.

Fonte: World Ceramic Review, apud GAMBULI, 2001. 


\subsubsection{Consumo}

O consumo no setor de cerâmica de revestimento está condicionado ao crescimento da construção civil e ao comportamento da renda agregada. Além disso, é influenciado pela capacidade da indústria de enfrentar a competição de produtos substitutos como as pedras naturais, revestimentos têxteis e de papel, vinil, madeiras e argamassas (FERRAZ, 2002).

O consumo mundial de cerâmica de revestimento, no ano de 2001 foi de 4.447 milhões de $\mathrm{m}^{2}$, havendo crescido à taxa geométrica de $6,2 \%$ ao ano no período 1998/2001 (). Na década de 90 (de 1990 a 2000) houve crescimento de 132\%, passando de 1850 milhões de $\mathrm{m}^{2}$ em 1990 para 4063 em 2000 (SEZZI, 2002), resultando em taxa de crescimento de 8,30\% ao ano, no período 1990/2001. De acordo com SEZZI, "o aumento da produção mundial foi a resposta natural ao forte aumento do consumo". As regiões que mais cresceram foram as de países subdesenvolvidos, onde o crescimento de renda faz crescer a demanda habitacional, e os EUA.

Os maiores consumidores são China (36\% do consumo mundial), Brasil (9\%), Espanha (7\%), EUA (5\%), Itália (4\%), Indonésia (4\%), Alemanha (4\%). As maiores taxas de crescimento no período 98/2001 foram Indonésia (67,1\%), México (19,3\%), Índia (17,3\%), Espanha (7,7\%), EUA (5,9\%) e Brasil (5,1\%), (Figuras 13 e 14).

A Assopiastrelle, associação italiana de produtores de revestimentos cerâmicos publicou previsões sobre a tendência de crescimento da demanda mundial para o biênio 2002/03, estabelecendo três blocos distintos: área de estagnação, área de crescimento médio e área de crescimento rápido (FERRAZ, 2002).

A área de estagnação inclui a União Européia, em que as taxas de crescimento da demanda para os anos 2002 e 2003 (respectivamente 0,2\% e 1,9\%) estariam comandadas pela construção não residencial. Os mercados de rápido crescimento, localizados na Europa Central e Oriental, teriam taxas de crescimento conjunto de 7,6\% em 2002 e de 11,3\% em 2003, baseando-se na construção habitacional. O terceiro bloco, formado pelos demais países deveriam apresentar crescimento médio de $5,1 \%$ em 2002 e de $8,1 \%$ em 2003. 
O indicador de consumo per capita mostra que os países em desenvolvimento, como Brasil, Turquia e México, ainda apresentam possibilidade de crescimento, comparando-se com taxas da Espanha e Itália (Figuras 15, 16 e 17). Os EUA, apesar de serem país desenvolvido, também apresentam possibilidade de crescimento. $\mathrm{O}$ consumo per capita mundial apresenta comportamento crescente e existe previsão de que continue crescendo até o ano 2010 (Figura 18).

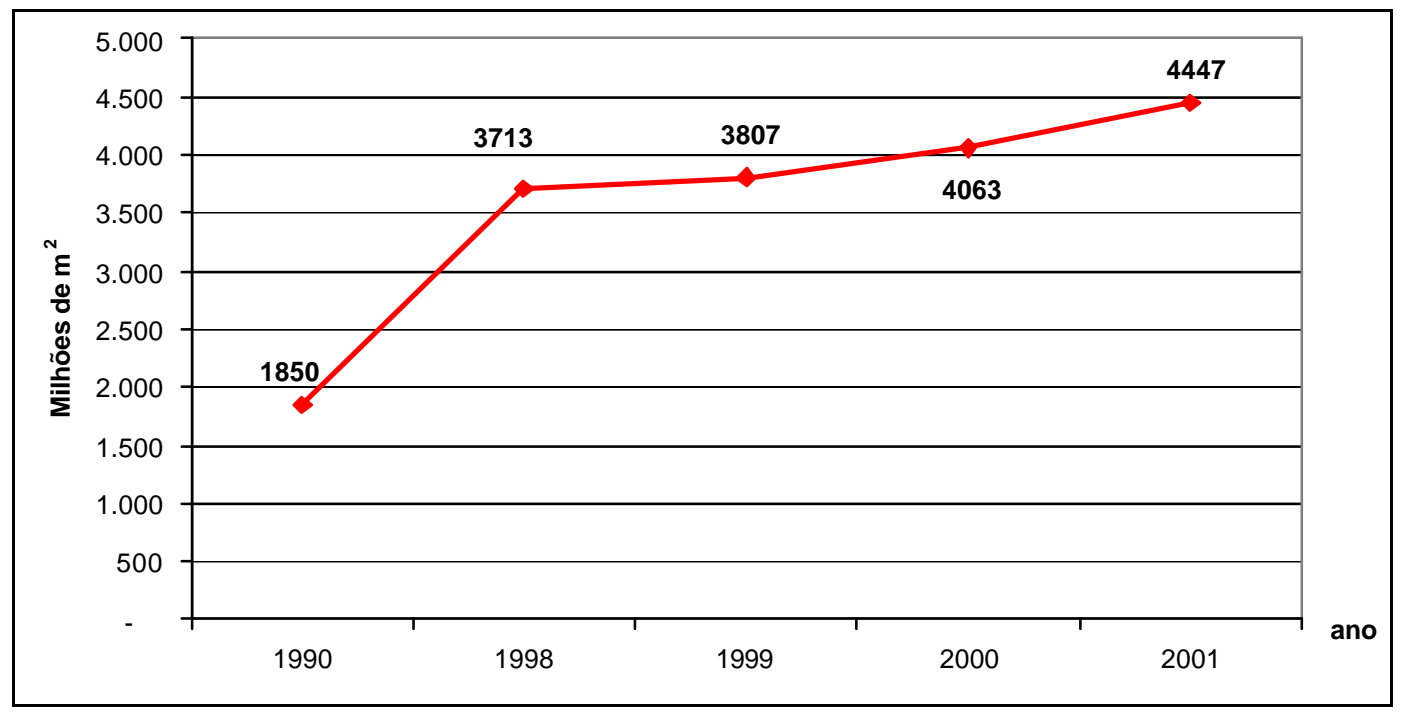

Figura 13 - Evolução do consumo mundial de cerâmica de revestimento.

Fonte: Ceramic World Review, apud SEZZI, 2002. 


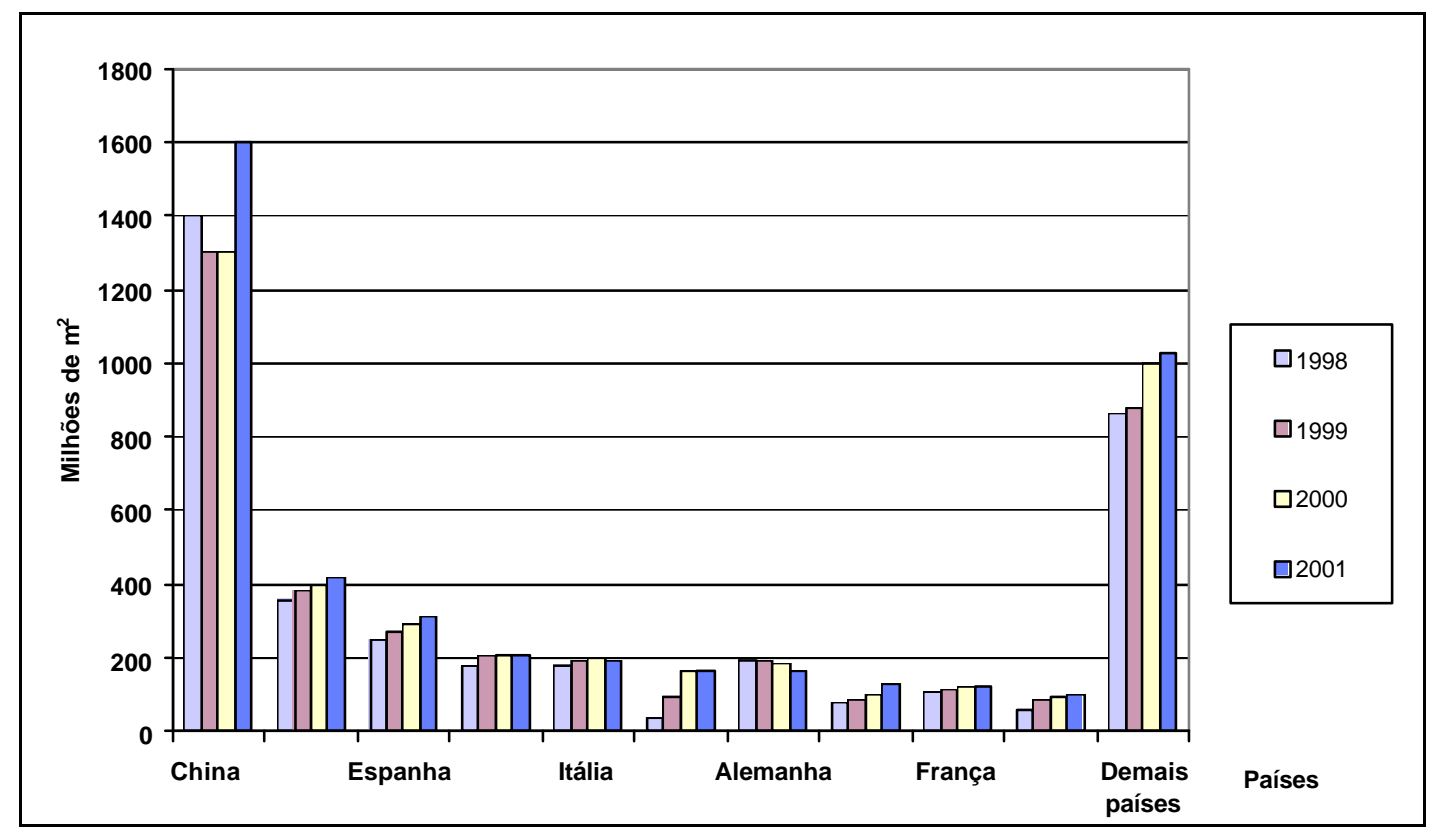

Figura 14 - Evolução do consumo mundial por país.

Fonte: Ceramic World Review, 2002, apud SEZZI, 2002.

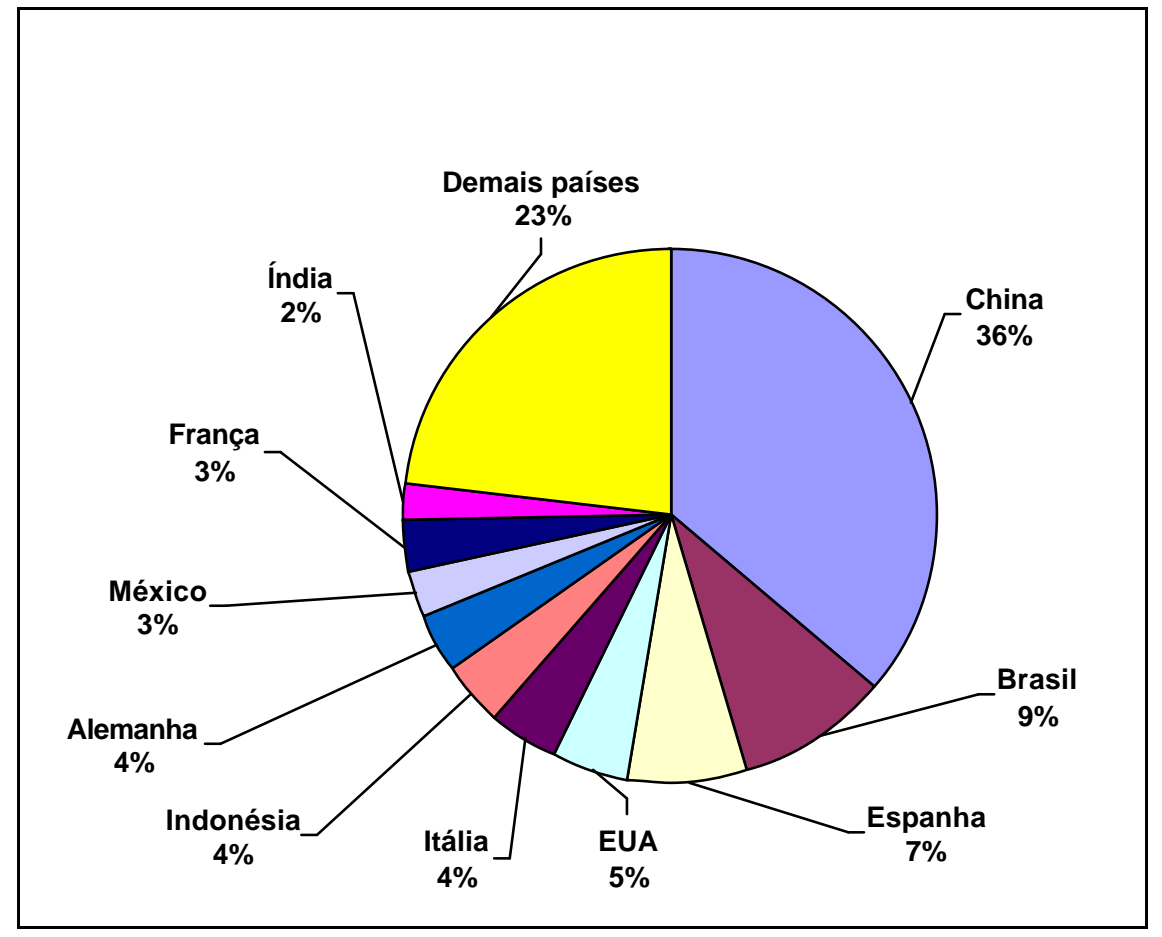

Figura 15 - Participação no consumo mundial (2001).

Fonte: World Ceramic Review, apud SEZZI, 2002. 


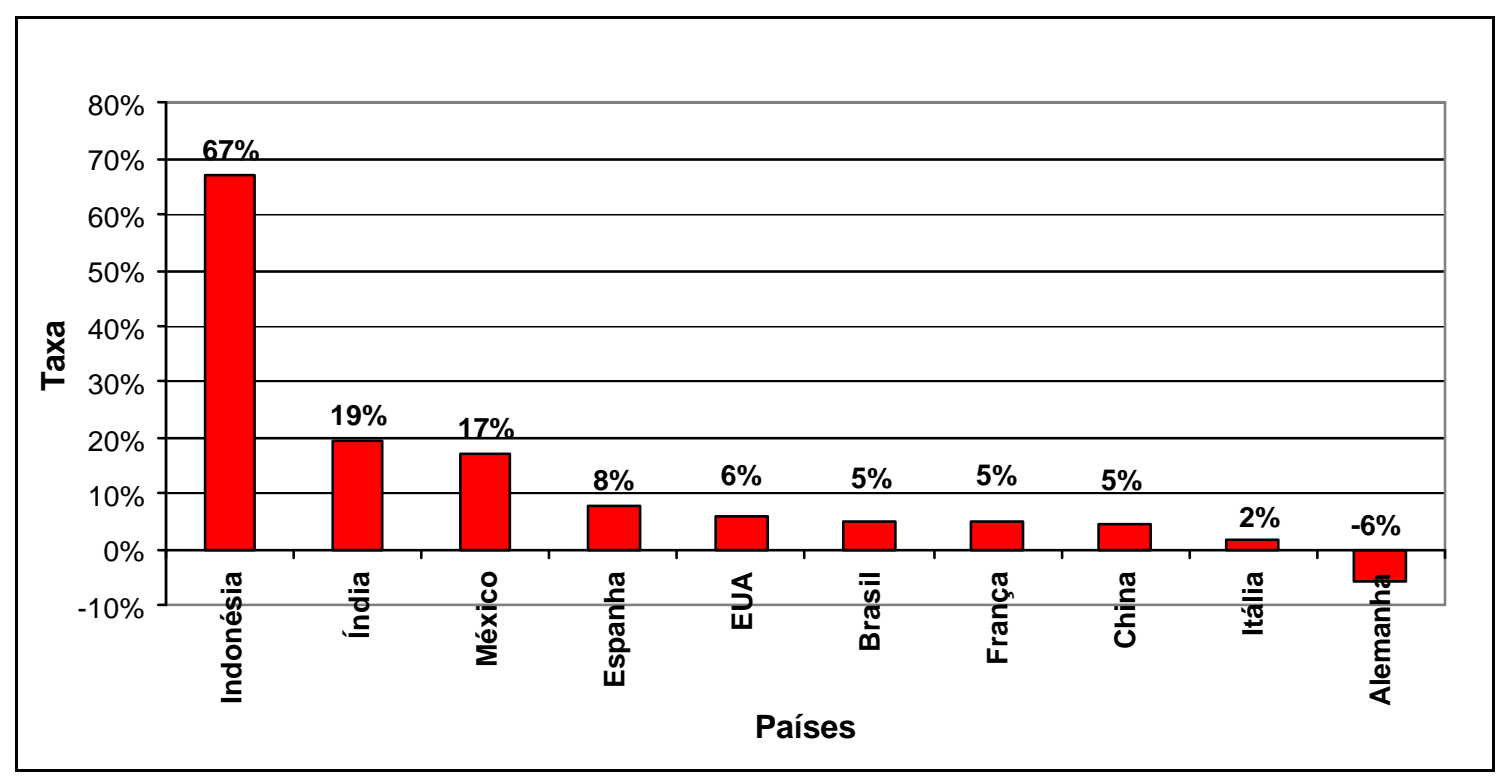

Figura 16 - Taxas geométricas de crescimento do consumo (98/2001).

Fonte: Baseado em W orld Ceramic Review, apud SEZZI, 2002, GAMBINI, 2001.

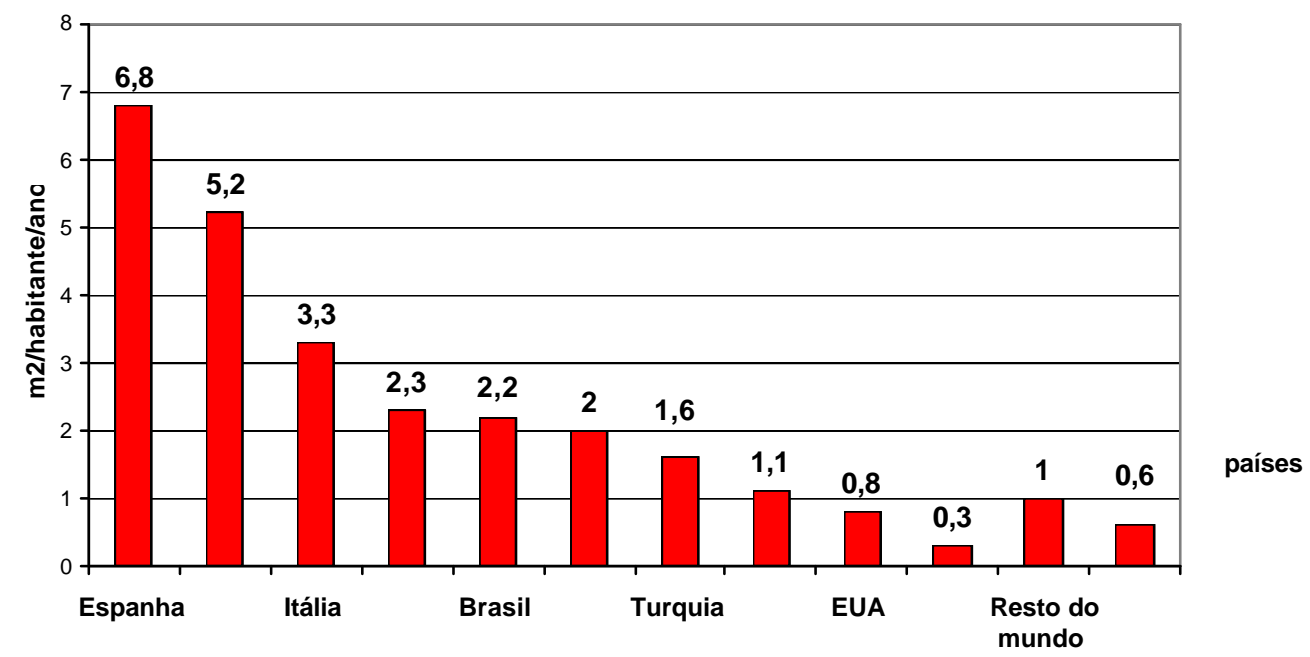

Figura 17 - Consumo per capita de cerâmica de revestimento (1999).

Fonte: ASCER, apud FERRAZ, 2002. 


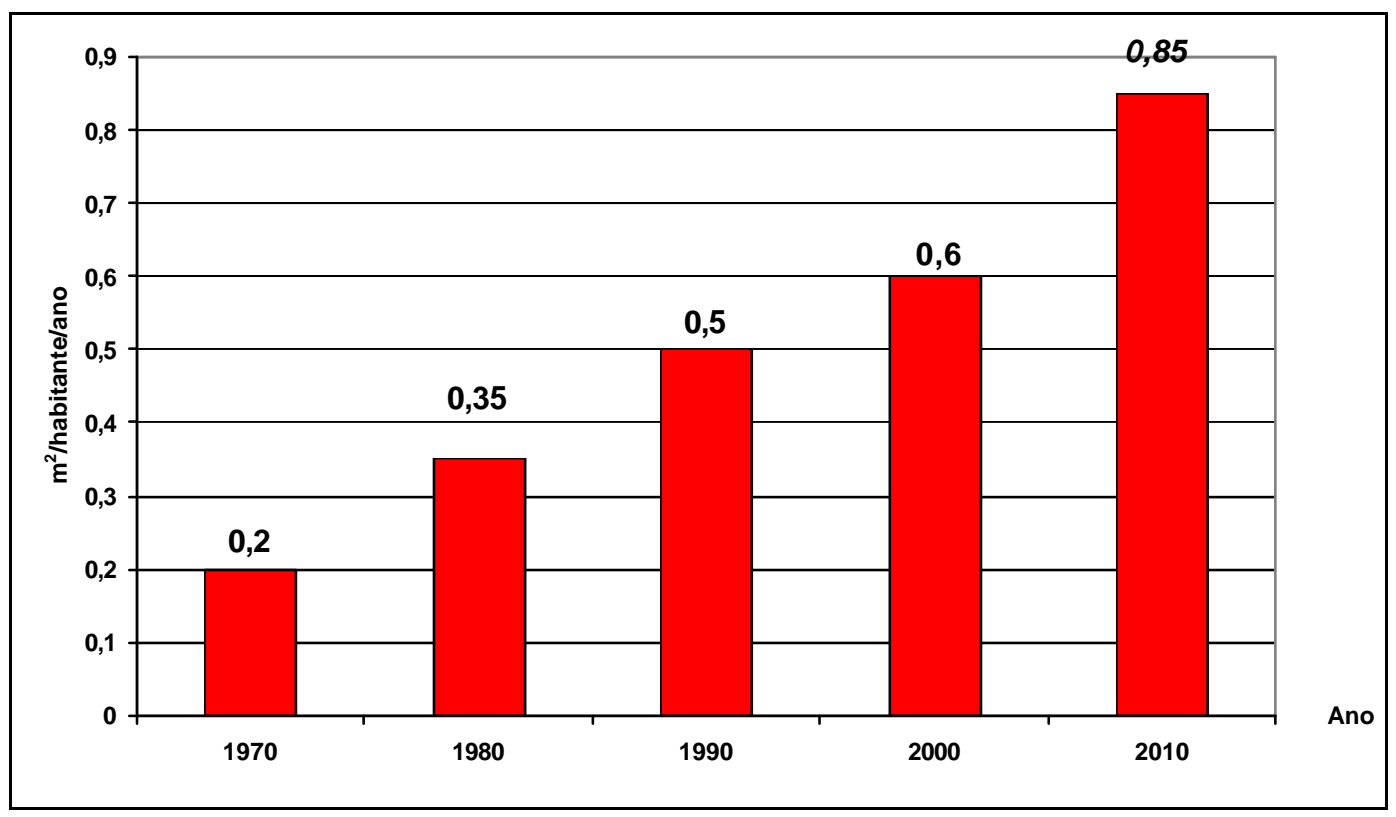

Figura 18 - Evolução do consumo médio per capita no mundo.

Fonte: Mundo Cerâmico, 2003.

\subsubsection{Fluxos internacionais}

O fluxo mundial de cerâmica de revestimento representa aproximadamente $25 \%$ da produção mundial, tendo alcançado o volume de 1.215 milhões de $\mathrm{m}^{2}$ no ano de 2001 (Figura 19). A taxa geométrica média de crescimento no período 98/2001 foi de 6,4\% ao ano De acordo com Gambuli (2001) os fluxos caem para aproximadamente $8 \%$ se não forem considerados os fluxos nas regiões economicamente integradas ou vizinhas.

Os principais países exportadores são a Itália (36\%), Espanha (27\%), Turquia (5\%), China (4\%) e Brasil (4\%) (Figura 19).

Observa-se que Itália e Espanha são responsáveis por 62,4\% das exportações mundiais e 16,0\% do consumo mundial e as exportações dos 10 maiores países exportadores representam 21,6\% do consumo mundial (SEZZI, 2002). 
A importância da exportação para os líderes é bastante significativa. Em 2001, a Itália exportou $69 \%$ de sua produção e a Espanha 53\%. Outro país que a exportação tem importância é na Turquia, com $38 \%$ da produção no mesmo ano. A China e o Brasil exportam pequenas parcelas de sua produção: $3 \%$ e $10 \%$, respectivamente. A exportação da China, apesar de pouco significativa em termos de produção apresenta grandes taxas de crescimento (40,8\% ao ano no período 98/2001), ultrapassando o volume brasileiro em 2001.

Os principais importadores mundiais são EUA (13\%), Alemanha (10\%), França $9 \%$ ) e Reino Unido (4\%), (Figura 25).

A Alemanha era o maior importador até 1999, mas vem apresentando volumes decrescentes de importação (Figura 24).

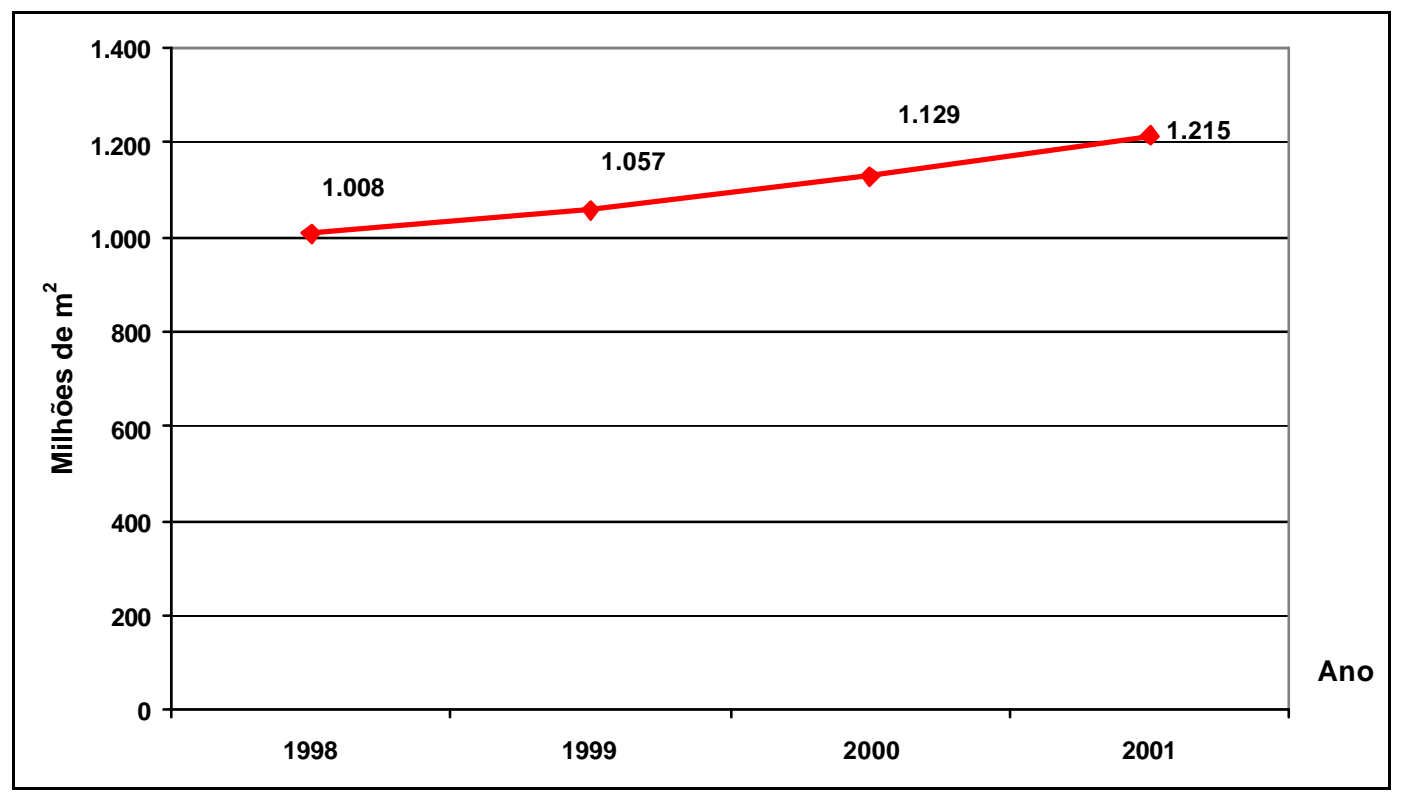

Figura 19 - Evolução das exportações mundiais (98/2001).

Fonte: World Ceramic Review, apud SEZZI, 2002. 


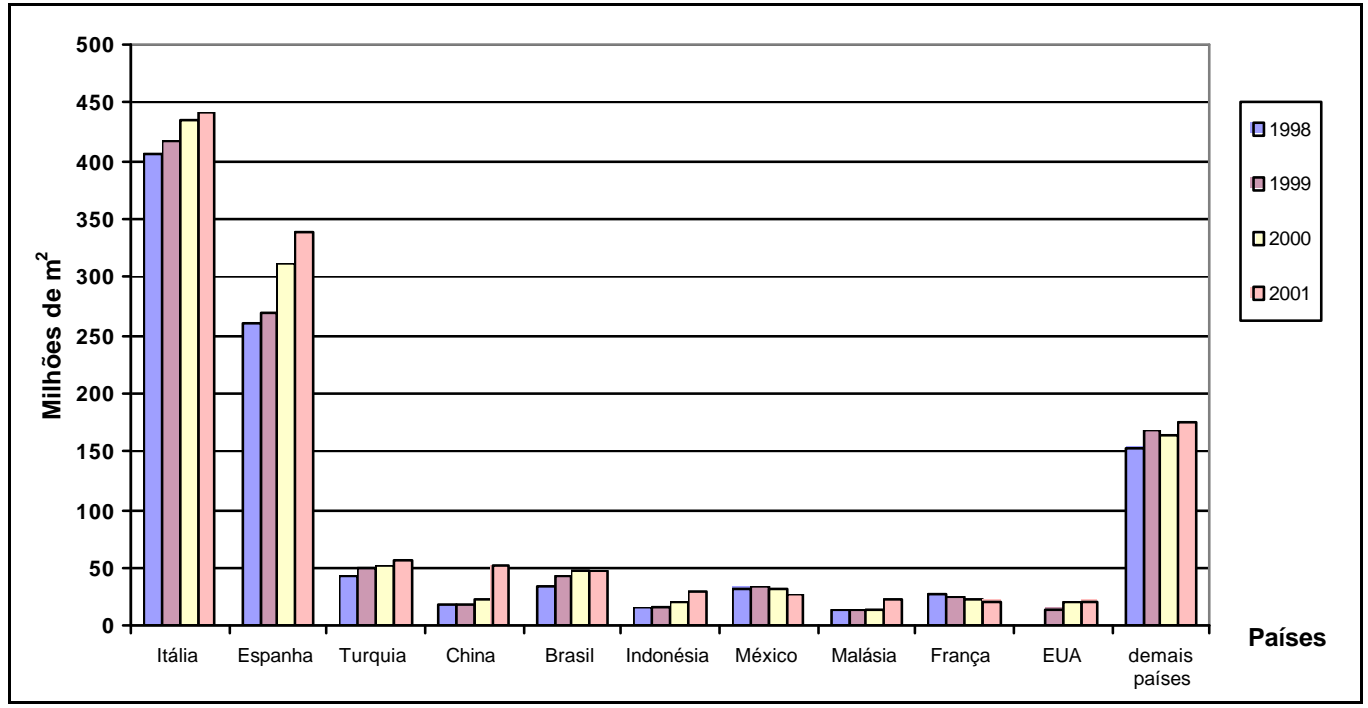

Figura 20 - Principais países exportadores de cerâmica de revestimento.

Fonte: World Ceramic Review, apud SEZZI, 2002.

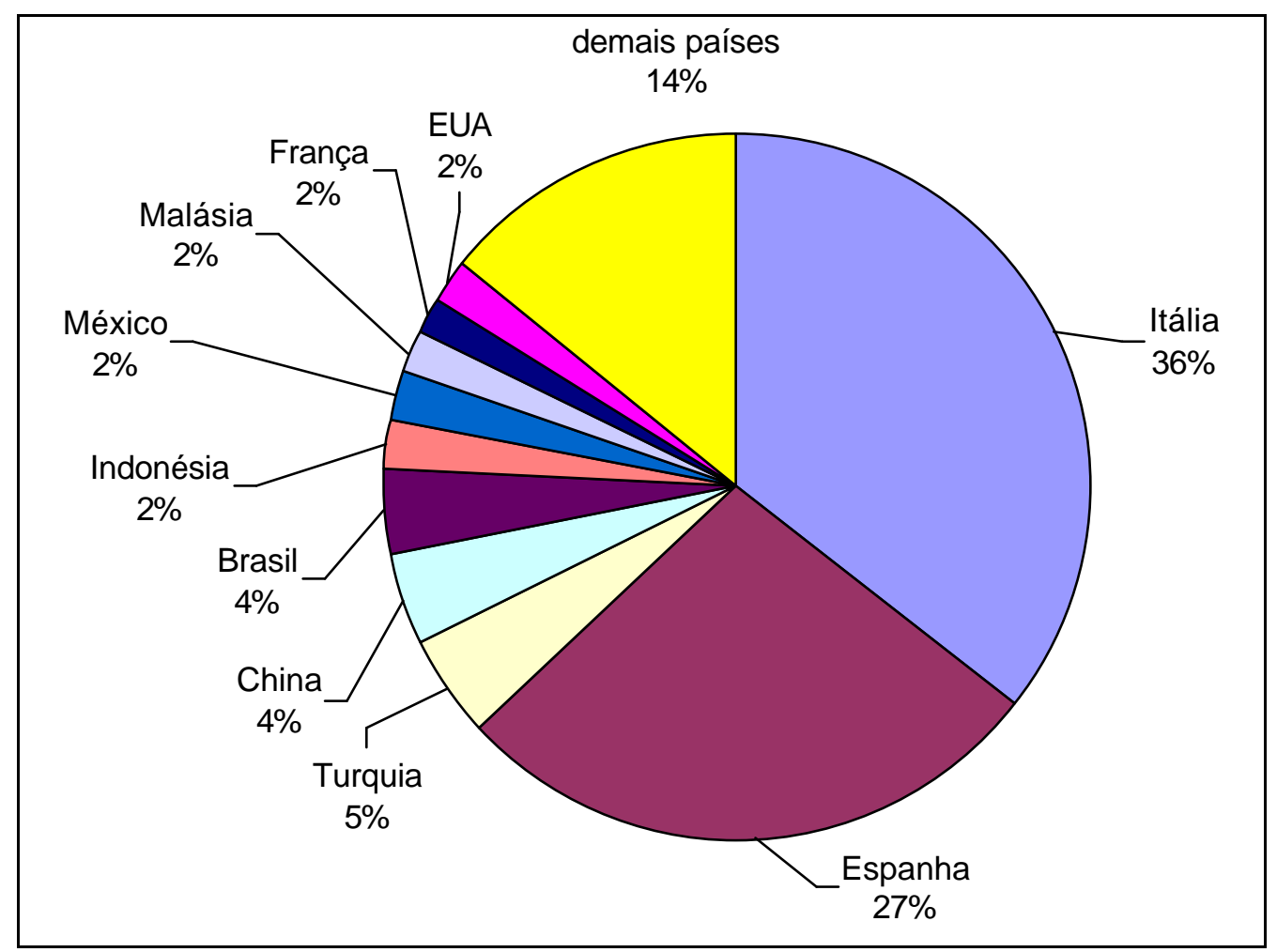

Figura 21 - Participação dos países na exportação em 2001.

Fonte: Ceramic World Review, apud SEZZI, 2002. 


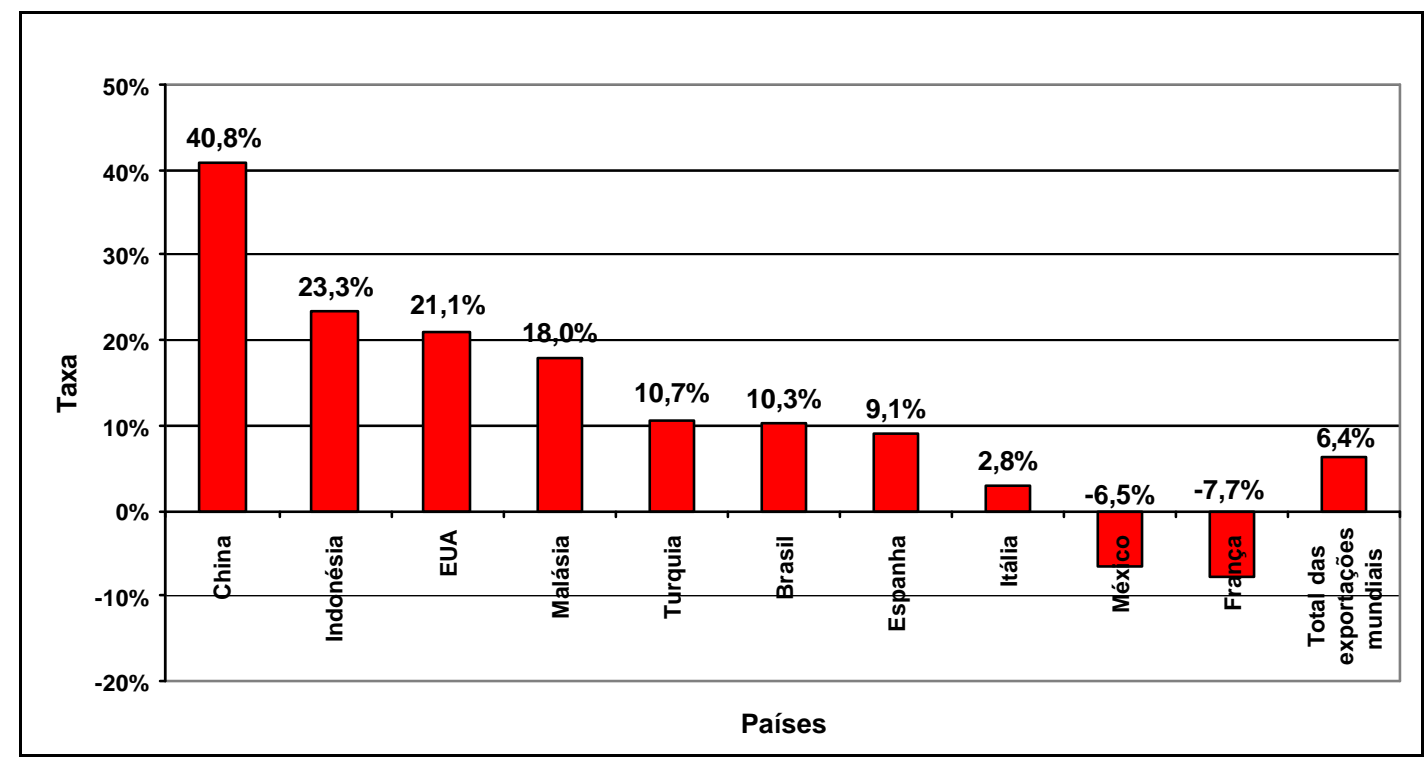

Figura 22 - Taxa geométrica de crescimento das exportações (98/2001).

Fonte: Ceramic World Review, apud SEZZI, 2002.

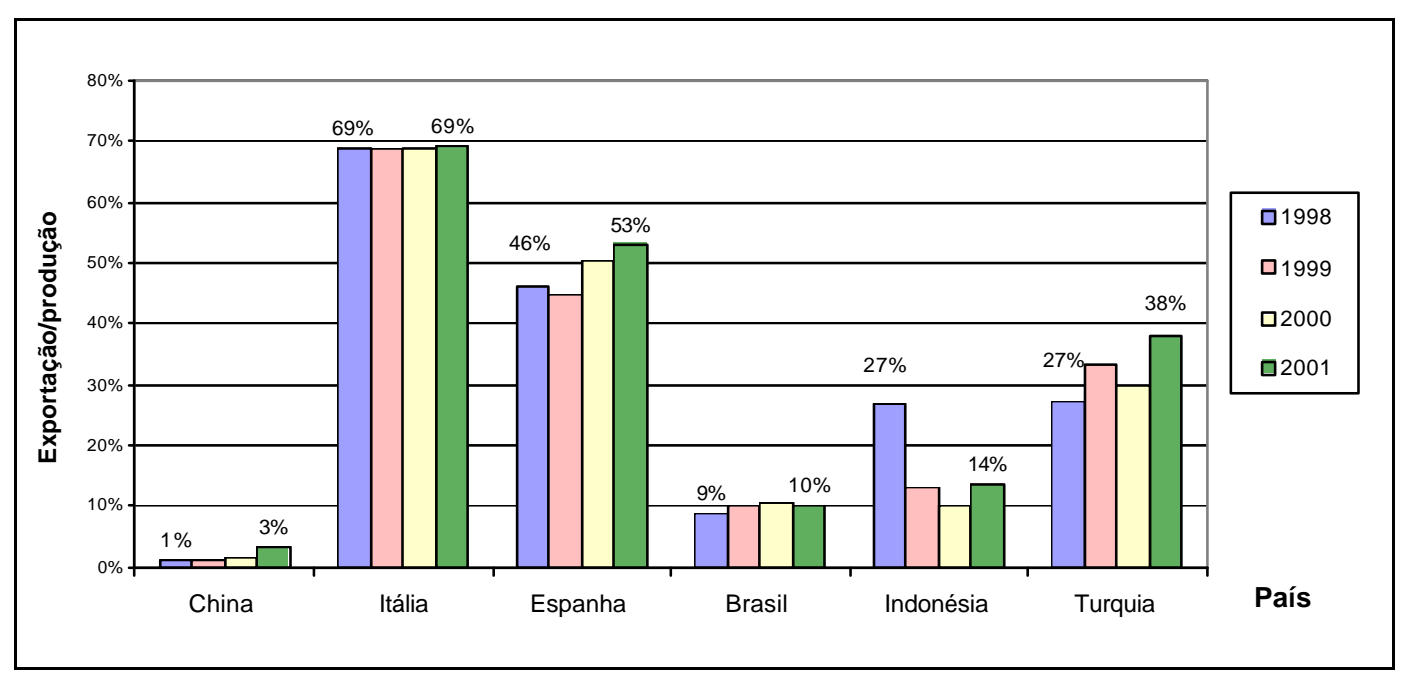

Figura 23 - Participação das exportações na produção dos principais países produtores.

Baseado em World Ceramic Review, apud SEZZI, 2002. 


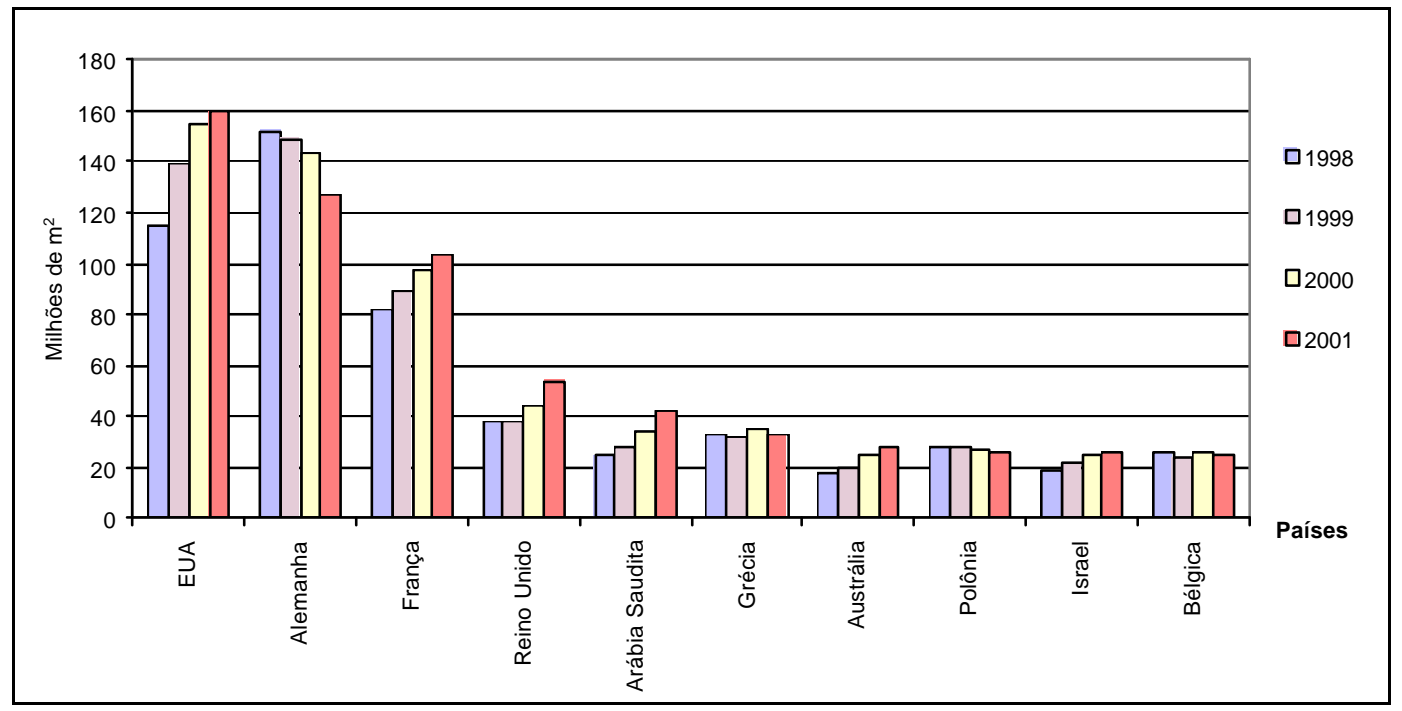

Figura 24 - Principais importadores de cerâmica de revestimento.

Fonte: Ceramic World Review, apud SEZZI, 2002.

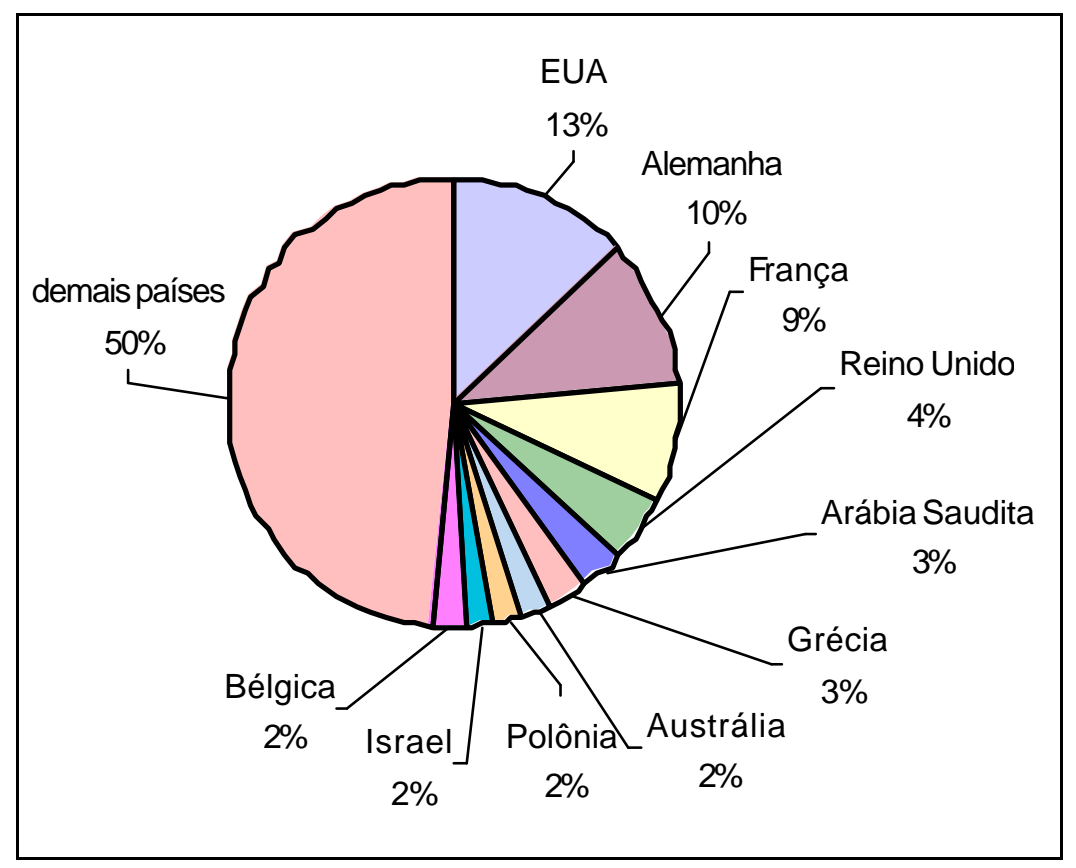

Figura 25 - Participação dos principais importadores no total de importações mundiais.

Fonte: Ceramic World Review, apud SEZZI, 2002. 


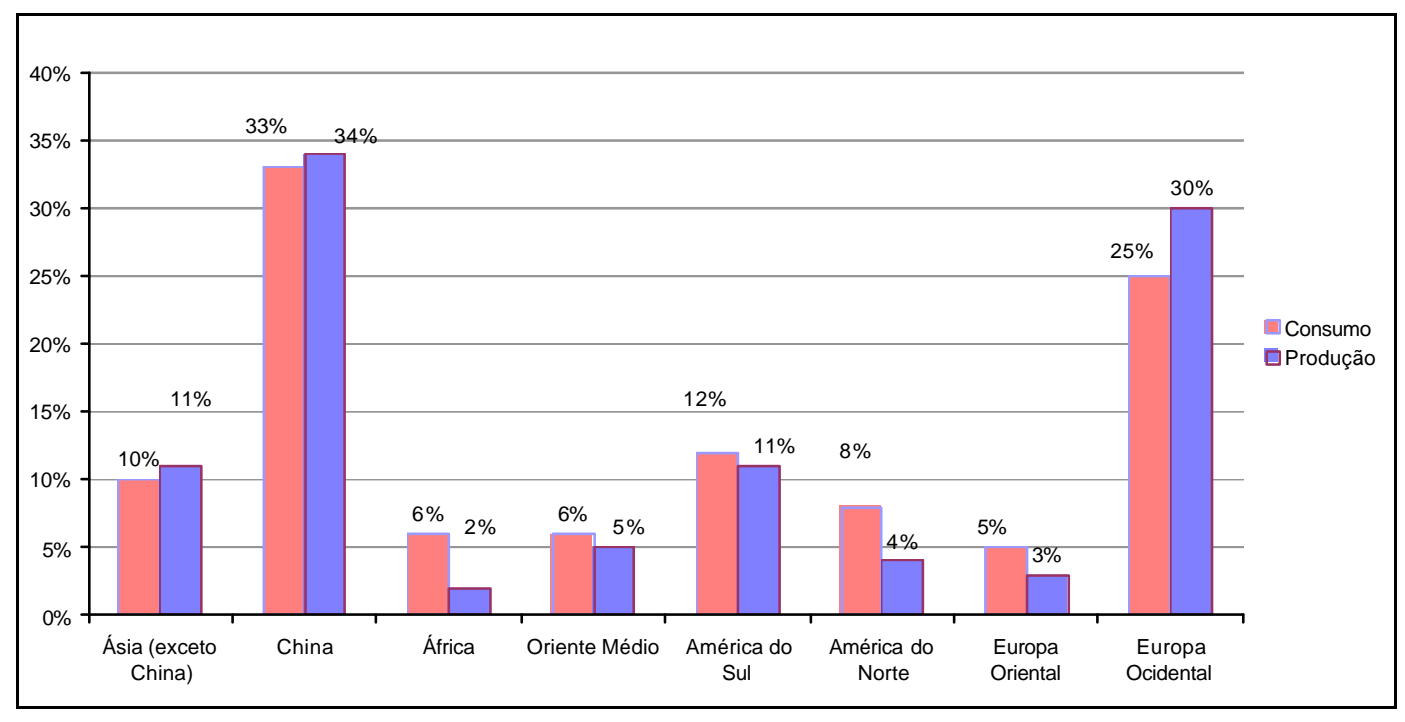

Figura 26 - Cotas de consumo e produção de cada região sobre a produção mundial em 2000.

Baseado em Ceramic World Review, apud GAMBULI, 2001.

\subsubsection{Mercado Brasileiro}

O Brasil é o quarto produtor mundial, responsável pela produção de 473,4 milhões de $\mathrm{m}^{2}$ em 2001 (Figura 27). A taxa de crescimento média foi de $9,6 \%$ ao ano no período de 90/2001 (Figura 28). Existem 131 empresas distribuídas pelo território nacional que geram 23.000 empregos diretos e 160.000 indiretos (ANFACER, 2001, apud NOGUEIRA et al., 2001).

A maior parte da produção brasileira se concentra na região sudeste (58\%) e sul (33\%) (Figura 29). A região de Criciúma, em Santa Catarina, que tem reconhecimento como pólo internacional, concentra as maiores empresas brasileiras. Nessa região, as empresas produzem com tecnologia via úmida e competem por design e marca, em faixas de preços mais altas. Em São Paulo, a produção está distribuída em dois pólos: Mogi Guaçú e Santa Gertrudes. A região metropolitana de São Paulo conta com algumas empresas, mas não se configura um APL. As empresas da capital e Mogi produzem via úmida, enquanto em Santa Gertrudes a produção é majoritariamente via seca. 
As exportações brasileiras foram $10 \%$ da produção em 2001 e $15 \%$ em $2002^{1}$. O estado de Santa Catarina é responsável por $64 \%$ do volume exportado, enquanto o estado de São Paulo fica com 17,4\% (Figura 31). O principal mercado para importação dos produtos brasileiros são os EUA, 42,7\% do total exportado. No primeiro semestre de 2002, os outros destinos das exportações brasileiras foram Canadá $(7,7 \%)$, Chile $(5,0 \%)$, Porto Rico $(4,2 \%)$, Paraguai $(4,0 \%)$ e Reino Unido $(2,9 \%)$ (Figura 30). O total exportado para a Argentina, que no ano anterior foi o segundo maior destino de exportações, teve queda bastante significativa.

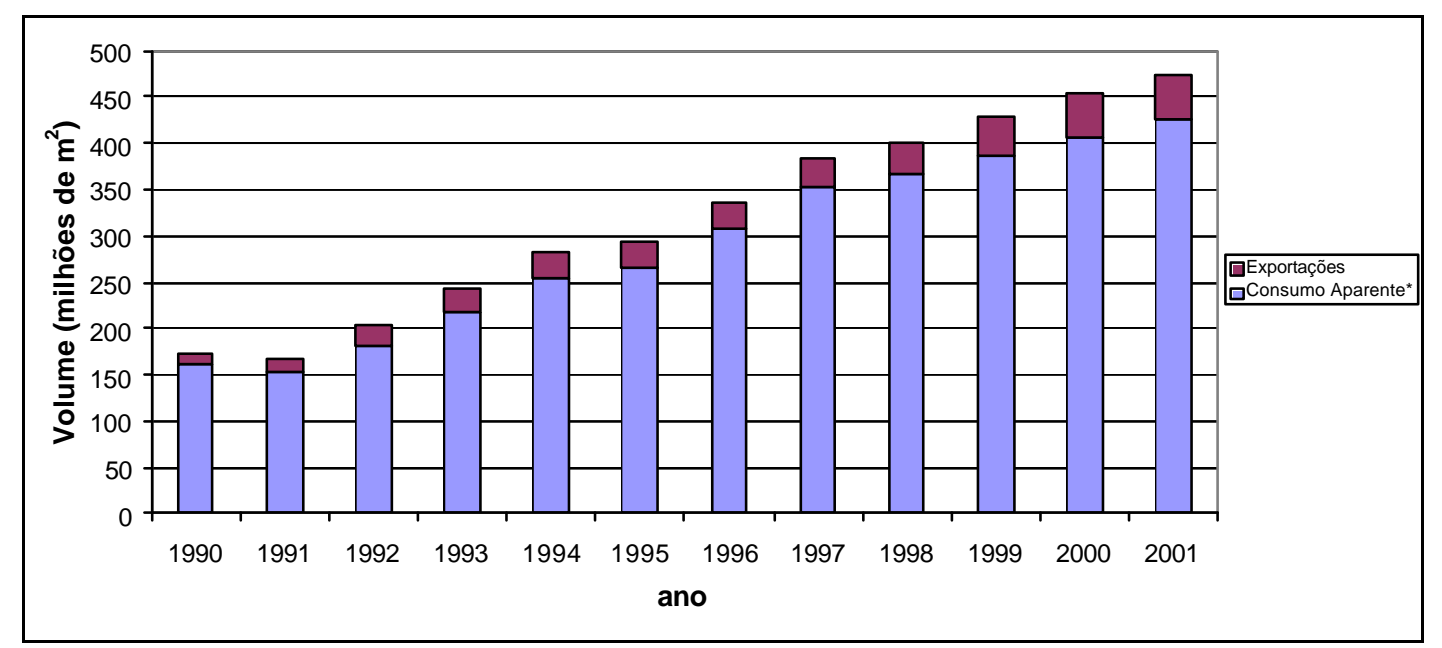

Figura 27 - Evolução da produção brasileira de cerâmica de revestimento.

Fonte: ANFACER, apud FERRAZ, 2002.

${ }^{1}$ A informação sobre exportações em 2002 foi fornecida por José Octavio Paschoal, diretor do CCB. 


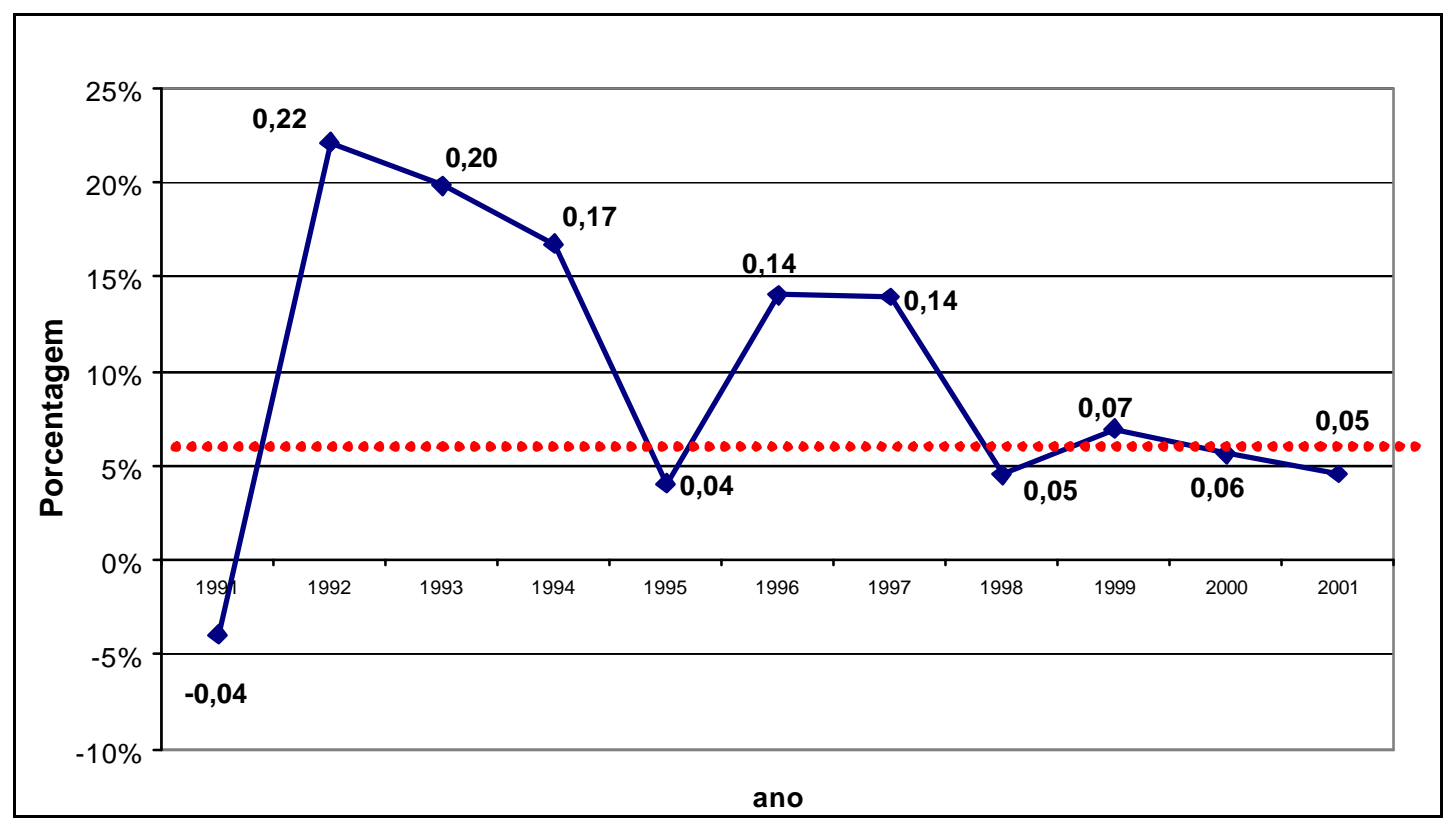

Figura 28 - Taxa geométrica de crescimento da produção.

Fonte: ANFACER, apud FERRAZ, 2002.

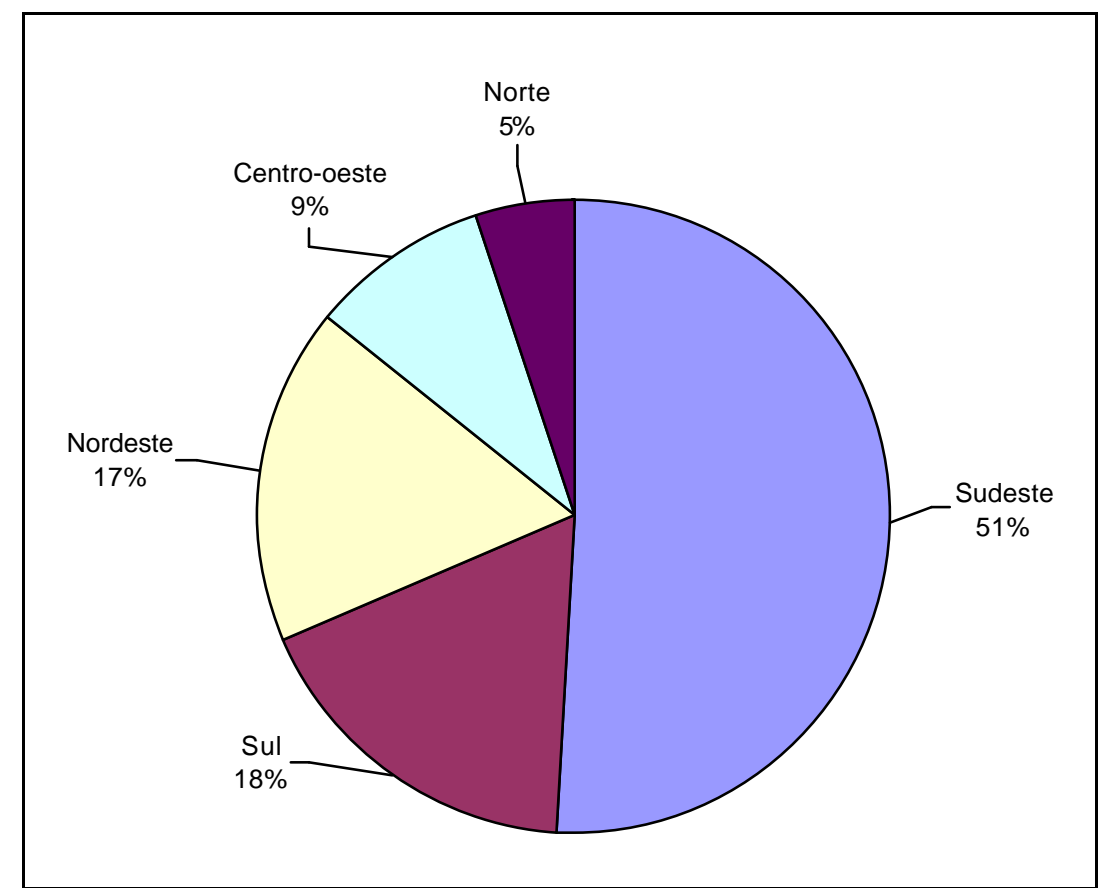

Figura 29 - Distribuição regional da Cerâmica de revestimento no Brasil.

Fonte: ANFACER, 2003. 


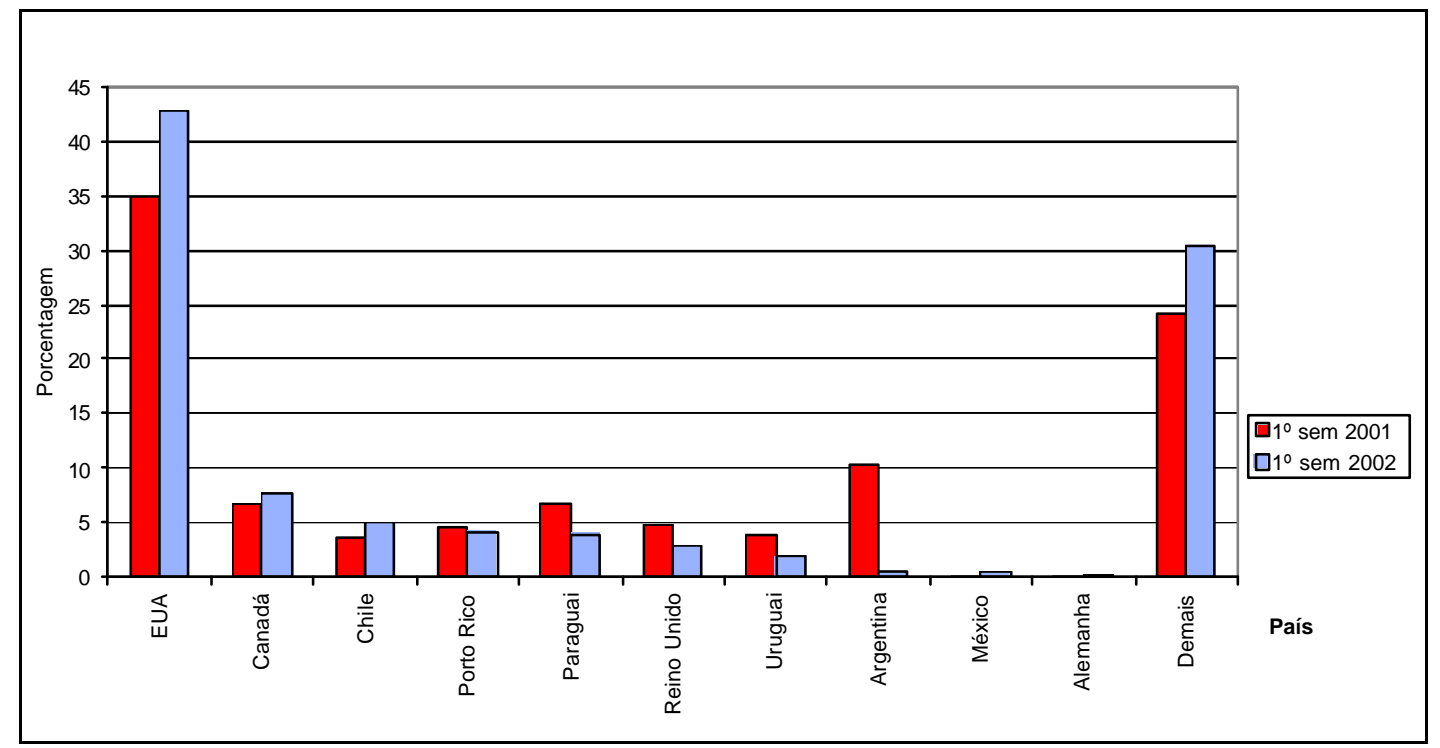

Figura 30 - Destino das exportações brasileiras.

Fonte: FERRAZ, 2002.

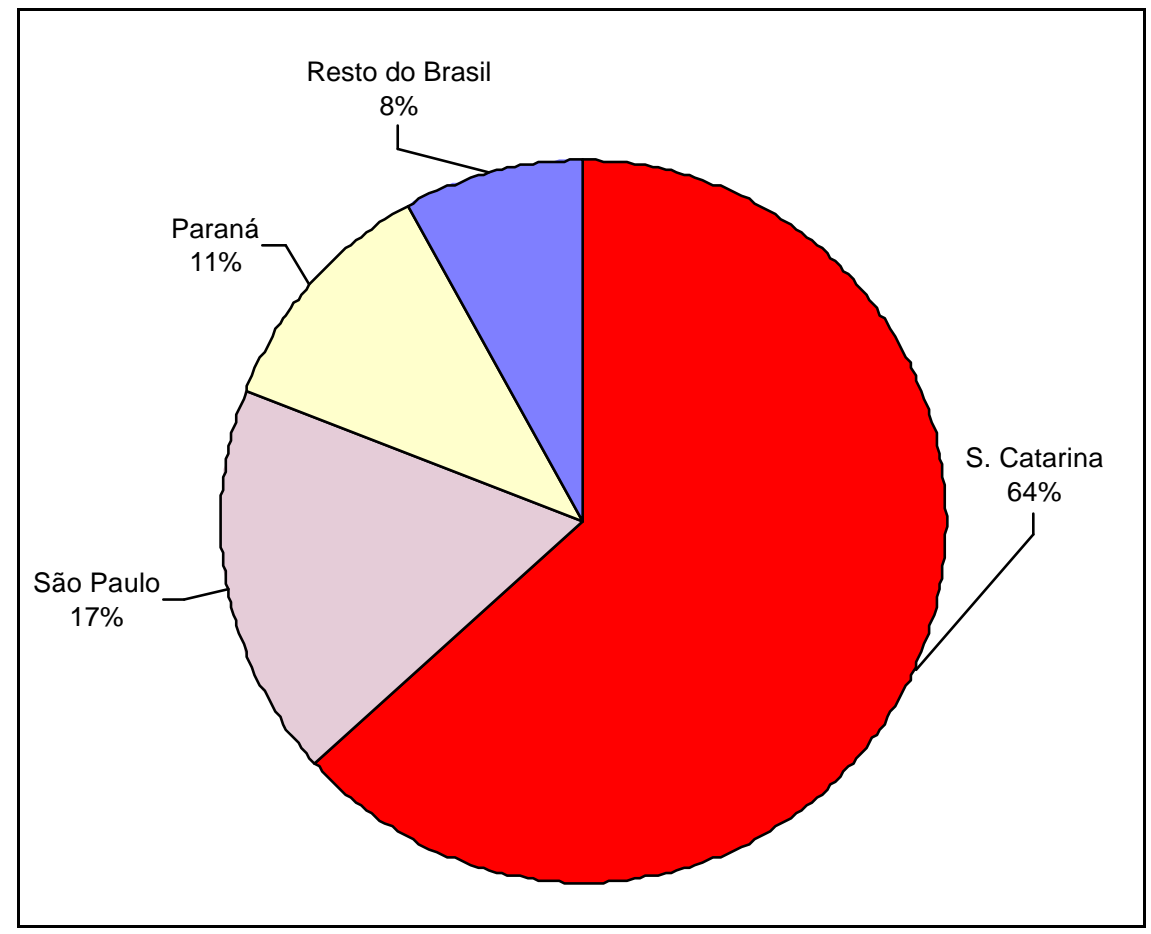

Figura 31 - Origem das exportações brasileiras por região.

Fonte: FERRAZ, 2002. 


\section{O APL DE SANTA GERTRUDES}

\subsection{Caracterização e escala}

Os municípios de Santa Gertrudes, Cordeirópolis, Rio Claro, Limeira, Araras, Piracicaba e Ipeúna abrigam $43^{1}$ empresas produtoras de revestimentos cerâmicos com capacidades produtivas que variam entre $80 \mathrm{mil} \mathrm{m} / \mathrm{mês}$ a $1200 \mathrm{mil} \mathrm{m} / \mathrm{mês}$. Percentualmente, $20 \%$ são grandes empresas (mais de $500 \mathrm{mil} \mathrm{m} \mathrm{m}^{2} / \mathrm{mês}$ ), $40 \%$ são médias (entre 300 e 500 mil m² /mês) e $40 \%$ são pequenas (menos que $300 \mathrm{mil} \mathrm{m}^{2} /$ mês).

A produtividade das empresas varia entre $615 \mathrm{~m}^{2}$ /funcionários $\mathrm{x}$ mês até $6250 \mathrm{~m}^{2}$ /funcionários x mês, com média aproximada de $3 \mathrm{mil} \mathrm{m}^{2}$ /funcionários x mês.

A capacidade produtiva do pólo, atualmente (ano de 2003) está entre 18 a 19 milhões de $\mathrm{m}^{2}$ por mês, o que resulta em aproximadamente 220 milhões de $\mathrm{m}^{2}{ }^{2}$ Existe previsão, baseada em informações de fornecedores de equipamentos, de que serão implantadas novas linhas com capacidade de 5 milhões de $\mathrm{m}^{2}$ por mês até o final do ano de 2003 e início de 2004. Dessa previsão, aproximadamente metade é para substituir antigas linhas e metade será para ampliação da capacidade produtiva. Para o ano de 2004 estima-se produção mensal de aproximadamente 21 milhões de $\mathrm{m}^{2}$, o que significa produção anual de 250 milhões de $\mathrm{m}^{2}$.

Nesta pesquisa foram entrevistadas seis empresas produtoras de cerâmica, com capacidades que variam entre 250 e $500 \mathrm{mil} \mathrm{m}^{2} /$ mês e número de funcionários entre 80 e 234 , com produtividade que varia entre 1.548 e $6.250 \mathrm{~m}^{2} /$ funcionários x mês. A origem do capital de todas as empresas entrevistadas é nacional.

A localização é considerada privilegiada devido ao fácil acesso de rodovias que facilita o escoamento dos produtos $\mathrm{e}$ à proximidade dos grandes centros consumidores (estado de São Paulo).

\footnotetext{
1 Segundo levantamento da Divisão de Geologia do IPT, atualmente operam no arranjo de Santa Gertrudes 36 plantas via seca, três plantas via úmida, duas plantas de peças especiais e duas plantas de placas artesanais.

2 As estimativas e previsões sobre a capacidade produtiva do APL de Santa Gertrudes, nos anos 2003 e 2004, são de autoria de José Francisco Motta, pesquisador da divisão de Geologia do IPT.
} 
O crescimento do APL de Santa Gertrudes foi excepcional nos últimos dez anos, devido à conjunção de condições favoráveis, disponibilidade de matéria-prima, tecnologia e crescimento do mercado consumidor, ditado, principalmente, pela estabilidade monetária do Plano Real. Essas circunstâncias favoráveis geraram empresas que, apesar de apresentarem bom desempenho, têm fragilidades em seus fundamentos administrativos, como marketing, logística, gestão de recursos humanos, desenvolvimento de produtos, relações com fornecedores, entre outros. Essas fragilidades passam a ter consequiência sobre o desempenho, a partir do momento em que se alteram as condições competitivas, a demanda se estabiliza e a disputa pelas vendas passa a comprometer as margens de toda a cadeia produtiva.

\subsection{Origem do APL}

A região de Santa Gertrudes era tradicional pólo produtor de telhas. A produção de cerâmica de revestimento se iniciou com a fabricação de lajotões extrudados, que da mesma forma que a produção de telhas, tem um processo de mistura rudimentar, sem utilização de moinhos.

Desse produto evoluiu-se para a produção de pisos prensados, com moagem via seca. A partir da utilização das argilas locais da formação Corumbataí produziu-se com equipamentos usados e obsoletos, adquiridos junto a empresas de cerâmica de revestimento estabelecidas. A queima era realizada em fornos garrafão, anteriormente utilizados na produção de telhas, com participação intensiva de mãode-obra.

A moagem era feita por moinho de martelos, sem adição de água, processo conhecido como via seca, e a umidificação do pó era feita por gotejamento. A experiência na extração de argilas foi fundamental para a nova indústria. Os lajotões eram pisos de dimensões 30x30 com peso de $30 \mathrm{~kg}$ por $\mathrm{m}^{2}$ e foram produzidos até o ano de 1987.

O processo apresentava muita variação, resultando em defeitos de superfície, baixa resistência mecânica, baixa aderência de esmaltes, gretamento, trincas, expansão por umidade e baixa estabilidade dimensional. O esmalte, geralmente resíduo de outras indústrias, era aplicado por gotejamento, de forma a esconder os furos que ficavam em sua superfície. Algumas variações de colorações escuras (marrons e cinzas) 
disfarçavam defeitos de superfície. Nessa fase não havia nenhuma preocupação com normas e especificações.

A produção se limitava aos formatos $20 \times 30$ e 30x30, resultando em tempos mínimos de set-up, pela pequena quantidade de trocas no processo produtivo.

Esses produtos foram amplamente aceitos pelo mercado de baixa renda, reforçando a vantagem competitiva em custos das empresas locais. Na distribuição, os antigos parceiros da cerâmica estrutural procediam à revenda das placas cerâmicas.

A utilização do processo via úmida não seria possível, pois as argilas locais apresentariam dificuldades de defloculação. $\mathrm{O}$ uso de composição de poucas argilas reduziu a necessidade de investimentos em sistemas de estocagem, dosagem, moagem, atomização e silos. A moagem a úmido também implicaria em custos adicionais com defloculantes, energéticos, manutenção, mão-de-obra, depreciação e custos financeiros sobre o processo de moagem e defloculação (ARAÚJO et al., 2001).

Com a introdução do processo de monoqueima rápida no Brasil, as plantas do APL de Santa Gertrudes começaram a se modernizar e se adequar ao novo processo. Em meados da década de 80, as empresas passaram a adotar a embalagem e classificação automáticas. No final dos anos 80 começaram a ser implantadas no Brasil as primeiras normas ISO e com a abertura dos mercados no início dos anos 90, os consumidores passaram a demandar maior qualidade dos produtos. No início dos anos 90 também foram adquiridos novos sistemas de preparação da massa que permitiram atingir menores granulometrias, melhorando o processo de granulação e umidificação. Com isso, a cerâmica de Santa Gertrudes passou a se aproximar da qualidade das cerâmicas produzidas por via úmida em Santa Catarina, apresentando custo significativamente menor.

Essa vantagem de custo ampliou as economias de escala já existentes na produção de cerâmica em Santa Gertrudes, uma vez que, mantidos os custos de transportes, a cerâmica de Santa Gertrudes seria competitiva em maior escala de mercado que a cerâmica de Criciúma.

Outros fatores conferiram vantagens ao APL de Santa Gertrudes, que se somaram às economias de escala proporcionadas pela moagem via seca. A localização 
privilegiada do pólo, perto de grande centro consumidor e servida por inúmeras rodovias, proporcionava custo de transporte menor que o pólo de Criciúma.

A indústria internacional de equipamentos teve papel fundamental na modernização do pólo, disseminando a tecnologia e facilitando o pagamento dos equipamentos. $\mathrm{O}$ grau de endividamento das empresas era pequeno, pois as aquisições de equipamentos foram feitas com recursos próprios, ou financiados em curto prazo. Algumas vezes os pagamentos estavam vinculados às vendas de cerâmica.

Algumas características das empresas locais também trouxeram vantagens, como a flexibilidade e rapidez na tomada de decisões devido ao menor tamanho e menos níveis hierárquicos.

\subsection{Empresas correlatas e de apoio - elos a montante}

\subsubsection{Mineração}

A mineração para abastecimento da indústria cerâmica é atividade tradicional na região. Devido ao baixo valor das argilas frente a outros bens minerais, a atividade de mineração na região não foi submetida a uma legislação adequada. Mesmo a partir de 1967, quando se tornou obrigatória a legalização mineral da atividade, a força do hábito e a falta de fiscalização e orientação do órgão federal competente fizeram com que essa situação se perpetuasse. A exigência da legalização, de fato, só viria a se concretizar com a pressão ambiental, já no final da década de 80. Essa conduta trouxe sérios transtornos às atividades atuais, tais como corrida e conflitos de titulações entre ceramistas e terceiros, conflitos de uso e ocupação territorial, atrasos em licenciamentos ambientais. O resultado é que muitos empreendimentos estão em situação precária de legalização, sujeitos à paralisação repentina das atividades.

A demanda atual das empresas ceramistas do APL de Santa Gertrudes é da ordem de 250.000 toneladas ao mês de argila local. Além de abastecer as empresas do APL, existe produção adicional de 15 a 20\% para atender empresas em outras localidades, como em Barra Bonita. O abastecimento de argila é efetuado por aproximadamente 20 minas ou mineradoras, de todos os portes: grande porte $(20$ a 35 mil toneladas/mês), médio porte (10 a 20 mil toneladas mês) e pequeno porte (em torno de cinco mil toneladas/mês). 
O fornecimento de argila pode se efetuar nas formas:

- argila bruta, extraída e fornecida com a umidade natural;

- argila seca, extraída com posterior secagem, em pátios abertos, ou com secagem forçada, nos municípios onde a secagem a céu aberto é proibida. Isso resulta em aumento do uso de secadores a gás, sobretudo nas maiores mineradoras; e,

- argila moída, quando a matéria-prima passa pelas etapas de extração e secagem sendo submetida aos processos de moagem e umidificação, nas chamadas centrais de massa. É a argila pronta para a prensagem, também denominada de massa pronta.

De forma simplificada, três tipos de empresas podem ser relacionadas, quanto ao vínculo, às cerâmicas e ao material produzido:

- mineradoras-beneficiadoras vinculadas às empresas cerâmicas. A maioria da extração de argila é feita pelas cerâmicas ou por empresas de mineração a ela vinculadas. As grandes empresas e grupos de empresas têm a sua própria jazida, fato que é destacado, esporadicamente, como garantia de qualidade. Podem ser relacionadas pelo menos uma dúzia de mineradoras vinculadas que produzem argila bruta e moída. A moagem da argila é feita, via de regra, nas instalações da cerâmica. Além de o fornecimento às cerâmicas do grupo, algumas vendem argila para terceiros. As minas operadas por essas empresas variam de pequeno a grande porte;

- mineradoras-beneficiadoras independentes: (centrais de massa) existem atualmente duas empresas produzindo massa pronta, com capacidade de produção da ordem de 30 e 20 mil toneladas/mês de argila moída, respectivamente. Essas empresas fornecem também argila bruta e seca. Recentemente, foi instalada na região representante de produtora de argila de Criciúma. Essa empresa vende massa via úmida e massa para porcelanato ${ }^{1} \mathrm{e}$

\footnotetext{
${ }^{1}$ Em pelo menos uma empresa do APL que possui prensas de alta capacidade, o porcelanato está sendo produzido em pequenas quantidades, a partir da massa comprada deste fornecedor.
} 
- mineradoras independentes: foram detectadas pelo menos seis empresas, que produzem argila bruta e seca. Uma delas é de grande porte, e as demais variam de pequeno a médio porte.

A produção de argila no APL de Santa Gertrudes ainda não atingiu o nível técnico padrão de mineração no Brasil, principalmente na aplicação de técnicas de geologia, engenharia mineral e em relação à legislação ambiental.

A produção de matérias-primas inclui a etapa de lavra, que corresponde às operações de remoção da cobertura vegetal e material estéril, desmonte, carregamento e prébeneficiamento do minério. Atualmente, essa etapa é realizada com equipamentos adequados não havendo pesquisa mineral, dificultando a atividade de planejamento e operação da lavra. A pesquisa mineral incorpora o conhecimento técnico especializado, apoiada em mapeamento, sondagens, descrições macroscópicas, ensaios e análises, para estabelecer o zoneamento dos tipos de minério.

Sem a pesquisa mineral não há conhecimento do perfil dos minérios contidos na jazida, dificultando os trabalhos de lavra, assim como a mistura e homogeneização, uma vez que os lotes apresentam grande variabilidade. A calibração dos equipamentos depende da experiência e sensibilidade dos operadores e técnicos. Os ensaios e análise são esporádicos, tanto nas minas, quanto nas plantas cerâmicas.

As variações nos lotes de argila são atenuadas e parcialmente compensadas por trabalhos no pátio. Isso não é totalmente eficaz, sempre há o risco do processo não ser totalmente adequado àquele lote específico. O resultado é verificado na saída do forno, com expressivas perdas.

Outro exemplo de conseqüência adversa, acarretada pela ausência de pesquisa geológica, é o abandono não previsto de frentes, provocado pelas surpresas por acidentes geológicos tais como intrusões de diabásio, falhas, fraturas e intemperismo, que mudam as características cerâmicas do minério.

\subsubsection{Fabricantes de equipamentos}

O principal país produtor de equipamentos para revestimentos cerâmicos é a Itália. As principais empresas produtoras mantêm filiações e assistência técnica e unidades industriais em vários países do mundo. O Brasil, um dos principais mercados 
mundiais de revestimentos cerâmicos, abriga filiais dessas empresas, mantendo atividades de produção de alguns equipamentos e de representação comercial de toda a linha. Essas empresas também fornecem esse tipo de serviço para outros segmentos da indústria, como cerâmica estrutural e construção civil.

O segmento produtor de equipamentos teve papel fundamental na origem e primeira fase do APL de Santa Gertrudes. Quando houve a modernização do parque produtivo, no final dos anos 80 , os fabricantes de máquinas levavam amostras das matérias-primas da região para testar e ajustar o equipamento na matriz. À medida que o conhecimento técnico foi se difundindo, a presença dos fornecedores foi sendo reduzida.

A maioria das empresas multinacional que hoje operam no Brasil iniciou suas atividades no país na década de 70, antes de a expansão do pólo de Santa Gertrudes. Inicialmente atuavam como representantes comerciais, depois com a instalação de algumas plantas.

Alguns fabricantes brasileiros, nacionais ou multinacionais, já produziram toda a linha de equipamentos no país. Alguns fatores como concentração mundial da indústria, estratégia de focalização e sobrevalorização do câmbio, levaram a indústria de equipamentos cerâmicos à tendência de retração, a exemplo dos demais segmentos do setor de bens de capital no país. Vários equipamentos deixaram de ser produzidos localmente e algumas empresas retornaram ao papel de representantes comerciais.

Atualmente, o mercado é dominado por três grandes empresas, duas multinacionais e uma nacional, mas também atuam pequenas e médias empresas. Somente as grandes fornecem toda a linha. Os equipamentos com maior conteúdo tecnológico, como prensas, linhas de esmaltação e serigrafia, são produzidas no exterior. No Brasil são fabricados os equipamentos mecânicos, utilizados na moagem e mistura, as multinacionais italianas produzem fornos. Duas empresas produzem secadores e atomizadores. A indústria também atua na reforma de equipamentos, principalmente de fornos. 
As pequenas e médias empresas internacionais fornecem equipamentos utilizados na primeira fase do processo. As nacionais atuam como fornecedoras de partes e peças às empresas maiores, incluindo calderaria, usinagem e tubulações.

A indústria produtora de equipamentos pode ser considerada a indutora de grande parte das inovações ocorridas no processo produtivo.

Nas primeiras fases do processo já se obteve significativos avanços de produtividade. Atualmente, as inovações nessas fases têm caráter predominantemente incremental, sem mudar os paradigmas tecnológicos, pois visam principalmente a redução de consumo de água e gás no processo e redução da poluição sonora e emissão de particulados.

As inovações mais representativas ocorrem nas fases pós-mistura, como prensas, esmaltação e queima, que têm maior impacto no desempenho estético e em que se concentram as possibilidades de diferenciação do produto, incluindo opções de tamanho da placa, variadas serigrafias e esmaltações. Nessas fases, atualmente, alguns novos paradigmas tecnológicos estão sendo introduzidos no mercado como a esmaltação por campana, as prensas rotativas, transferência de tinta a laser entre outros.

Apesar de algumas empresas multinacionais ofertarem toda a linha de equipamentos com atualização tecnológica, as atividades de Pesquisa e Desenvolvimento são realizadas nas matrizes.

A interação dos fabricantes de equipamentos com os ceramistas é intensa, especialmente quando o cliente ou a linha de produtos são novos. $\mathrm{O}$ mesmo não acontece entre os próprios fabricantes, que praticamente não se relacionam e atuam de forma isolada. Inexiste, também, qualquer relação entre esses fabricantes e a infraestrutura de ensino, pesquisa e serviços tecnológicos existente no estado de São Paulo.

\subsubsection{Colorifícios}

Os colorifícios são responsáveis pela produção de insumos químicos para a cerâmica de revestimento, que abrangem as fritas, compostos, engobes, granilhas, pastas cerâmicas, pastas serigráficas, corantes, tintas para decoração, preparadores de 
metais, lustres e esmaltes para vidros. É segmento que passou por profunda reestruturação nos últimos 20 anos. Inicialmente, os produtores eram originados de diferentes países, mesmo que não fossem grandes produtores de cerâmica. Os líderes eram a Colorobia (Itália), Degussa (Alemanha), Ferro Enamel e Johnson \& Mathey (EUA). Atualmente, as empresas espanholas dominam o mercado, todas localizadas na região de Castellón. Mesmo as grandes empresas de outros países contam com plantas e laboratórios na região (MEYER-STAMER et alii, 2000).

No Brasil, atualmente existem 17 empresas. As cinco maiores têm capacidade de 2.500 a 3.000 toneladas/mês e as demais entre 400 e 1.200 toneladas. Embora várias empresas nacionais participem do segmento na oferta interna de insumos químicos para cerâmica, é forte a presença de empresas estrangeiras, especialmente italianas e espanholas.

No APL de Santa Gertrudes existem vários colorifícios ou representantes, instalaram-se na região na década de 90. Tanto as empresas nacionais quanto as unidades brasileiras das empresas internacionais entrevistadas são principalmente de porte médio: contam entre 100 e 300 funcionários, produzem de 2 a 3 mil toneladas/mês e faturam de US\$ 700 mil a US\$ 3 milhões mensais.

A região de Santa Gertrudes é o mercado preferencial de todos os colorifícios entrevistados, uma vez que apresenta maior dinamismo em relação ao pólo de Criciúma. A importância atual do mercado de Santa Gertrudes faz com que os colorifícios mantenham estrutura especial de atendimento aos clientes do APL, que inclui entrega rápida e um conjunto de serviços agregados ao produto.

As cerâmicas de Santa Gertrudes priorizam o preço e os serviços agregados na compra dos insumos. Como os produtos do segmento são bastante parecidos, aproximando-se muito de commodities, a diferenciação possível ocorre nos serviços agregados, que compreendem toda a rede de assistência técnica, os serviços de atendimento e, principalmente, os laboratórios de design e desenvolvimento de novos produtos. Esses laboratórios possuem equipamentos de $\mathrm{CAD}$ e realizam o detalhamento do projeto de acabamento. Os serviços incluem disponibilizar designers, algumas vezes com exclusividade, além de formular e preparar esmaltes especiais. As empresas cerâmicas, principalmente as de menor porte têm os custos 
em relação ao design bastante reduzidos, por não necessitar manter equipes e equipamentos internamente. Muitas vezes, os colorifícios chegam a fornecer até as telas para a serigrafia. Para isso, mantêm contatos com escritórios de design no exterior (Itália e Espanha) e/ou são abastecidos pelos centros de tecnologia e design de seus respectivos grupos. Se por um lado as empresas cerâmicas reduzem seus custos, por outro os colorifícios arcam com pesados custos adicionais.

Os colorifícios, apesar da forte concorrência, constituem o elo de maior grau de cooperação, seja entre suas próprias empresas, seja com outros elos da cadeia. Entre as próprias empresas existem iniciativas de caráter tecnológico, como o desenvolvimento de engobes a prova de mancha d'água, pelo do Departamento de Engenharia de Materiais da Universidade Federal de São Carlos - UFSCar; e comerciais, como o projeto de compra conjunta de insumos importados, visando obter vantagens de preço na negociação de grandes volumes de itens como titânio, zinco, zircônio, cromo, cobalto, níquel, bórax, óxidos nobres e chumbo, que representam aproximadamente $60 \%$ do custo total de matérias-primas e insumos utilizados na fabricação.

A cooperação técnica dos colorifícios com a indústria de equipamentos existe, e é constante, devido às necessidades de adaptação para o processamento da matériaprima local. Existe cooperação na confecção de telas, ajustes em equipamentos e desenvolvimento de novas aplicações.

Os colorifícios também se distinguem por contato maior com a infra-estrutura de ensino e pesquisa existente no estado de São Paulo. O contato mais intenso ocorre com a UFSCar, mas um dos colorifícios entrevistados já utilizou os serviços do IPT e do SENAI.

A área ambiental é bastante propícia à cooperação com instituições de pesquisa. Exemplo é um projeto desenvolvido pela UNESP-Rio Claro para reaproveitamento da raspa, que é o excesso de engobe e esmalte que cai no chão, ao longo da linha de esmaltação e que não tem destino, pois a CETESB impõe restrições à sua reutilização.

Apesar da atualização tecnológica das empresas do segmento, elas seguem as tendências internacionais, hoje ditadas principalmente pela Espanha, líder mundial 
em esmaltação. Os esforços internos restringem-se, na maior parte, a adaptações de produto e processo às matérias-primas e demais condições locais.

De maneira geral, os avanços tecnológicos na fase de esmaltação são constantes e as empresas que aqui operam se mantêm atualizadas. Apesar do patamar tecnológico atingido, inclusive no que se refere à adoção de tecnologias limpas (com reaproveitamento da água utilizada no processo e redução da emissão de poluentes), os colorifícios brasileiros se reportam aos grandes centros ecnológicos e de design na Itália e na Espanha para a observação de tendências e a adoção de melhorias.

Todas as empresas entrevistadas mantêm Departamento Técnico ou equivalente, que realiza atividades de design (desenvolvimento de produtos) e presta variadas assessorias às empresas cerâmicas, em uma área de assistência técnica e/ou de atendimento ao cliente, que pode ou não estar acoplada à área de design. Esses Departamentos possuem designers que realizam a interface entre os fornecedores estrangeiros de desenhos e a produção, reproduzindo em escala piloto as novas peças. Os designers, além de traduzirem as tendências estéticas internacionais para o mercado doméstico, são responsáveis pela maquinabilidade dos novos produtos, pois as estampas devem ser impressas em peças feitas com matéria-prima local e em condições muito particulares, como a via seca, baixo tempo de queima. Além de a tradução dos motivos estéticos em voga internacionalmente para o mercado local, os departamentos de design de algumas empresas também realizam adaptações e criação de desenhos. As iniciativas de criação não são bem sucedidas, dada a preferência dos empresários do setor por motivos já testados e aceitos pelo mercado.

Além de designers, as empresas possuem engenheiros e técnicos de nível médio que prestam serviços de assistência técnica e fornecem assessoria de processo às empresas cerâmicas. Essas atividades implicam, em alguns casos, a existência de grandes instalações, que reproduzem em escala piloto variadas fases do processo cerâmico.

Os colorifícios adquirem os desenhos de terceiros, pelos quais pagam entre US\$ 500 e US\$ 1.000, ou seja, não internalizam a concepção estética dos produtos. Mantêm bancos de dados com milhares de desenhos, que são exibidos ao cliente para escolha. 
Uma vez definida a estampa, o trabalho do departamento de design ou equivalente é transformar o desenho em peça.

O estreito contato do colorifício com a indústria cerâmica propicia uma série de melhoramentos incrementais em produtos e processos, o que significa que este elo da cadeia está constantemente produzindo pequenas inovações, além de outras significativas, como o corante micronizado de alta dispersão ou a serigrafia por jato de tinta. Essas inovações abrangem desde o desenvolvimento de novos produtos novas formulações de esmalte, técnicas de maior resistência do produto à abrasão, preenchimento de poros na fase de polimento, desenvolvimento de vidrados, engobes e tintas como suporte à atividade de design - até alterações no processo - adequação da massa e da matéria-prima ao processo, novos processos (como serigrafia por jato de tinta), ajustes para redução dos danos ambientais.

\subsubsection{Instituições de Pesquisa, Ensino e Apoio}

O Brasil dispõe de variadas instituições e laboratórios que podem atender de modo segmentado o setor cerâmico de revestimento. Os laboratórios e instituições mais atuantes no APL de Santa Gertrudes são o Laboratório do Centro Cerâmico do Brasil - CCB - de Santa Gertrudes, laboratórios da Universidade Federal de São Carlos UFSCar, Escola SENAI Mário Amato - Cerâmica e o Instituto de Geociências da UNESP Rio Claro.

A UFSCar, além de formar engenheiros de materiais, que lentamente ocupam postos nas indústrias de revestimentos cerâmicos, dispõe de uma série de laboratórios. Dentre eles, destaca-se o Laboratório de Revestimentos Cerâmicos (LaRC), no Departamento de Engenharia de Materiais, além de atuar centrado em placas cerâmicas, promove articulação entre o setor produtivo e as instituições técnicocientíficas. Alguns projetos envolvem novas formulações e técnicas de preparação de massa, aprimoramento na esmaltação (eliminação da mancha d'água) e cursos de atualização. Outro laboratório instalado na UFSCar é o CCDM (convênio com a UNESP Araraquara), bem aparelhado, que atua na caracterização de materiais diversos e em cursos de atualização, mas não especificamente em produtos cerâmicos. Outros laboratórios atuam ou apresentam instalações voltadas à pesquisa em processamento térmico e em design. 
A Escola SENAI Mário Amato, com sede em São Bernardo do Campo, tem deslocado para Santa Gertrudes alguns cursos especiais de formação de técnicos cerâmicos. A infra-estrutura de ensino é parcialmente utilizada para prestação de serviços.

A Universidade Estadual Paulista Júlio de Mesquita Filho - UNESP - campus de Rio Claro, além de colaborar na formação de profissionais (geólogos, geógrafos, biólogos etc) que atuam, ainda de forma incipiente, na pesquisa geológica e no trato ambiental da cadeia cerâmica, principalmente por meio de empresas de consultoria; busca, pelo setor de geologia, se inserir na base da cadeia produtiva local, com mapeamento geológico, caracterização de matérias-primas e meio ambiente.

O CCB, em parceria com a ASPACER, montou em Santa Gertrudes o CITEC. O Centro deve continuar o trabalho do CCB na certificação de produtos, realização de ensaios físicos, e visitas freqüentes às empresas, levando apoio técnico e incentivando a implantação de políticas de qualidade. Além disso, são disponibilizados vários cursos e treinamentos para a mão-de-obra local.

\subsection{Empresas correlatas e de apoio - elos a jusante}

\subsubsection{Segmento de distribuição}

As atividades de marketing e distribuição estão entre aquelas que auferem maiores margens e detêm a governança das cadeias produtivas, mormente em produtos tradicionais de consumo final, como alimentos, vestuário, calçados.

No caso da cerâmica de revestimento fabricada no cluster de Santa Gertrudes, verifica-se que, enquanto o preço do produto posto-fábrica gira em torno de U\$ 1,3 a $2,0 / \mathrm{m}^{2}$, o consumidor final paga em torno de U\$ 3 a $6 / \mathrm{m}^{2}$. Agregando-se a esse valor o custo do assentamento do produto, em torno de U\$ $5 / \mathrm{m}^{2}$, verifica-se que a apropriação da indústria cerâmica fica por aproximadamente $15 \%$ do valor gerado na cadeia produtiva. As atividades de distribuição e assentamento da cerâmica, grosso modo, geram seis vezes mais receita que sua produção.

\subsubsection{Extensão da rede de distribuição}

Segundo dados obtidos junto à ANAMACO, existem 103 mil lojas de revenda de materiais de construção no Brasil. Dessas, $47 \%$ comercializam cerâmica de 
revestimento. Trata-se de sistema extremamente pulverizado, distribuído geograficamente aproximadamente na mesma proporção do PIB de cada região.

Dados da ANAMACO com base em amostra de 1352 revendedores de materiais de construção, consultados entre 22/12/2000 e 31/01/2001, mostram que 55\% dos revendedores são pequenas empresas de até dez funcionários, $42 \%$ têm de 10 a 100 funcionários e apenas 3\% têm mais de 100 empregados. Nenhuma das marcas de cerâmica consegue ter alcance preponderante sobre esta rede de distribuição. A marca com maior penetração na rede está presente em 39\% dos revendedores. Já o maior índice de marca mais lembrada é de apenas 10\% dos revendedores.

\subsubsection{Assentamento}

Os produtos concorrentes dos revestimentos cerâmicos, como laminados de madeira, pisos de borracha, carpetes, entre outros, em geral são vendidos instalados e com garantia. Desta forma o consumidor se exime dos custos e contratempos de contratar mão-de-obra, além de ter garantia de reposição ou ressarcimento, caso o desempenho do produto instalado não seja satisfatório.

Para a cerâmica, como foi visto, o assentamento tem valor três a cinco vezes maior que o preço do produto, cabendo ao consumidor a contratação de mão-de-obra. As fábricas, em geral, e as de Santa Gertrudes, em particular, não fornecem garantia quanto ao desempenho do produto assentado.

O assentamento é reconhecido pelos industriais e comerciantes como a fonte de maiores conflitos junto aos consumidores. Os problemas de assentamento têm origem desde a escolha inadequada da cerâmica frente as suas especificações em relação à absorção de água e resistência mecânica e à abrasão, e incluem o mau preparo do contrapiso, argamassas inadequadas, rejuntes aplicados precocemente, até a utilização de produtos de lotes e dimensões distintos.

De fato, algumas vezes, os conflitos são solucionados pelos órgãos de defesa do consumidor e centralizados pela fábrica, sem participação, portanto, de representantes e revendedores.

Algumas ações têm sido empreendidas pela indústria cerâmica para melhorar a qualidade do assentamento. Entre elas está o PROFORMA, programa de parceria 
entre ANFACER, SENAI, SINDUSCON, SEBRAE, Ministério do Trabalho, Prefeituras e Secretarias de Estado do Trabalho e tem como objetivo a qualificação e requalificação de profissionais para assentamento cerâmico, mediante cursos de até 40 horas. Desde o seu início, em 1992, até 2001, o PROFORMA havia formado aproximadamente 38 mil assentadores.

Os formados pelo Proforma têm seus nomes divulgados pela Internet por meio do site da ANFACER. O SENAI Orlando Laviero Ferraiuolo, no bairro do Tatuapé em São Paulo, capital, também forma assentadores de cerâmica em um curso de 80 horas, que tem como pré-requisito que o aluno tenha freqüentado cursos de pedreiro e de revestimento.

Há que se destacar que esses esforços ainda não geraram efeitos significativos sobre os problemas do assentamento. O número de profissionais formados é ainda bastante pequeno em relação às necessidades do mercado brasileiro. Após formados, os assentadores não são distinguidos pelo consumidor. Pode-se atribuir esta indiferenciação aos seguintes fatos:

1) não há formalização contratual entre assentadores, revendedores e indústria cerâmica;

2) não há vínculo entre a contratação desses assentadores e garantia do produto assentado;

3) não há sistema de certificação que acompanhe a atuação dos assentadores e os reavaliem periodicamente;

4) não se estabeleceram normas de conduta e formação de preços, para os diferentes tipos de cerâmica e suas aplicações.

\subsection{Empresas cerâmicas}

\subsubsection{Estratégia competitiva}

\subsubsection{Mercado}

O principal fator competitivo das empresas entrevistadas é sempre o preço. Outros atributos considerados importantes ambém são qualidade (design), prazo de entrega, durabilidade e serviços pós-vendas. A participação de produtos novos no faturamento 
da empresa é bastante alta, sendo que há no mínimo dez lançamentos de produtos por ano até dez referências por mês. O preço médio do produto comercializado varia entre $\mathrm{R} \$ 2,5$ até $\mathrm{R} \$ 7,0$.

As empresas atendem quase todos os estados do Brasil, com destaque para o Sudeste (São Paulo e Rio de Janeiro). Metade das empresas exporta para o Mercosul, majoritariamente.

Uma das empresas do pólo adotou a estratégia de instalar duas plantas produtivas no estado da Bahia, uma para a produção via seca, com produtos baratos, e outra para produção via úmida, com produtos de maior valor agregado. A empresa alega que estava perdendo mercado no Nordeste e que a opção pela Bahia se deve a condições logísticas e de oferta de matéria-prima.

\subsubsection{Produção}

\subsection{Recursos Humanos}

Uma característica predominante no pólo de Santa Gertrudes é a presença de pessoas da família em cargos de diretoria (todas as empresas entrevistadas). Com relação à escolaridade, a percentagem média de funcionários com curso superior é 2,5\%, sempre mais que $70 \%$ tem o ensino fundamental completo, $25 \%$ tem ensino médio concluído. A origem dos funcionários pode ser própria cidade onde está localizada a empresa, a região de Rio Claro, estado de Minas Gerais (mão-de-obra não especializada) e de Santa Catarina (mão-de-obra especializada).

As empresas declaram ter dificuldades para encontrar técnicos qualificados na área de cerâmica, eletrônica e mecânica.

A terceirização da mão-de-obra ocorre nas seguintes áreas: departamento jurídico, saúde, informática, portaria, manutenção, segurança, refeitório e usinagem.

\subsection{Sistema de financiamento}

As principais fontes de financiamento para a aquisição de equipamentos e melhoria das plantas são o FINAME, bancos privados e os próprios fornecedores de equipamentos. 
As principais áreas que tiveram investimento nos últimos cinco anos foram a expansão da capacidade por meio de aquisição, instalação de novas plantas e modernização das plantas existentes.

Para o financiamento em curto prazo, os fornecedores de insumos sintéticos (colorifícios) possibilitam pagamento de 45 a 60 dias após entrega. O fornecimento de gás estipula prazos de 20 dias. O fornecimento de matéria-prima é pago mensalmente.

\subsection{Sistema de Produção e Inovação}

No pólo de Santa Gertrudes, 11 empresas têm seus produtos certificados pelo CCB, o que significa $26 \%$ do total e 5 empresas (12\%) possuem certificação ISO 9002 para fabricação e comercialização de placas cerâmicas (CCB, 2003).

Todas as empresas entrevistadas produzem para estoque e duas produzem por encomenda. O estoque médio das empresas varia entre 30 e 60 dias. Esse nível é bastante superior à média histórica. Os empresários atribuem esse aumento nos níveis de estoque a duas causas: a primeira é o racionamento de energia, que ocasionou retração na demanda e a segunda é a super oferta de produtos, ocasionada pela expansão da capacidade produtiva no pólo. ${ }^{1}$ Mesmo assim, o nível de estoque em Santa Gertrudes é menor que o das empresas de Santa Catarina.

Os sistemas de programação e controle da produção das empresas são de três tipos: manual, mecanizado desenvolvido internamente e adaptação de sistemas MRP.

Os principais gargalos no sistema de produção apontados pelas empresas entrevistadas são a padronização da qualidade e controle do mix da argila, a falta de qualificação da mão-de-obra, problemas no forno, na qualidade do esmalte devido a falhas na pesagem dos insumos e perdas e quebras no processo de esmaltação.

As principais ações realizadas para resolver os problemas na argila são a conferência dos lotes e acompanhamento da extração. A questão da mão-de-obra é resolvida com treinamento intensivo no local. Os problemas com o esmalte são solucionados por

\footnotetext{
1 A pesquisa foi realizada entre maio e julho de 2001, quando houve o racionamento de energia elétrica no estado de São Paulo.
} 
meio de treinamento dos funcionários na operação e na pesagem, assim como ajustes na formulação.

As empresas adotam inovações no processo com muita frequiência. No caso das empresas entrevistadas, uma havia mudado o processo de mistura de via seca para via úmida, conseqüentemente mudou toda a linha de produtos. Outras empresas, nos últimos dois anos, adquiriram novos fornos, prensas, equipamentos para secagem e automação da produção. Mas a maior parte das inovações foi no sistema de esmaltação, com a introdução de sistema à vela para a aplicação do esmalte, campana pressurizada para a aplicação do engobe e melhoria no processo de moagem para melhorar a granulometria do esmalte.

As inovações no processo são introduzidas por meio de cooperação com fornecedores de insumos, aquisição de máquinas no mercado internacional, cooperação com fornecedores de equipamentos e assistência técnica.

A aquisição de inovações tecnológicas no produto é constante, tanto no esmalte, como no corpo cerâmico. A redução na absorção de água, utilização de normas para a formulação da mistura na matéria-prima, a desutilização de chumbo são inovações introduzidas na massa cerâmica. $O$ esmalte e o engobe também foram objetos de melhoria, com novas formulações para o esmalte, desenvolvimento de engobe impermeável em conjunto com os fornecedores de insumos, como a redução da camada de engobe.

As idéias para novos produtos têm origem em propostas dos colorifícios e oferta de novos equipamentos (linha de esmaltação) com observação do mercado. O prazo para desenvolvimento de novos produtos varia entre uma semana e dois meses.

\subsubsection{Cooperação}

\subsubsection{Cooperação horizontal}

A cooperação horizontal é bastante incipiente, principalmente a multilateral. Um dos principais esforços de cooperação horizontal multilateral é a tentativa de definição de preço mínimo para os produtos de Santa Gertrudes, ação que não foi bem sucedida.

Existem duas instituições de apoio com maior representatividade local: a ASPACER - Associação Paulista de Fabricantes de Cerâmica e o Sindicato das Indústrias da 
Construção e do Mobiliário de Santa Gertrudes A maioria dos empresários entrevistados (cinco) são sócios destas instituições, sendo que dois são diretores de uma das duas. A participação na CIESP de Limeira e no CCB ocorre com menor intensidade.

A cooperação horizontal bilateral ocorre com maior freqüência, na forma de troca de informações e experiências e empréstimo de peças para manutenção. Nas empresas do mesmo grupo familiar também ocorre o empréstimo de funcionários.

\subsubsection{Cooperação vertical multilateral}

A cooperação vertical multilateral é muito difícil por falta de agente coordenador da cadeia. O CCB tem realizado esforços para provocar melhor integração entre a indústria cerâmica, a comercialização e o assentamento, se aproximando desta função.

\subsubsection{Cooperação vertical bilateral a montante - fornecedores de matérias- primas}

A cooperação vertical com os fornecedores de matérias-primas é substituída pela internalização das atividades de mineração. Quando a relação é com fornecedores externos, observam-se problemas de preço e constância de fornecimento. Outro problema identificado é que a homogeneização da massa é feita sem pesquisa de jazida.

No caso da cerâmica via-úmida, mais representada em Santa Catarina, a massa é composta de várias matérias-primas, provenientes, em parte, de produção própria e, o restante, de terceiros. Ocasionalmente, toda a matéria-prima provém de terceiros. Em entrevista com fornecedores, observou-se que é freqüente a solicitação de parceria com os consumidores, alegando baixo poder de investimento e preço baixo de venda. Citaram a falta de contratos em longo prazo ou outra garantia de compra que assegure investimentos mais sofisticados nas jazidas. Os consumidores alegam que simpatizam com parceria, oferecem algum tipo de apoio, mas não podem se comprometer com contratos mais longos, devido à falta desses contratos à jusante. Observa-se que os consumidores sempre buscam manter pelo menos dois fornecedores para cada matéria-prima, quando comprada de terceiros. 
A relação com os consumidores é comercial, por meio das compras de lotes com prazo de entrega, que são analisados antes do embarque. No caso de empresas mineradoras ligadas a empresa cerâmica, a compra é preferencial, desde que atendido os quesitos qualidade e preço.

No caso da via seca o sistema é diferente, dada a peculiaridade da formulação da massa. Como esta é composta apenas de argila, que no máximo é extraída de duas minas diferentes, existe apenas um fornecedor, que pode ser dos três tipos anteriormente referidos. As mineradoras ligadas às empresas cerâmicas perfazem a maior parte da produção, de forma a atuarem em sintonia. A relação com terceiros é feita sem contrato, como se trabalha com volumes maiores (de 30 a 200 toneladas/dia) a relação parece ser estável. É freqüente atribuir-se à matéria-prima de terceiros a maior parte dos defeitos que surgem na produção, fato que é parcialmente rechaçado pelo produtor. Reconhece-se que a falta de pesquisa pode acarretar em alguns lotes problemáticos, pois é feito controle apenas na frente de lavra.

\subsubsection{Cooperação vertical bilateral a montante - fornecedores de equipamentos}

A cooperação vertical com fornecedores de equipamentos é intensa na forma de troca de informações, obtenção parcial de crédito, negociação de prazo de entrega e desenvolvimento conjunto de melhorias.

Esse elo da cadeia tem papel de destaque na difusão do progresso técnico. Esse papel foi mais visível no início da implantação do APL, quando os fornecedores de equipamentos chegavam a levar amostras das matérias-primas da região para decidir pela melhor combinação de máquinas para uma nova planta. À medida que o conhecimento técnico se difunde, o fornecedor de equipamentos passa a supervisionar a montagem, pois a tecnologia é conhecida e o próprio cliente acaba optando por executar a montagem ou contratar tal serviço no mercado, em função da diferença de preço. ${ }^{1}$

\footnotetext{
${ }^{1}$ Um exemplo dessa relação foi a recente montagem da unidade de porcelanato da Portobello, em Santa Catarina, pela Sacmi. A interação compreendeu a produção experimental, na Itália, do que seria feito na planta; o treinamento do pessoal da empresa e toda a assistência, até o funcionamento da unidade.
} 
Apesar de a estreita relação com os fornecedores de equipamentos, especialmente no início da implantação do parque, adaptações para a produção de cerâmica de revestimento por via seca foram feitas pelas próprias empresas do pólo, sem a participação dos técnicos italianos. Segundo entrevistas realizadas, o processo por via seca brasileira não é o italiano, mas sim o resultado de um conjunto de soluções locais, encontradas na base da tentativa e erro (learning by doing).

O pólo de Santa Gertrudes representa hoje de 50 a $70 \%$ das vendas das empresas de equipamentos entrevistadas e priorizam na compra, segundo estas empresas, fatores como assistência técnica (serviços associados), tradição, confiança na marca, qualidade do produto e relacionamento interempresas.

Como toda a produção é sob encomenda, não existem intermediários entre os fabricantes de equipamentos e a indústria cerâmica. O tempo médio de fabricação de uma linha completa de equipamentos é de seis a oito meses, contados a partir do recebimento do pedido. São comuns as operações FINAME $^{1}$ para a aquisição de equipamentos, assim como o uso de recursos próprios e de financiamento externo, acoplado à compra.

\subsubsection{Cooperação vertical bilateral a montante - colorifícios}

A cooperação vertical com fornecedores de insumos também é intensa, ocorrendo na forma de desenvolvimento conjunto de novos produtos, troca de informações e experiências. Essa relação não tem compromisso formal e existem variações no preço e a maioria das empresas cerâmica não tem acesso à formulação do esmalte, o que implica problemas de ajustes operacionais na linha de esmaltação.

A relação dos colorifícios com a indústria cerâmica de Santa Gertrudes é bastante estreita, conforme ficou demonstrado. Uma vez efetuada a operação de venda, normalmente o assistente técnico tem rotina de visitas às empresas, de forma que a relação é retroalimentada a contento. As formas assumidas por essa relação são várias: desenvolvimento conjunto de produtos, assessoria de processo, variados apoios tecnológicos, negociações de prazo de pagamento e trocas de informações. A

\footnotetext{
${ }^{1}$ Financiamentos do Banco Nacional do Desenvolvimento Econômico e Social - BNDES - sem limite de valor, para aquisição isolada de máquinas e equipamentos novos, de fabricação nacional.
} 
natureza da relação reforça o papel dos colorifícios como os grandes fornecedores de tecnologia - e especialmente de design - para a indústria cerâmica.

A localização no próprio pólo, dado o elevado grau de cooperação existente entre os dois elos, é hoje importante requisito. Mesmo os colorifícios que tem a planta produtiva fora da Região mantém no pólo um escritório de vendas, assistência técnica e atendimento ao cliente, que inclui as atividades de design. $\mathrm{O}$ atendimento ao cliente em sistema do tipo just in time, entrega das encomendas no momento, nas condições e no volume requerido, ${ }^{1}$ é requisito que só as empresas que têm unidade de produção muito próxima ao pólo podem satisfazer. O aspecto da localização da produção, dada a sensível diferença entre o dinamismo dos pólos de Santa Gertrudes e Criciúma, já é motivo de inquietação por parte de alguns colorifícios do sul.

A busca de diferenciação pela agregação de serviços aos produtos, iniciada pelos colorifícios como forma de expansão do mercado e fidelização de cliente, é generalizada nas empresas do segmento. Esses serviços implicam a manutenção de pesadas instalações, que incluem laboratórios de análise e, em alguns casos, até plantas-piloto. Se de um lado esse arranjo, aparentemente, traz benefícios para as empresas cerâmicas, por outro desestimula o desenvolvimento de capacitação tecnológica própria, especialmente em desenvolvimento de produtos e design.

\subsubsection{Cooperação vertical bilateral a montante: instituições de pesquisa}

O desenvolvimento do APL de Santa Gertrudes ocorreu pela própria indústria, em suas relações com os fornecedores. As inovações tecnológicas foram e são adquiridas por esses fornecedores, sem a interação com as instituições de pesquisa.

As instituições sempre buscaram outras fronteiras de pesquisa, não relacionadas à cerâmica tradicional.

A realidade brasileira nos últimos anos - alto desempenho da indústria de revestimento em contraste com a saturação das áreas preferidas dos pesquisadoresaliada ao ressurgimento de centros de pesquisa de sucesso em cerâmica tradicional, como na Espanha (Instituto de Tecnologia Cerâmica), Itália (Centro Cerâmico de

\footnotetext{
${ }^{1}$ Os colorifícios geralmente trabalham com estoques de segurança de corantes e fritas (15 dias).
} 
Bolonha) e Estados Unidos (Whiteware Ceramic Center - NYU), despertaram o redirecionamento de alguns núcleos de pesquisa para revestimentos cerâmicos.

No trabalho de Piva e Pacheco (1997), são relacionadas várias atividades de pesquisa que as empresas poderiam desenvolver em parceria com as instituições, como projetos de pesquisa e desenvolvimento de protótipos e processos, apoio técnico e transferência de tecnologia. Embora haja motivação para a cooperação, os autores afirmam que a diferença de cultura entre os dois lados é bastante acentuada. Por um lado, a visão das instituições e o gosto pela pesquisa, leva a soluções em longo prazo e distanciamento da realidade empresarial; por outro lado, os empresários buscam eliminar riscos de comprometimento dos lucros.

Atualmente, a cooperação vertical instituições de pesquisa e treinamento ocorre com as seguintes instituições: CCB, UFSCar, CCDM e UNESP.

A aproximação entre empresas e instituições ainda não é satisfatória, mas evolui-se mediante alguns convênios de cooperação entre instituições e empresas ou coletivo de empresas, contando com apoio parcial de agências de fomento.

\subsubsection{Coope ração horizontal bilateral a jusante: distribuidores e agentes de comercialização}

O principal agente de comercialização é o representante autônomo, que comercializa vários produtos em conjunto. A relação com as lojas de materiais de construção é um gargalo, ocorrendo alguma cooperação na forma de troca de informações, experiências e especificação dos produtos. Existe parceria com o CCDM que realiza trabalho com os representantes. O peso percentual de distribuição, segundo as empresas entrevistadas é de 40 a $60 \%$.

As fábricas de cerâmica de Santa Gertrudes, normalmente, não têm qualquer controle sobre a logística de distribuição de seus produtos. Os compradores ou representantes são os responsáveis pela contratação de serviços de transporte, permitindo ineficiências nas rotas, equipamentos e custos de transporte.

Para fazer frente a uma estrutura de distribuição pulverizada, as indústrias cerâmicas do APL de Santa Gertrudes se valem de representantes independentes, com praças de trabalho delimitadas. Das entrevistas realizadas depreende-se que os representantes 
comerciais têm o objetivo de maximizar o volume de vendas, não necessariamente, nas condições mais favoráveis para a indústria. Muitas vezes, os representantes comerciais atuam mais como agentes dos varejistas que, mais propriamente, dos industriais.

Outro aspecto fundamental na relação com revendedores e clientes é o baixo investimento em marcas. Os industriais cerâmicos de Santa Gertrudes consideram seu produto commodity. Produtos indiferenciados que qualquer um dos fabricantes poderia produzir, não só pela possibilidade de cópia, porque o investimento no design de novo produto é feito, eminentemente, pelos colorifícios. Acrescente-se que, como muito pouco valor é agregado ao produto, em termos de bgística ou apoio ao consumidor, de fato os produtos passam a ter esse caráter indiferenciado. Esta estratégia, por seu turno, implica, necessariamente, em competição baseada em preços e compressão de margens.

Recentemente, a partir de maio de 2001, observa-se competição mais acirrada no mercado de revestimento cerâmico devido à retração econômica brasileira neste período. Resultando em compressão crescente nas margens da indústria em favor do elo da comercialização. Frente a isto, os estoques que normalmente tinham volume de 30 dias de produção, passaram a atingir até 60 dias. Dessa forma, tende-se a produzir volume maior de produtos indiferenciados e de baixo preço, como estratégia de redução do risco de encalhe de estoques.

\subsubsection{Cooperação horizontal bilateral a jusante: exportação}

As exportações da indústria cerâmica em Santa Gertrudes são em montante bastante reduzido (entre 5 e $10 \%$ da produção), atingindo preferencialmente os países do Mercosul e América do Sul. Identificou-se em apenas uma das empresas a contratação de profissional com missão de impulsionar as vendas para o mercado externo. Mesmo assim, a estratégia está calcada, eminentemente, no oferecimento de preços baixos.

\subsubsection{Cooperação horizontal bilateral a jusante: serviços pós-venda}

As indústrias cerâmicas de Santa Gertrudes não possuem estruturas de serviços pósvenda, possuindo atendimento de reclamações de consumidores. Esse atendimento é centralizado na fábrica, não havendo representantes regionais com capacidade 
decisória para gerir conflitos e encaminhar as reclamações. Não se observa nenhuma assistência sistemática ao consumidor, referente às diferentes especificações e aplicações do produto, projetos de engenharia e assentamento final. Naturalmente, os vendedores da rede varejista, os engenheiros e arquitetos de projetos de edificações conhecem as especificações, aplicações e restrições dos revestimentos cerâmicos. A escolha por determinado produto, em geral, é feita sem nenhuma articulação ou estímulo sistemático por qualquer uma das indústrias cerâmicas de Santa Gertrudes. 


\section{VALIDAÇÃO DO MODELO CONCEITUAL}

O modelo apresentado no capítulo 3 procura representar a dinâmica de evolução dos APL's. Breve discussão foi feita naquele capítulo, tentando verificar a pertinência do modelo para alguns APL's brasileiros. O objetivo deste capítulo é validá-lo frente ao APL de Santa Gertrudes. Para tanto, cada hipótese do modelo será discutida a partir dos dados secundários e os levantados localmente.

\subsection{Origem do APL de Santa Gertrudes}

A produção de cerâmica de revestimento apresenta grandes economias de escala em várias fases de seu processo. Moinhos, prensa, linha de esmaltação e forno são equipamentos que aumentam a produtividade unitária com o seu tamanho.

Cada uma das etapas do processo já apresentou mudanças em seus paradigmas tecnológicos, a partir dos anos 60, possibilitando a adoção de inovações revolucionárias e de surgimento de APL's. O APL de Sassuollo, por exemplo, beneficiou-se das economias de escala obtidas na mudança de paradigma de queima dupla para queima simples.

A inovação fundamental para o surgimento do APL de Santa Gertrudes foi a adaptação da matéria-prima local ao processo de mistura via seca, com menores custos de energia. Esse processo, exigia propriedades da matéria-prima que não eram atendidas pela argila de formação Corumbataí de Santa Gertrudes. Experimentos realizados pelos próprios empresários locais, com mudança em alguns parâmetros do processo, lograram sucesso na produção de cerâmica de revestimento por via seca com matéria-prima farta e barata. Atualmente, o custo de produção de Santa Gertrudes é aproximadamente $30 \%$ do custo de Criciúma.

A capacitação existente na indústria de cerâmica estrutural foi fundamental. Os empresários locais possuíam experiência na extração da matéria-prima e conheciam a argila local. Eles testaram e adaptaram o processo via seca à argila de formação Corumbataí, abundante na região, contra previsões dos próprios fabricantes de equipamentos, que não acreditavam ser possível produzir cerâmica de revestimento 
com argila local. A adaptação dos fornos "garrafão", originalmente usados na produção de telhas, também contribuiu para favorecer a implantação do APL. Outro fator importante foi a qualificação da mão-de-obra, usada intensivamente, que também tinha algum conhecimento do processo. A rede de distribuição, utilizada para a comercialização de telhas e a proximidade a um grande centro consumidor com infra-estrutura de transportes diferenciada em relação a outros estados brasileiros foram outros fatores que favoreceram a competitividade da localização em Santa Gertrudes. O peso locacional da cerâmica foi estimado em 2,1. Pesos locacionais maiores que 2 induzem a concentração próxima à matéria-prima.

\subsection{Evolução do APL de Santa Gertrudes}

O APL de Santa Gertrudes apresentou uma dinâmica evolutiva que se ajusta ao modelo proposto, tendo passado pelas fases embrionária e de crescimento e agora mostra sinais de estar entrando na fase de maturidade. As diversas hipóteses sobre a evolução das economias externas e internas também se ajustam, com algumas exceções, ao modelo.

\subsubsection{Fase embrionária de Santa Gertrudes}

Desde sua origem nos anos 70 até o início da década de 90, o APL de Santa Gertrudes passou por uma fase embrionária, aproveitando as economias de escala e de custos obtidas da adaptação do processo via seca, utilizando tecnologia obsoleta em outras fases do processo, sem preocupação com qualidade e produzindo produto sem diversidade. As principais hipóteses para o comportamento do APL nesta fase, a competição por custo, a cooperação horizontal de caráter técnico e informal, a cooperação técnica incipiente com a indústria de equipamentos se verificaram no caso do APL de Santa Gertrudes.

A redução no custo de produção ampliou as vantagens de escala de Santa Gertrudes, pois mantidos os mesmos custos de transportes, a cerâmica de Santa Gertrudes seria mais competitiva em um raio maior de mercado. 


\subsubsection{Fase de crescimento de Santa Gertrudes}

Na evolução do agrupamento de Santa Gertrudes é possível notar dois pontos de inflexão no tempo - turning points - (SCHMITZ, 1994), um no início da década de 90, quando se inicia o estágio de crescimento e outro no início da década de 2000, quando se inicia a maturidade.

No final dos anos 80 e início dos anos 90, o APL entra em fase de crescimento, quando uma série de inovações foi adotada no processo de produção. Neste período, os produtores de equipamentos exerciam papel fundamental na consolidação do arranjo. Estas empresas contavam com várias plantas e representantes no Brasil, antes mesmo da implantação e consolidação do APL.

Nesta fase também começam a se instalar na região os primeiros colorifícios, iniciando a parceria para o desenvolvimento de esmaltes e design que se estabelece ao longo da década de 90. As instituições de apoio e pesquisa passam a ter maior interesse nas empresas do arranjo.

No início dos anos 90, com a modernização das plantas, leis ambientais mais rigorosas e consumidor mais exigente, o APL passa a competir com o mercado de Santa Catarina e outros pólos em São Paulo.

A modernização dos moinhos para produção via seca, e a oferta de outros equipamentos modernos, como os fornos para monoqueima rápida, as linhas de classificação e embalagem proporcionaram aos produtores de cerâmica de Santa Gertrudes adquirir equipamentos com alta produtividade, por financiamentos pagos segundo as vendas dos ceramistas, freqüentemente bancados pelos próprios fabricantes de equipamentos. Dessa forma, as empresas de Santa Gertrudes mantiveram baixo grau de endividamento frente às grandes empresas de Santa Catarina. A produção de telhas é abandonada pelos produtores de cerâmica que, em conjunto com a mão-de-obra, passam a se especializar na produção de cerâmica de revestimento.

A difusão de tecnologia incremental, responsável pelos spill overs tecnológicos, também foi papel exercido pela indústria de máquinas, dado que disponibilizava assistência técnica para a adaptação dos novos equipamentos às condições locais de 
matéria-prima e capacitação. A indústria de máquinas também passou a ser veículo de transmissão de conhecimento tácito gerado nas empresas.

A cooperação de caráter técnico com produtores de equipamentos se intensifica, para a adaptação de equipamentos modernos às condições locais. Os produtores de equipamentos chegam a levar amostras de argila para a Itália para ensaiá-las. A cooperação horizontal tem caráter informal e estabelece-se na disponibilização de funcionários com conhecimento técnico e empréstimos de equipamentos.

A cooperação técnica com fornecedores de insumos - os colorifícios - é a base para o desenvolvimento de produtos, tanto nos aspectos técnicos quanto estéticos.

$\mathrm{Na}$ fase de crescimento a vantagem competitiva crucial foi a capacidade de investimento e crescimento rápido da produção. Isto foi propiciado pela atração para o APL das empresas correlatas, principalmente os fornecedores de equipamentos e colorifícios.

No APL de Santa Gertrudes houve atuação relevante, na década de 90, de órgãos de apoio técnico como o IPT; CCB, com a instalação de um laboratório de qualidade e inovação; Departamento de Materiais da Universidade Federal de São Carlos e o Departamento de Geologia da UNESP de Rio Claro, corroborando a hipótese de atração de elos a montante, nesta fase evolutiva.

\subsubsection{Maturidade de Santa Gertrudes}

No final da década de 90 e início do ano de 2000, o APL, aparentemente, passa a enfrentar sua maturidade. As características observáveis guardam caráter de transição entre uma fase e outra.

A produção já atinge todo o mercado brasileiro, apesar das vendas se concentrarem em São Paulo e Rio de Janeiro. Simultaneamente, devido ao próprio crescimento da produção de Santa Gertrudes, os mercados se tornam saturados de produtos de baixo valor agregado. O elo da distribuição passa diminuir as margens dos fabricantes. A vantagem de custo detida por Santa Gertrudes já não lhe confere maior rentabilidade. As empresas passam então a competir qualitativamente em serviços agregados. Essa competição reduz as economias de escala, visto que os custos de transportes e distribuição passam a crescer comparativamente aos custos de produção. 
A maior competição por mercados entre as empresas do APL inibe os processos de cooperação técnica, tanto vertical quanto horizontal. A redução das margens das empresas cerâmicas aumenta os riscos do negócio, inibindo o crédito que os fornecedores de equipamentos disponibilizavam aos ceramistas. Os colorifícios também passam a sofrer quedas de margem como reflexo da compressão das margens dos ceramistas. Os serviços agregados pelos colorifícios, caracterizados como cooperação técnica, tornam-se relativamente custosos para estes, tendendo a levá-los à redução deste tipo de atuação.

A exportação também se inicia de forma expressiva nesse período, com o início de atuação das associações empresarias no apoio a participação das empresas em feiras internacionais.

\subsubsection{Pós-maturidade}

Na pós-maturidade acredita-se que ocorra a dispersão ou surgimento de novos APL's. A redução na centralidade de Santa Gertrudes pode ser dbservada pela instalação de plantas das empresas do APL em outras localidades, como Bahia. A sobrevida de Santa Gertrudes exigirá delas o reconhecimento de que suas vantagens originais não mais se fazem presentes com a mesma intensidade. Há que se intensificar a cooperação na comercialização, o investimento em qualidade, design, marcas e distribuição. O APL não deixará propriamente de existir, mas a sua competitividade será cada vez menos dependente da proximidade geográfica das empresas. 


\section{CONCLUSÕES E RECOMENDAÇÕES}

O objetivo deste trabalho foi compreender a interação entre concentração geográfica de empresas, competitividade e tecnologia no Arranjo Produtivo de Santa Gertrudes.

O que motivou o trabalho foi a observação de que esse arranjo apresentou crescimento extraordinário na década de 90, passando a ser o principal pólo produtor de cerâmica de revestimento (38\% do volume produção brasileira em 2001), ultrapassando a antiga capital da cerâmica brasileira, o APL de Criciúma (16\% do volume de produção brasileira em 2001).

Propôs-se, então, um modelo para explicar o surgimento e desenvolvimento dos APL's, procurando validá-lo para o caso de Santa Gertrudes. A principal hipótese do modelo aqui desenvolvido é de que uma inovação revolucionária (radical no processo), combinada com condições locais específicas, pode originar novo APL, caso seja estabelecido paradigma de processo alternativo com economias de escala superiores às existentes. Observa-se que existe um padrão de evolução dos APL's, desde o nascimento, passando pelas fases embrionária, crescimento, maturidade e pós-maturidade ou declínio. À medida que o APL evolui, em cada uma das fases, os padrões competitivos se alteram, assim como a importância das economias de escala iniciais. A preocupação com as economias de escala e suas implicações no sistema produtivo das empresas induz à necessidade de traduzir e investigar as trajetórias tecnológicas e compreender seu papel nas diversas fases de evolução dos APL's.

Na confrontação do modelo ao caso de Santa Gertrudes constatou-se que este APL, teve padrão de evolução consistente com o modelo desenvolvido. Atualmente, o arranjo produtivo de Santa Gertrudes está atravessando o turning point do crescimento para a maturidade.

A origem do arranjo remonta ao início dos anos 70, quando antigos produtores de cerâmica estrutural passaram a produzir cerâmica de revestimento utilizando a moagem via seca, paradigma de produção alternativo à via úmida, majoritariamente utilizado na Itália, Espanha e Santa Catarina. A moagem via seca implantada em Santa Gertrudes, possibilitou significativas economias de escala em relação à via úmida, reduzindo uso de energia e estoques de matérias-primas. A argila presente na região, até então, se mostrava inadequada aos processos de moagem. Foram os 
empresários e técnicos brasileiros, com colaboração da indústria de equipamentos, que conseguiram adaptar o processo via seca às condições da argila local. Para as demais fases do processo produtivo, como a queima, os empresários locais utilizaram equipamentos obsoletos, ou adaptaram os equipamentos anteriormente usados na produção de cerâmica estrutural. A existência anterior de um setor correlato foi fundamental, uma vez que os empresários e a mão-de-obra conheciam fases do processo, como a mineração, e puderam utilizar equipamentos da antiga indústria de telhas. Com essa inovação e esse processo produtivo, os empresários de Santa Gertrudes conseguiam produzir uma placa extremamente barata e com pouca variedade de tamanhos e cores. Isso possibilitou a conquista de parcelas significativas do mercado, antes dominado pelo pólo de Criciúma, em Santa Catarina. Na fase embrionária, a competição em Santa Gertrudes ocorria exclusivamente por custo, sem que houvesse qualquer preocupação com a qualidade. A cooperação técnica com a indústria de equipamentos era incipiente. A cooperação entre as próprias empresas cerâmicas ocorria de maneira informal e aberta, centrada nas informações sobre as experiências de cada empresário nas adaptações da matériaprima e processo produtivo baseada principalmente nas relações familiares.

No início dos anos 80, o APL entra na fase de crescimento a partir da adoção de uma série de inovações disponibilizadas pela indústria de equipamentos que permitiu que as economias de escala fossem ampliadas, melhorando a qualidade do produto. Algumas inovações estavam disponíveis para todas as empresas cerâmicas, como o processo monoqueima rápida, as esteiras rolantes e os processos de mecanização da escolha e embalagem do produto final. Esses novos equipamentos eram geradores de grandes economias de escala, poupadores de mão-de-obra, energia e principalmente, tempo de ciclo. Também foram introduzidas inovações que melhoravam o processo de moagem via seca, reduzindo e uniformizando a granulometria da massa.

No Brasil, as empresas de Santa Gertrudes que estavam capitalizadas em comparação com as de Santa Catarina, conseguiram comprar equipamentos modernos, com recursos próprios ou financiamentos obtidos junto aos próprios fabricantes de equipamentos. É nesse período que o APL de Santa Gertrudes apresenta crescimento extraordinário, com melhora considerável na qualidade do produto. São atraídos os fornecedores de esmaltes - colorifícios, que se tornaram responsáveis pelo 
fornecimento do design. A cooperação com os fornecedores de equipamentos é intensa, assim como com os colorifícios. O padrão competitivo ainda é baseado no custo, surgindo a preocupação com a qualidade do produto. Apesar disso, os produtos de Santa Gertrudes não são diferenciados entre si, podendo ser considerados commodities. Como o mercado está em expansão, a governança da cadeia fica com as empresas cerâmicas e elos a montante, como os produtores de equipamentos e colorifícios.

No final da década de 90 e início dos anos 2000 são dbservados os primeiros sinais de maturidade do pólo. O mercado interno começa sinalizar estagnação, apresentando períodos eventuais de retração da demanda, como o que foi observado no período de racionamento de energia no ano de 2001, quando o mercado de habitação, principal cliente da indústria cerâmica, teve queda na demanda. Nessa época, houve retração da produção. A partir de 2002, observa-se novo movimento de expansão da capacidade produtiva, com as novas linhas que deverão entrar em funcionamento até o início do ano 2004.

O mercado externo começa a assumir papel de maior relevância, com aumento das exportações principalmente para países mais próximos, e Mercosul. Essa ampliação da área de mercado atingida é outra evidência da entrada na fase de maturidade.

Outra evidência da tendência à maturidade (ou pós-maturidade) é a instalação das primeiras filiais de empresas de Santa Gertrudes no Recôncavo Baiano, pois com os incentivos do governo local, a estratégia de produção em larga escala pode ser mantida.

A percepção geral dos empresários, contudo é que a redução de suas margens é fenômeno passageiro. A reação das empresas tem sido de persistência nas estratégias da fase de crescimento: ampliação da capacidade produtiva na busca de redução de custos. A atuação de cada empresa tem, portanto, gerado resultados contraproducentes, já que o crescimento da produção vem a contribuir com nova rodada de compressão de margens. Na fase de maturidade as competências em gestão do negócio e marketing seriam os principais fundamentos competitivos das empresas. A partir dessa visão, pode-se vislumbrar recomendações voltadas à 
redefinição das estratégias de marketing das indústrias, per si, e do cluster, em seu conjunto.

Atualmente, a governança da cadeia de produção cerâmica reside na distribuição e vendas. Para obter-se parte do excedente que hoje fica nesse elo, é necessário trazer a governança de volta às empresas cerâmicas. Historicamente, o que se observa é que isso pode ocorrer de duas formas: a partir de grandes empresas verticalizadas (Criciúma) ou a partir de médias e pequenas empresas que atuam de forma coordenada (Sassuollo). No caso de Santa Gertrudes, onde há relativa homogeneidade no tamanho das empresas, sem predomínio de nenhuma grande, é necessário que haja uma ou mais entidades que coordenem a cadeia de valor. Esses elos estão no chamado meso-espaço, onde localizam-se as entidades de classe, pesquisa, treinamento e certificação. Dessa forma, é necessário que se reforce o meso-espaço para que haja entidades fortes o suficiente para definir a governança da cadeia.

A cooperação com elos a montante, como mineração, colorifícios e produtores de equipamentos, deve mudar suas características. As relações com esses elos ainda são baseadas em minimização dos custos. Atualmente, com a política de redução de custos, a qualidade da matéria-prima está em segundo plano. Estratégia de agregação de valor no longo prazo deve considerar a importância da garantia de fornecimento de matéria-prima adequada. Para tanto, a capacitação tecnológica tanto na mineração, como no beneficiamento deve ser ampliada.

A manutenção da atividade para o fornecimento de matéria-prima para a produção de placas cerâmicas em médio prazo está comprometida, pois boa parte das minerações está com regularização precária e se a extração parar, o setor pode entrar em colapso. É necessário programa de regularização dos empreendimentos atuais e definição de zoneamentos mínero-ambientais.

A maioria das necessidades para o aperfeiçoamento da produção da argila tem tecnologia conhecida e consistem em prática habitual em empreendimentos de outros bens minerais. São necessários, principalmente, investimentos na fase prélavra que permitam o conhecimento regional e local das matérias-primas, para então aplicar o planejamento e método de lavra mais adequado, que assegure minério em 
conformidade e a custos competitivos. Na etapa da lavra propriamente dita, bem como nas etapas de pré-preparação e moagem da matéria-prima, as empresas encontram-se bem equipadas.

A cooperação com os colorifícios é intensa, mas totalmente baseada na estratégia de redução de custos. A atividade de design é considerada pela maioria das empresas cerâmicas custo adicional, uma vez que os colorifícios oferecem o serviço gratuitamente. ${ }^{1}$ Essa prática transformou a cerâmica de Santa Gertrudes em commodity, sem diferenciação entre os fabricantes, com design sempre atrasado em relação às principais marcas nacionais e internacionais. A cerâmica padronizada é produto que deve compor o portfólio das empresas para sustentar o negócio, mas não deve constituir-se na única opção. Para manter a competitividade das empresas em longo prazo é necessário desenvolver design diferenciado, típico de Santa Gertrudes.

O desenvolvimento de design tecnologicamente mais sofisticado, com mais serigrafias e camadas de esmalte também é desejável. Na Itália as empresas utilizam até 18 aplicações de serigrafia em uma peça. A média em Santa Gertrudes é 4.

Para tal, seria adequado que as empresas contassem com equipes de design, que poderiam ser terceirizadas, assessorando o desenvolvimento de novos produtos com garantia de exclusividade e que conferissem identidade própria ao produto de cada empresa. A cooperação com os produtores de equipamentos foi a principal responsável pelas inovações incrementais e pelos grandes ganhos de escala obtidos nas fases anteriores. Nessa nova fase observa-se que parte dos investimentos das empresas foi feita para aquisição de equipamentos destinados a melhorar e otimizar o processo de esmaltação, responsável pelo acabamento do produto. Persistem ainda as compras de novas linhas que objetivam aumentar as economias de escala.

Destacam-se as dificuldades de interação do APL de Santa Gertrudes com o sistema de C\&T. No caso específico do IPT, que possui capacitação em várias fases do processo produtivo, desde a mineração até o assentamento, a interação com o pólo é insatisfatória em algumas áreas ou inexistente em outras. A mineração e o processo de preparação da massa são objetos de propostas de atuação da Divisão de Geologia junto às empresas locais, como, por exemplo, projetos de melhoria na dispersão do 
pó na fase de mistura. As empresas enxergam a atuação do IPT como muito acadêmica, custosa e sem resultados de curto prazo. Mesmo que o projeto não tenha custos diretos para as empresas, elas consideram que o tempo necessário para realizar experimentações na linha é oneroso, pois pode comprometer horas de produção. Capacitações de IPT em outros elos da cadeia, como no assentamento, não são sequer conhecidas no APL.

O CCB tem atuação mais efetiva no local; tanto na certificação, no apoio técnico e, principalmente, no assentamento. Sua atuação está de acordo com as necessidades da nova fase de maturidade do APL.

A distribuição e comercialização são fundamentais nessa nova fase do APL. Atualmente, uma das dificuldades apontadas pelos distribuidores é a pouca profissionalização das equipes de vendas das empresas cerâmicas, uma vez que a responsabilidade maior pela venda fica com os representantes, que buscam benefícios para o próprio distribuidor em detrimento da empresa cerâmica. É recomendável que as empresas cerâmicas realizem investimentos em treinamento de profissionais que representem verdadeiramente os interesses das empresas produtoras de cerâmica.

Outro investimento fundamental é o controle da logística de distribuição. Pode-se buscar esse controle como foi feito pelas empresas de Sassuollo na Itália, onde uma empresa foi criada para coordenar o sistema de transporte e entrega, tanto de matériaprima quanto de produto acabado. As vantagens são inúmeras para as empresas, revendedores e consumidores, em termos da redução no volume de estoques, ampliação do leque de produtos em exposição, redução dos prazos e entrega ao consumidor e maior homogeneidade dos lotes comercializados. Esse último item, frise-se, é fundamental para a uniformidade no assentamento e performance geral do revestimento.

A preocupação com o assentamento, que fica com grande parte do valor agregado do produto acabado, também é necessária nessa nova fase do APL. Além de o esforço até aqui feito para treinar assentadores, é preciso incorporar estes profissionais em uma rede de serviços ligada à indústria cerâmica, estimulando o consumidor a

\footnotetext{
${ }^{1}$ Na verdade, o custo do design está embutido no preço dos esmaltes.
} 
contratar serviços credenciados. Nos produtos concorrentes, como os carpetes, a colocação é feita com vinculação da garantia do produto com a contratação de profissionais autorizados ou com a compra do produto juntamente com o serviço de instalação. É preciso normatizar as relações comerciais entre assentadores e outros atores do negócio cerâmico: indústria, revendedores e consumidores. Atualmente, mesmo os assentadores treinados e recomendados pela ANFACER têm total liberdade para a definição tanto de procedimentos técnicos quanto de preços e prazos de entrega. Além disso, não há qualquer vínculo ou co-responsabilidade da indústria ou de revendedores para com os assentadores.

Além de assentadores, há outros profissionais fundamentais na venda da cerâmica, arquitetos, engenheiros e vendedores. Com relação a esses profissionais, muito pouco tem sido feito em treinamento, divulgação e promoção da cerâmica, mormente a de Santa Gertrudes. Aos arquitetos, em especial, deve ser estimulada a aplicação de cerâmicas em seus projetos. A constituição de uma premiação anual aos projetos executados que apliquem cerâmica seria uma forma de estímulo aos arquitetos e de divulgação da cerâmica.

As mesmas preocupações com o marketing nacional devem valer para a conquista de mercados internacionais. Acrescente-se que nos países desenvolvidos há estruturação mais consistente dos mercados. Assim é que se encontram, naqueles países, redes com grande número de lojas de revendas, cobrindo grandes territórios. Encontram-se empresas especializadas em logística que garantem a entrega de produtos em prazos bastante curtos. É possível, também, procurar estreitar relações e propor parcerias com sindicatos e associações de assentadores no exterior.

As ações aqui propostas dificilmente poderão ser desencadeadas por cada empresa. $\mathrm{O}$ reforço dos organismos de apoio e cooperação interindustrial se faz necessário. Observa-se que, nesse aspecto, existem entidades de classe, com muito maior volume de recursos, nos demais pólos bem sucedidos, a exemplo da ASCER e ASSOPIASTRELLE.. O formato do sistema de sustentação financeira dessas entidades é crucial para a sua efetividade na assistência aos interesses da indústria. No caso de Santa Gertrudes, as instituições que atuam localmente, como a ASPACER e o Sindicato das Indústrias da Construção e do Mobiliário de Santa 
Gertrudes, parecem ainda não ser valorizadas devidamente pelos empresários do setor. Um, modelo de sustentação financeira que tivesse como base o recolhimento sobre o volume de vendas global poderia ser o primeiro passo para viabilizar grandes projetos mobilizadores e maior assistência às empresas locais.

Um importante aspecto da concentração geográfica de empresas, o capital social, não foi tratado na validação do modelo por dificuldades de mensuração. Algumas características observadas podem dar pistas do comportamento e da qualidade das interações sociais. A importância da família foi verificada desde as primeiras fases do APL de Santa Gertrudes. Até atualmente, as diretorias das empresas sempre contam com familiares na sua composição. A facilidade da cooperação horizontal bilateral entre empresas do mesmo grupo familiar, como empréstimo de funcionários e financiamentos também foi constatada.

Um aspecto do capital social que pode ser observado a partir da certificação é a confiança. No caso de Santa Gertrudes, a confiança originada na certificação aparentemente é baixa, dado que o grau de certificação dos produtos do APL é de apenas $12 \%$ das empresas. Esse índice é baixo quando se vislumbra a atuação no mercado externo.

Programas de qualidade e fornecimento assegurado podem reduzir custos e riscos das empresas mineradoras e dos colorifícios. Esses últimos, responsáveis pelo design das peças disponibilizam o desenho, mas, as vezes, o esmalte é comprado do concorrente. Os programas de qualidade assegurada podem caracterizar, formalmente, a cooperação com elos a jusante, aumentando o grau de confiança no sistema. A cooperação, neste trabalho considerada como vantagem competitiva interna às empresas, é bastante favorecida por sistemas produtivos com altos graus de confiança.

No Brasil, a observação de vários casos de sucesso semelhantes ao de Santa Gertrudes gerou tendência para a elaboração de políticas para estímulo ou mesmo criação de Arranjos Produtivos Locais. Como exemplo, destacam-se os programas de apoio e financiamento do BNDES (Banco Nacional de Desenvolvimento Econômico e Social), FINEP (Financiadora de Estudos e Projetos do MCT - Ministério de 
Ciência e Tecnologia) e SEBRAE (Serviço Brasileiro de Apoio às Micro e Pequenas Empresas).

Os principais pontos apresentados nas propostas de políticas públicas dessas organizações são: a) a necessidade de examinar não apenas o segmento principal, mas os encadeamentos a montante e a jusante e verificar onde está a governança; b) o apoio à inovação para a competitividade das empresas; c) o incentivo à cooperação para resolver problemas comuns; e d) o fortalecimento das instituições e da sociedade, o chamado capital social.

Essa difusão do modelo APL pode criar distorções quando ele é visto como a única forma de organização e crescimento de setores econômicos. Os programas e políticas focalizam ações que podem não ser as mais adequadas para as localidades, pois estas políticas devem estar ajustadas ao grau de maturidade dos APL's. Isto porque, o papel da inovação, da cooperação e do capital social não devem ser analisados de forma estática. A busca da inovação deve ser orientada pelas características evolutivas do APL. Quando nas primeiras fases, a inovação busca adaptar processos e ampliar as economias de escala. Quando o APL entra na fase de maturidade, as inovações devem buscar qualidade e diversificação.

A cooperação também apresenta comportamento variável. Na fase embrionária a cooperação informal é facilitada. Nas fases mais avançadas, ela deve ser frmalizada. A cooperação horizontal de caráter técnico é mais freqüente na fase embrionária. A cooperação vertical com elos à montante deve ser buscada, mormente, na fase de crescimento. Na fase de maturidade, a cooperação deve ser intensificada nos elos a jusante, como a distribuição e comercialização. No caso de Santa Gertrudes, o assentamento é fase fundamental, que agrega grande parte do valor da cerâmica. A cooperação com a construção civil, responsável pelo assentamento atual é incipiente ou inexistente, deveria ser priorizada.

As economias de escala, que no modelo aqui proposto são consideradas responsáveis pela origem dos agrupamentos são tratadas apenas por Krugman, e não são consideradas nas propostas de políticas públicas. A relação entre inovação revolucionária, trajetórias tecnológicas e economias de escala não são abordadas em 
nenhum modelo encontrado na literatura, sendo, esta, uma das contribuições originais deste trabalho.

No caso de Santa Gertrudes observa-se que, que apesar do APL estar entrando na fase de maturidade, a maioria das empresas persiste em investir nas mesmas vantagens competitivas que resultaram bem sucedidas na fase de crescimento. A estratégia de competição por custos e ampliação das economias não é sustentável no longo prazo, pois, na fase de maturidade, exige-se novas estratégias competitivas. Recomenda-se que o APL de Santa Gertrudes promova o uso da cerâmica de forma valorizada, agregando ao produto qualidade, design e a assistência aos revendedores e consumidores. De fato, a governança da cadeia que hoje está na distribuição, só será retomada pelas empresas a partir de mudanças estratégicas.

O governo deve ter papel fundamental na redefinição da estratégia do aglomerado de Santa Gertrudes. O apoio à exportação, a coordenação das instituições de pesquisa e centros de treinamento, a garantia de dados estatísticos confiáveis, o aprimoramento de sistemas de financiamento estão entre as principais demandas do setor privado para o governo.

A coordenação da ação das instituições de pesquisa é fundamental e deve ser assumida por instâncias governamentais hierarquicamente superiores, como a SCTDET (Secretaria de Ciência, Tecnologia, Desenvolvimento e Turismo). É importante ressaltar que as ações envolvendo as instituições de pesquisa devem contar também com o apoio dos órgãos de fomento. Existe significativo número de instituições técnicas e de pesquisa, com capacidade instalada razoável, porém trabalhando de forma desarticulada e sem soma de esforços.

A conquista de mercados externos requer esforço de comercialização coordenado, que passa pela propaganda maciça e pela confiança dos clientes potenciais na qualidade dos nossos produtos. É urgente e altamente recomendável o envolvimento do Governo do Estado de São Paulo em amplo esforço de promoção das exportações dos produtos do APL de Santa Gertrudes, que já gozam de significativa vantagem em custos em comparação com os produtos do sul.

Sabe-se que os revestimentos cerâmicos têm propriedades importantes com relação à higiene, proteção contra a corrosão e umidade. Algumas cidades litorâneas 
brasileiras, por exemplo, têm a aplicação de revestimentos cerâmicos como obrigatório, em lei, para fachadas de edifícios próximos ao mar. Hospitais, cozinhas industriais, laboratórios farmacêuticos entre outros, já adotam revestimentos cerâmicos de forma corrente. Em alguns casos, essas aplicações também poderiam ser objeto de obrigatoriedade legal. É preciso atuação das associações de classe junto aos órgãos competentes, legislativo e associações dos setores eventualmente afetados.

Outras sugestões levantadas nas entrevistas com as empresas para a atuação do governo foram: subsidiar a participação de produtores junto a feiras internacionais; liberação de financiamento para a construção civil; atuar na redução dos custos portuários e apoiar empresas inovadoras para provocar efeito demonstração, por meio de prêmio ou financiamento subsidiado.

Recomenda-se que as ações dos diferentes elos da cadeia produtiva, inclusive do governo, devem ter como orientação o fato de que o APL de Santa Gertrudes está entrando em nova fase evolutiva. Essa questão não é devidamente compreendida pelos vários atores da cadeia, incluindo os próprios produtores de cerâmica, o que faz com que suas demandas sejam voltadas às reduções de custo. Exemplo é a freqüente demanda dos empresários por diminuição de impostos. Programas para o setor, voltados ao incremento da qualidade e investimentos na distribuição, assentamento e exportações podem até sofrer resistência dos ceramistas, mas seriam mais adequados para a fase evolutiva em que se encontra o APL de Santa Gertrudes.

O APL de Santa Gertrudes apresentou um padrão típico de evolução e não foi necessário a intervenção de políticas públicas para seu sucesso Acredita-se, porém, que o papel das políticas públicas seja o de reverter tendências em APL's que não estejam ajustadas a fase do ciclo evolutivo do mesmo.. No próprio APL de Santa Gertrudes, uma das economias externas que não se desenvolveu a contento foi o fortalecimento de um dos elos a jusante: a mineração. A trajetória deste elo em Santa Gertrudes originou problemas ambientais, criando externalidades negativas ou deseconomias externas.

Como recomendação de futuras investigações propõe-se que o modelo seja verificado em outros APL's, desde setores tradicionais, como calçados, móveis e 
confecções, até setores intensivos em tecnologia, como telecomunicações. O modelo também deve ser verificado para setores de serviços, como turismo e logística.

As características sociais, confiança e papel do governo também são pontos que merecem indicações de estudos futuros. As externalidades negativas, advindas dos congestionamentos provocados pelo adensamento industrial e urbano nos APL's são pontos pouco explorados na literatura e que têm impactos que devem ser estimados.

O conceito de área de influência, originado no modelo proposto por LÖSH, deve ser melhor investigado para compreender a dinâmica de nascimento e dispersão de APL's dentro de um determinado setor. $\mathrm{O}$ que se observou no setor de cerâmica de revestimento é que os APL's atingem determinadas áreas de influência com um produto de baixo custo. Quando entram na fase de maturidade, os produtos precisam agregar valor para atingir mercados mais distantes, possibilitando o nascimento de novos APL's.

Os conceitos de custos de transação e especificidade de ativos, adotados por WILLIANSON (1987) e que não foram abordados neste trabalho, podem ajudar a compreender melhor a relação entre custos fixos e custos variáveis, sendo, portanto, outra linha interessante de pesquisas futuras. 


\section{BIBLIOGRAFIA}

ABERNATHY, W.J.; CLARK, K.B. Innovation: mapping the winds of creative destruction. TUSMAN, M.L.; MOORE, W.L. (Orgs.) Readings in the management of innovation. 2.ed. Cambridge: Ballinger Pub., 1988. p.55-78.

ABRAMOVAY, R. O capital social dos territórios: repensando o desenvolvimento rural. In: SEMINÁRIO SOBE REFORMA AGRÁRIA E DESENVOLVIMENTO SUSTENTÁVEL, 1998, Fortaleza, CE. Disponível em: < http://www.dataterra.org.br/Semce/abramovay.htm> Acesso em: 23 ago. 2002.

ALARCÓN, O.E. et al. Relatório do grupo design. In: Projeto Plataforma. São Paulo: Centro Cerâmico do Brasil/ Instituto de Pesquisas Energéticas Nuclear, [199_].

ALBU, M. Technological learning and innovation in industrial clusters in the south. Sussex: University of Sussex/ SPRU, 1997. 49p. (Eletronic Working Papers Series 7)

AMARAL FILHO, J. A endogeneização no desenvolvimento econômico regional. Fortaleza: UFC, [199_] 15p.

AMATO NETO, J. Reestruturação industrial, terceirização e redes de subcontratação. Revista de Administração de Empresas, São Paulo, v.35, n.2, p.3342, mar./abr. 1995.

ARAÚJO, A.;. ROMACHELLI, J.C.; MARTINS, M. Análise crítica do setor de revestimentos cerâmicos no Brasil parte I: histórico recente. Cerâmica Industrial, São Paulo, v.6, n.4, p.29-34, jul./ago. 2001.

\section{ASOCIACIÓN ESPAÑOLA DE FABRICANTES DE AZULEJOS Y}

PAVIMENTOS CERÁMICOS. Informe Los sectores español y mundial de fabricantes de baldosas cerámicas 2001. Castellón: ASCER, 2002. Disponível em: <http://www.ascer.es> Acesso em: 07 maio 2002. 
ASSOCIAÇÃO BRASILEIRA DE CERÂMICA - ABCERAM. Apresenta homepage da Instituição. Disponível em: <http://www.abceram.org.br/> Acesso em: 16 abr. 2001.

ASSOCIAÇÃO BRASILEIRA DE CERÂMICA - ABCERAM. Apresenta informações sobre materiais de revestimento. Disponível em:

<http://www.abceram.org.br/cerabrasil/panoramas/revestimentos.htm> Acesso em: 13 abr. 2001.

ASSOCIAÇÃO NACIONAL DOS FABRICANTES DE CERÂMICA PARA REVESTIMENTO. Panorama da industria cerâmica brasileira. São Paulo: ANFACER, 1999.

ASSOCIAÇÃO NACIONAL DOS FABRICANTES DE CERÂMICA PARA REVESTIMENTO. ANFACER, apoiando a cerâmica do Brasil. São Paulo: ANFACER, 2000.

ASSOCIAÇÃO NACIONAL DOS FABRICANTES DE CERÂMICA PARA REVESTIMENTO- ANFACER. Apresenta banco de dados de notícias. Disponível em: 〈http://www.anfacer.org.br/portugues/xnoticias.html > Acesso em: 16 abr. 2001.

ASSOCIAÇÃO NACIONAL DOS FABRICANTES DE CERÂMICA PARA REVESTIMENTO - ANFACER. Apresenta homepage da instituição. Disponível em: <http://www.anfacer.org.br/> Acesso em: 16 abr. 2001.

AUDRETSCH, D.B.; FELDMAN, M.P. Innovative clusters and the industry life cycle. Review of Industrial Organization, v.11, n.2, p.253-273, Apr. 1996.

AZEVEDO, P.F. Organização industrial. In: MONTORO FILHO, A.F. et al. (orgs) Manual de economia. 3.ed. São Paulo : Saraiva, 1998. cap.8; p.195-222.

BAGNASCO, A. The theory of development and the italian case. Disponível em: <http://www.vanzolini.org.br/seminarioousp/1.jpg> Acesso em: 5 jul. 2000.

BARRACUHY, J.L. Cerâmica: cores, texturas e formatos novos. Arquitetura \& Construção, p.82-89, nov. 2000. 
BELL, M.; ALBU, M. Knowledge systems and technological dynamism in industrial clusters in developing countries. World Development, v.27, n.9, p.171534, Sept. 1999.

BELTRAME, E. Tecnologia e padrão de concorrência da indústria de revestimentos cerâmicos de Santa Catarina. Florianópolis, 1998. 130p. Dissertação (Mestrado) Departamento de Ciências Econômicas; Universidade Federal de Santa Catarina.

BERNARDO, M.S. Distritos industriais: clusters. Ribeirão Preto: FEARP-USP, 1999. Disponivel em:

<http://www.fearp.usp.br/afearp/estrutura/comissoes/pesq/Textos/wpc3.pdf $>$ Acesso em: 13 dez. 2002.

BERNARDO, M.S.; SILVA, A.C.; SATO, S. Distritos industriais - clusters.

Ribeirão Preto, USP/FEA-RP, 1999. 29p. (Texto para Discussão 3) Disponível em: <http://www.fearp.usp.br/fearpinfo/c3.pdf> Acesso em: 25 out. 2001.

BERTO, R.M.V.S.; NAKANO, D.N. Metodologia da pesquisa e a engenharia de produção. In: ENCONTRO NACIONAL DE ENGENHARIA DE PRODUÇÃO, 18., 1998, Rio de Janeiro, RJ. Anais...Rio de Janeiro: ABEPRO, 1998. 1 CD.

BNDES e Banco do Brasil vão apoiar pequenas empresas integrantes de Arranjos Produtivos Locais. Disponível em: 〈http://www.bndes.gov.br/noticias/not620.asp $>$ Acesso em: 29 maio 2003.

BOSCHI, A.O.; MENEGAZZO, A.P.M. Relatório do grupo desenvolvimento de massas e produtos cerâmicos. In: Projeto Plataforma. São Paulo: Centro Cerâmico do Brasil/ Instituto de Pesquisas Energéticas Nuclear, [199_].

BRUSCO, S. The Emilian model: productive decentralisation and social integration. Cambridge Journal of Economics, v.6, n.2, p.167-184, June 1982.

CAMPOS, R. Reflexões sobre o desenvolvimento. Folha de São Paulo, São Paulo, 09 maio 1999. p.4 
CAMPOS, R.R.; NICOLAU, J.A.; CÁRIO, S.A.F. Clusters e capacitação tecnológica: a experiência na indústria cerâmica de revestimento de Santa Catarina. In: ENCONTRO DE ECONOMIA DA REGIÃO SUL, 2. Curitiba, 1999. Anais... Curitiba: UFPR/ANPEC, 1999. 1 CD

CAMPOS, R.R.; NICOLAU, J.A.; CÁRIO, S.A.F. O cluster da indústria cerâmica de revestimento em Santa Catarina: um caso de sistema local de inovação - versão preliminar. Mangaratiba: UFSC/UFRJ, 1998. 70p.

CASSIOLATO, J.E.; LASTRES, H.M.M. Arranjos e sistemas produtivos locais na indústria brasileira. Disponível em: <http://www.mdic.gov.br/tecnologia/revistas/artigos/200104rj/art05CassiolatoLastres .PDF> Acesso em: 26 maio 2003.

CASTRO, A.B. A economia política do desenvolvimento regional sustentável. S.n.t.

CENTRO CERÂMICO DO BRASIL. Certificação: certificados de produto vigentes em conformidade com a norma NBR 13818. Disponível em: < http://www.ccb.org.br/produtos_porfabricante.htm> Acesso em: 26 maio 2003.

CENTRO CERÂMICO DO BRASIL. Certificação: Certificados ISO 9000. Disponível em: 〈http://www.ccb.org.br/certificados_iso9000.htm> Acesso em: 26 maio 2003.

CERAMIC WORLD REVIEW, Modena, v.10, n.35, Jan./Feb. 2000.

CERAMIC WORLD REVIEW, Modena, v.10, n.36, Mar/May. 2000.

CERAMIC WORLD REVIEW, Modena, v.10, n.38 Aug./Sept. 2000.

CLEMENT, A.; HIGACHI, H.Y. Economia e desenvolvimento regional. São Paulo: Atlas, 2000. 260p.

CLUSTERS de Minas: relatório. Gazeta Mercantil, São Paulo, 4 set. 2001. p.A8-9 
CONEJOS, J. et al. Strategic change and clusters in Catalonia. Disponível em: <http://www.clustercom.com/book.htm> Acesso em: 28 jun. 2001.

COURLET, C. Novas dinâmicas de desenvolvimento e sistemas industriais localizados (SIL) Ensaios FEE, Porto Alegre, v.14, n.1, p.9-25, 1993.

DALUM, B.; PEDERSEN, C.Ø.R.; E VILLUMSEN, G. Technological life cycles: regional clusters facing disruption. Danish Research Unit for Industrial Dynamics Druid, 2002. (Working Paper 2)

DESIGN BELAS ARTES, São Paulo, v.6, n.7, fev. 2000.

DINIZ, C.C. O papel das inovações e das instituições no desenvolvimento local. Belo Horizonte: UFMG-CEDEPLAR, [200_].

ECO, H. Livro: como se faz uma tese - "como se faz uma tesi di laurea". 14.ed. São Paulo: Perspectiva, 1999.

ENRIGHT, M.J. Regional clusters and strategy. Cambridge: Harvard Business School, 1984. 30p.

FERRAZ, G. Cadeia: cerâmica. In: COUTINHO, L.G. et al. (Coord.) Estudo da competitividadade de cadeias integradas no Brasil: impactos das zonas de livre comércio. Campinas: UNICAMP-IE-NEIT/ MDIC/ MCT/FINEP, 2002. 60p. (Nota Técnica Final)

FERREIRA, M.F.S.; LEMOS, M.B. Localização industrial e fatos estilizados da nova reconfiguração espacial do nordeste. Disponível em: <http://www.anpec.org.br/regional_fortaleza/artigos8.html> Acesso em: 29 jun. 2001.

FUKUYAMA, F. Social capital. In: HARRISON, L.E.; HUNTINGTON, S.P. (ed.)

Culture matters. New York: Perseus Books, 2000. Cap. 8; p.98-111.

FURTADO, J. Limites e possibilidades do Brasil nas configurações produtivas internacionalizadas: uma análise apoiada em diversas cadeias. In: SEMINÁRIO 
CADEIAS PRODUTIVAS GLOBAIS: DESAFIOS PARA O BRASIL, 2000.

UNESP Disponível em: 〈http://www.geein.hgp.com.br> Acesso em: 01 ago. 2000.

GALVÃO, O.J.A. Clusters e distritos industriais: estudos de caso em paises selecionados e implicações de política. Planejamento e Politicas Públicas, Rio de Janeiro, n.21, p.3-49, 2000.

GAMBULI, P. Tendências mundiais da produção de revestimentos cerâmicos. Cerâmica Industrial, v.6, n.6, p.7-10, nov./dez. 2001.

GARCIA, R. As economias externas como fonte de vantagens competitivas dos produtores em aglomerações de empresas. Disponível em:

<http://www.prd.usp.br/redecoop/SEP\%202002\%20Renato\%20Garcia.pdf > Acesso em: 07 out. 2002.

GARCIA, R.C. Importância da dimensão local da inovação e a formação de clusters em setores de alta tecnologia. Ensaios FEE, Porto Alegre, v.22, n.1, p.143-160, 2001.

GAROFOLI, G. O exemplo italiano. Ensaios FEE, Porto Alegre, v.14, n.1, p.49-75, 1993.

GORINI, A.P.F.; CORREA, A.R. Cerâmica para revestimento. BNDES Setorial, Rio de Janeiro, n.10, p.201-252, set. 1999.

GROWTH theory - a historical essay on growth theory. Disponível em: < http://www.econ.jhu.edu/people/fonseca/HET/growth.htm> Acesso: 10 nov. 1999.

GUIA GERAL DE CERÂMICA \& ASSENTAMENTO. São Paulo: Menasce Comunicações, v.8, abr. 2003.

GUISO, L.; SAPIENZA, P.; ZINGALES, L. The role of social capital in financial development. Cambridge: NBER, 2000. 56p. (NBER Working Paper Series). Disponível em: 〈http://www.nber.org/papers/w7563〉 Acesso em: 25 set. 2002. 
HARTMAN, L.M.; SECKLER, D. Toward the application of dynamic growth theory to regions. Journal of Regional Science, v.7, n.2, p.167-73, 1967.

HOBBS, J.E. A transaction cost approach to supply chain management. Supply Chain Management, v.1,n.2, p.15-27, 1996.

HUMPHREY, J.; SCHMITZ, H. A governança em cadeias globais de valor. Disponível em: 〈http://www.nead.gov.br/artigodomes〉 Acesso em: 28 fev. 2002.

HUMPHREY, J.; SCHMITZ, H. Developing country firms in the world economy: governance and upgrading in global value chains. 35p. (INEF Report 61). Disponível em: <http://www.uni-duisburg.de/Institute/INEF/Publikationen/PUBLFRAME-REPORT.HTM> Acesso em: 07 nov. 2002.

HUMPHREY, J.; SCHMITZ, H. Governance in global value chains. Disponível em: 〈http://www.nead.gov.br/artigodomes> Acesso em: 16 jun. 2001.

HUMPHREY, J.; SCHMITZ, H. The Triple C Approach to clusters, with case studies. In: BUILDING A MODERN AND EFFECTIVE BUSINESS DEVELOPMENT SERVICES INDUSTRY IN LATIN AMERICA AND CARIBBEAN, 1999, Rio de Janeiro, RJ. Proceedings...Rio de Janeiro: BID, 1999. Paper 24

HUMPHREY, J.; SCHMITZ, H. The Triple C approach to local industrial policy. World Development, v.24, n.12, p. 1859-1877, Dec.1996.

HUMPHREY, J.; SCHMITZ, H. Trust and inter-firm relations in developing and transition economies. The Journal of Development Studies, v.34, n.4, p.32-61, Apr. 1998.

IGLIORI, D.C. Economia dos clusters industriais e desenvolvimento. São Paulo: Iglu, 2001. 152p.

INSTITUTO BRASILEIRO DE GEOGRAFIA E ESTATISTICA. Classificação de

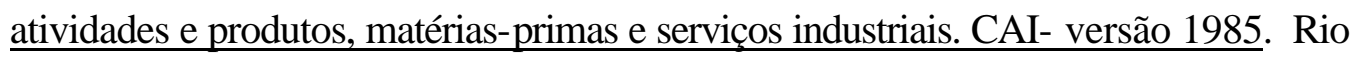
de Janeiro: IBGE, 1991. 
INSTITUTO DE PESQUISAS ECONOMICAS APLICADAS. Temas especiais: rede de políticas industriais descentralizadas. Disponível em: <http://www.ipea.gov.br/polind/ipeaat01.html> Acesso: 22 nov. 1999.

INSTITUTO DE PESQUISAS TECNOLOGICAS. Assessoria técnico-gerencial para implantação de um pólo cerâmico no Estado da Bahia. São Paulo: IPT/DIGEODEES, 2002. 90p. (Relatório Técnico 59.523)

INSTITUTO DE PESQUISAS TECNOLÓGICAS. Programa de atualização tecnológica industrial: cerâmica de revestimento. São Paulo: IPT/DEES, 1988. 44p. INSTITUTO DE PESQUISAS TECNOLÓGICAS. Programa de competitividade das cadeias produtivas paulistas: caso 1: O “Cluster” de cerâmica de Rio Claro. São Paulo: IPT/DEES, 2001. 99p. (Relatório Técnico 54.184)

INVESTNEWS. Apresenta banco de dados para pesquisas de artigos no Jornal A Gazeta Mercantil. Disponível em: 〈http://www1.investnews.com.br/bngm/> Acesso em: 16 abr. 2001.

INVESTNEWS. Apresenta homepage com informações sobre economia e estatísticas de mercados. Disponível em: <http://www.investnews.net/> Acesso em: 16 abr. 2001.

ISAKSEN, A. Regional clusters and competitiveness: the Norwegian case. Oslo: STEP, 1996.

KRUGMAN, P. Location and competition: notes on economic geography. In RUMELT, R.P.; SCHENDEL, D.E.; TEECE, D.J. (Ed.) Fundamental issues in strategy: a research agenda. Boston: Harvard Business School, 1994. Cap. 16, p.463-93.

KRUGMAN, P.R. Development, geography, and economic theory. Cambridge: Mit Press, 1995. 117p.

KRUGMAN, P.R. Geography and trade. Palatino: MIT Press, 1991. 142p. 
KRUGMAN, P.R. The self-organizing economy. Cambridge, Mass.: Blackwell Publishers, 1996. 122p.

KUHN, T. A estrutura das revoluções científicas. [S.l: s.n.], [199-].

LEENDERS, M.R.; ERSKINE, J.A. Case research: the case writing process. 3.ed. London: University of Western Ontario, 1989. 156p.

LEMOS, A.; VIVONA, D. Visão estratégica do setor de revestimentos cerâmicos, mercadológica e tecnológica, em busca da consolidação da competitividade internacional. Cerâmica Industrial, São Paulo, v.2, n.3/4, p.10-18, maio/ago. 1997.

LINS, H. Clusters industriais: uma experiência no Brasil meridional. In:

ENCONTRO DE ECONOMIA DA REGIÃO SUL, 2. Curitiba, 1999. Anais... Curitiba: UFPR/ANPEC, 1999. 1 CD

MAFRA, A.T. Proposta de indicadores de desempenho para a indústria de cerâmica vermelha. Florianópolis: 1999. Dissertação (Mestrado) -Departamento de Engenharia de Produções e Sistemas, Universidade Federal de Santa Catarina. Disponível em: 〈http://www.eps.ufsc.br/disserta99/antero/index.htm> Acesso em: 10 mar. 2000.

MAIOR pólo industrial de cerâmica do país ganha Centro de Inovação Tecnológica. Revista Acomac. Disponível em:

〈http://www.construirparana.com.br/acomac/cursos.htm> Acesso em: 26 maio 2003.

MARKS, C. Centro Cerâmico do Brasil. Info CCB, n.18, set. 2002. Disponível em: <http://www.ccb.org.br/infoccb.html > Acesso em: 14 out.2002.

MARSHALL, A. Princípios de economia. São Paulo: Abril Cultural, 1982. 272p. (Serie os Economistas)

MEYER-STAMER, J. Estimular o crescimento e aumentar a competitividade no Brasil: além da política industrial e da terceirização da culpa. São Paulo: ILDES/ Fundação Friedrich Ebert, 1999. 29p. (Policy Paper 23) 
MEYER-STAMER, J. Estratégias de desenvolvimento local e regional: clusters, politica de localização e competitividade sistêmica. Joinville: Fundação Empreende, 2000. 26p. Disponível em: <http://home.t-online.de/home/meyerstamer/2000/DesLocal.pdf> Acesso em: 5 set. 2001.

MEYER-STAMER, J. What can we learn from the ceramics and textiles/ clothing clusters of Santa Catarina, Brazil. In: BUILDING A MODERN AND EFFECTIVE BUSINESS DEVELOPMENT SERVICES INDUSTRY IN LATIN AMERICA AND CARIBBEAN, 1999, Rio de Janeiro, RJ. Proceedings...Rio de Janeiro: BID, 1999. Paper 26.

MEYER-STAMER, J.; MAGGI, C.; SEIBEL, S. Improving upon nature: patterns of upgrading in ceramic tile clusters in Italy, Spain, and Brazil. Duisburg: IDP/UD, 2000. 62p.

MILONE, P.C. Crescimento e Desenvolvimento econômico: teoria e evidências empíricas. In: MONTORO FILHO, A.F. et al. (Org.) Manual de economia. 3.ed. São Paulo : Saraiva, 1998. cap.22, p.511-30.

MINISTÉRIO DE CIÊNCIA E TECNOLOGIA. Ministro inaugura pólo de inovação em cerâmicas. Noticias CT Brasil, 17 set. 2002. Disponível em: <http://www.mct.gov.br/comunicacao/textos/default.asp > Acesso em: 05 jun. 2003.

\section{MINISTÉRIO DO DESENVOLVIMENTO INDÚSTRIA E COMÉRCIO}

EXTERIOR. Instituto Euvaldo Lodi. O futuro da indústria: oportunidades e desafios a reflexão da universidade. Brasília: MDIC-STI/ IEL/ CNI, 2001. 341p.

MONASTERIO, L.M. Economia institucional e desenvolvimento capital social e crescimento econômico: mecanismos. Disponível em:

<http://www.anpec.org.br/regional_fortaleza/artigo28/artigo28.html > Acesso em: 16 jun.2001.

MONTORO FILHO, A.F. (Org.) et al. Manual de economia. 3. ed. São Paulo: Saraiva, 1998. 653p. 
MOTTA, J.F.M. As matérias-primas cerâmicas e o estudo de três casos de rochas fundentes. Rio Claro: 2000. 208p. Tese (Doutorado) - Instituto de Geociências e Ciências Exatas, Universidade Estadual Paulista. /No prelo/

MOTTA, J.F.M. Novas fontes de matérias-primas para a indústria de cerâmica vermelha. In: ENCONTRO NACIONAL DA ANICER, 31, Palmas, TO. /Trabalho Apresentado/

MUNDO CERÂMICO. São Paulo. Disponível em: <http://www.mundoceramico.com.br/index.htm> Acesso em: 21 mar. 2003.

MYTELKA, L.; FARINELLI, F. Local clusters, innovation systems and sustained competitiveness. Rio de Janeiro: UFRJ, 2000. Disponivel em: $<$ http://www.finep.gov.br/c\&t_no_brasil/estudos/notas_tecnicas/local_clusters_5.pdf > Acesso em: 25 set. 2001.

NADVI, K.; SCHMITZ, H. Industrial clusters in less developed countries: review of experiences and research agenda. Sussex: IDS, 1994. 101p. (Discussion Paper 339).

NASCIMENTO, H.M. Capital social e desenvolvimento sustentável no sertão baiano: a experiência de organização dos pequenos agricultores do Município de Valente. 2000. 119p. Dissertação (Mestrado em Desenvolvimento Econômico) Instituto de Economia, Universidade Estadual de Campinas, Campinas.

NOGUEIRA, E.; ALVES FILHO, A.G.; TORKOMIAN, A.L.V. Empresas de revestimento cerâmico e suas estratégias competitivas e de produção. Gestão \& Produção, São Carlos, v.8, n.1, p.84-99, abr. 2001.

NOTÍCIAS ANFACER. São Paulo: Associação Nacional dos Fabricantes de Cerâmica para Revestimentos, v.3, n.7, dez. 2000.

OLAVE, M.H.L.; AMATO NETO, J. Geração e difusão do conhecimento nos clusters de economias emergentes. In: ENCONTRO NACIONAL DE ENGENHARIA DE PRODUÇÃO, 20., 2000, São Paulo, SP. Anais...São Paulo: ABEPRO, 2000. 1 CD 
PEREIRA, J.C.R. Análise de dados qualitativos: estratégias metodológicas para as Ciências da Saúde, Humanas e Sociais. São Paulo: EDUSP, 1999. 157p.

PERROUX, F. Ensaio sobre a filosofia do novo desenvolvimento. Lisboa: Fundação Calouste Gulbenkian, 1987. 372p.

PERROUX, F.; FRIEDMAN, J.; TINBERGEN, J. Los polos de desarrollo y la planificación nacional, urbana y regional. Buenos Aires: Nueva Visión, 19?. 73p.

PIRES, J.M. Economia regional e urbana. In: MONTORO FILHO, A.F. et al. (Org) Manual de economia. 3. ed. São Paulo : Saraiva, 1998. Cap. 27, p.583-96.

PIVA, M.A.; PACHECO, A.C.B. O que as indústrias de revestimento cerâmico da região de Santa Gertrudes esperam das instituições de ensino, pesquisa e desenvolvimento. Cerâmica Industrial, São Paulo, v.2, n.5/6, p.7-10, set./dez. 1997.

PORTER, M.E. A vantagem competitiva das nações. Rio de Janeiro: Campus, 1993. 897p.

PORTER, M.E. Clusters and the new economics of competition. Harvard Business Review, v.76, n.6, p.77-90, Nov./Dec. 1998.

PORTER, M.E. Competição on competition estratégias competitivas essenciais. Rio de Janeiro: Campus, 1999. 515p.

PORTER, M.E. The competitive advantage of nations. New York: The Free Press, 1990. 855 p.

PORTER, M.E. The competitive advantage of the inner city. Harvard Business Review, v.73, n.3, p.55-71, May/June 1995.

PORTER, M.E. Toward a dynamic theory of strategy. In: RUMELT, R.P.; SCHENDEL, D.E.; TEECE, D.J. (ed.) Fundamental issues in strategy: a research agenda. Boston: Harvard Business School, 1994. Cap. 15, p.423-61.

PUTNAM, R.D. Comunidade e democracia: a experiência da Itália moderna. Rio de Janeiro: FGV, 1996. 260p. 
QUANDT, C. Developing innovation networks for technology-based clusters: the role of information and communication technologies. In: WORKSHOP TECHNOREGIONS: SCIENCE, TECHNOLOGY AND REGIONAL DEVELOPMENT PAST, PRESENT AND FUTURE CHALLENGES, 1998, Rio de Janeiro, RJ. Disponível em: 〈http://technoregions.mse.jhu.edu/Quandt.pdf〉 $>$ Acesso em: 16 set. 1999.

QUANDT, C. The emerging high-technology cluster of Campinas, Brazil. In: INTERNATIONAL DEVELOPMENT RESEARCH CENTRE, TECHNOPOLIS 97 CONFERENCE, Ottawa, Sept. 9-12, 1997.

RABELLOTTI, R. Recovery of a mexican cluster: devaluation bonanza or collective efficiency? Brighton: University of Sussex/ Institute Development Studies, 1998. (Working Paper 71) Disponível em: < http://www.IDS.ac.uk/ids/publicat/wp/WP71.pdf $>$ Acesso em:5 maio 2000.

RIBEIRO, J.A.; QUINTAL, C.A. Considerações logística e estratégicas que levaram a Incefra a optar pela instalação de duas novas empresas na Bahia. Cerâmica Industrial, v.6, n.3, p14-17, maio/jun. 2001.

ROMERO, L.L. et al. Cerâmica para revestimento: relato setorial. Rio de Janeiro: BNDES, 1994. 14p.

ROSENFELD, S.A. Creating smart systems: a guide to cluster strategies in less favoured regions - european union-regional innovation strategies. Carrboro: NC, USA: Regional Technology Strategies, 2002. 35p. Disponível em: $<$ http://europa.eu.int/comm/regional_policy/innovation/pdf/guide_rosenfeld_final.pd f> Acesso em: 10 out. 2002.

RUAS, R.L.; GITAHY, L.; RABELO, F.; ANTUNES, E.D. Inter-firm relations, collective efficiency and employment in two brazilian clusters. Geneva: ILO, 1994. $56 \mathrm{p}$.

SALEJ, S.B. Desenvolvimento regional, cluster e exportação. Gazeta Mercantil, São Paulo, 4 set. 2001. p. A-3. 
SANTOS, A.M.M.M. A indústria de cerâmica para revestimentos. Rio de janeiro: BNDES, 2001. 4p.

SANTOS, A.M.M.M.; GUARNERI, L.S. Características gerais do apoio a arranjos produtivos locais. BNDES Setorial, Rio de Janeiro, n.12, p.195-203, set. 2000.

SCHMITZ, H. Collective efficiency and increasing returns. Brighton: University of Sussex/ Institute Development Studies, 1998. (Working Paper 50) Disponível em: <http://www.IDS.ac.uk/ids/publicat/wp/Wp50.pdf > Acesso em: 5 maio 2000.

SCHMITZ, H. Collective efficiency: growth path for small-scalle industry. The Journal of Development Studies, v.31, n.4, p.529-66, Apr. 1995.

SCHMITZ, H. Conflict mediation with special reference to the sinos valley shoe clusters, Brazil. In: BUILDING A MODERN AND EFFECTIVE BUSINESS DEVELOPMENT SERVICES INDUSTRY IN LATIN AMERICA AND

CARIBBEAN, 1999, Rio de Janeiro, RJ. Proceedings....Rio de Janeiro: BID, 1999. Paper 23.

SCHMITZ, H. From ascribed to earned trust in exporting clusters. International Economics, v.48, n.1, p.139-50, June, 1999.

SCHMITZ, H. Global competition and local cooperation: success and failure in the Sinos Valley, Brazil World Development, v.27, n.9, p.1627-1650, Sept. 1999.

SCHMITZ, H. Small firms and flexible specialisation in LDCs. Sussex: University of Sussex/ Institute of Development Studies, 1989. 34p.

SCHMITZ, H. Small shoemakers and Fordist giants: tale of a supercluster. World Development, v.23, n.1, p.9-28, Jan. 1995.

SCHMITZ, H.; NADVI, K. Clustering and industrialization: introduction. World Development, v.27, n.9, p.1503-1514, Sept. 1999.

SCHUMPETER, J. A. Capitalismo, socialismo e democracia. Rio de Janeiro: Zahar, 1984. Cap.7. 
SEIBEL, S.; MEYER-STAMER, J.; MAGGI, C. Globalização e os desafios para as indústrias italiana, espanhola e brasileira de revestimento cerâmicos. Cerâmica Industrial, v.6, n.6, p.28-38, nov./dez. 2001.

SEZZI, G. Produção e consumo mundial de revestimento cerâmicos. Cerâmica Industrial, v.7, n.5, p.20-28, set./out. 2002.

SILVA, M. A.; DE ABREU, A.; STAMM, H. Discussões em torno do estudo sobre competitividade sistêmica em Santa Catarina. Florianópolis, Joinville: UFSC/UDES, [1999_]

SILVESTRINI, G. Cerâmicas brasileiras ainda longe da concorrência. Gazeta Mercantil, São Paulo, 4 set. 2001. p.A-5

SINDICATO DA INDÚSTRIA DE CERÂMICA - SINDICERAM. Demonstrativo Geral da Produção: capacidade instalada 2002. Disponível em: <http://www.sindiceram.com.br/in52002.htm> Acesso em: 01 jun. 2003.

SMITH, D.M. Neoclassical growth models and regional growth in the U.S. Journal of Regional Science, v.15, n.2, p. 165-84, 1975.

SOUZA, M.C.; GARCIA, R. Sistemas locais de inovação em São Paulo. In: CASSIOLATO, J.E.; LASTRES, H.M.M. Globalização e inovação localizada: experiências de sistemas locais no Mercosul. Brasília: IBICT/MCT, 1999. p.300334.

SOUZA, R.; SILVA, M.A.C.S. Estudo da indústria de cerâmica para revestimentos. Campinas: Unicamp/IE, 1993. 102p. (Projeto: Desenvolvimento Tecnológico e Competitividade da Indústria Brasileira).

THIOLLENT, M. Metodologia da pesquisa-ação. São Paulo: Cortez, 1994. 108p. TIRONI, L.F. Os desafios e oportunidades da indústria brasileira o associativismo competitivo. In: MINISTÉRIO DO DESENVOLVIMENTO INDÚSTRIA E COMÉRCIO EXTERIOR. Instituto Euvaldo Lodi. O futuro da indústria: 
oportunidades e desafios a reflexão da universidade. Brasília: MDIC-STI/ IEL/ CNI, 2001. 341p.

URBAN DEVELOPMENT. Program and project options. More information on cluster and /or sector development. Disponível em:

<http://www.worldbank.org/urban/led/cluster2.html > Acesso em: 11 out. 2002.

UTTERBACK, J.M. Mastering the dynamics of innovation. Boston, Mass.: Harvard Business School Press, 1996. 253p.

UTTERBACK, J.M.; ABERNATHY, W.J. A dynamic model of process and product innovation. Omega The International Journal of Management Science, v.3, n.6, p.639-55, Dec. 1975.

UTTERBACK, J.M.; SUAREZ, F.F. Innovation, competition, and industry structure. Cambridge Mass., Mit, 1990. 56p. (MIT Working Paper 29)

VANHAVERBEKE, W. Realizing new regional core competence: establishing a customer-oriented SME-network. Disponível em:

<http://netec.wustl.edu/WoPEC/data/Papers/dgrumanib1999903.html > Acesso em:7 jun. 1999.

VEIGA, J.E. A face territorial do desenvolvimento. Disponível em:

<http://www.ipea.gov.br/redepesq/produtos/trabalhos/economia_regional1/JEVeiga. $\underline{\mathrm{html}}$. . Acesso em: 29 jun.2001.

WHAT is a cluster? Regional clusters: some definitions reference. About Competitiveness. Disponível em:

<http://www.competitiveness.org/about/about.htm> Acesso em: 18 jan. 2000.

WILLIANSON, O.E. Transaction cost economics. In: The economic institutions of capitalism :firms, markets, relational contracting. New York: Free Press, 1987. p.15-42.

WORLD BANK. What is social capital? Disponível em: <http://www.worldbank.org/poverty/scapital/whatsc.htm> Acesso em: 20 set. 2002. 
